\title{
ASK THE AUDIENCE: THE ROLE OF TECHNOLOGY IN STUDENTS' UNIVERSITY EDUCATION
}

\author{
By, \\ Erin L. Murphy \\ A thesis submitted to the Department of Sociology and Anthropology \\ in partial fulfillment of the requirements for the degree of \\ Master of Arts in Sociology \\ to \\ The Faculty of Graduate Studies and Research \\ Department of Sociology and Anthropology \\ Carleton University \\ Ottawa, Canada \\ May, 2010
}

CCopyright 2010, Erin L. Murphy 


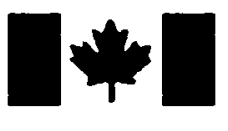

Library and Archives
Canada

Published Heritage Branch

395 Wellington Street

Ottawa ON K1A ON4

Canada
Bibliothèque et

Archives Canada

Direction du

Patrimoine de l'édition

395 , rue Wellington

Ottawa ON K1A ON4

Canada
Your file Votre référence
ISBN: $978-0-494-68690-4$
Our file Notre référence
ISBN: $978-0-494-68690-4$
NOTICE:

The author has granted a nonexclusive license allowing Library and Archives Canada to reproduce, publish, archive, preserve, conserve, communicate to the public by telecommunication or on the Internet, loan, distribute and sell theses worldwide, for commercial or noncommercial purposes, in microform, paper, electronic and/or any other formats.

The author retains copyright ownership and moral rights in this thesis. Neither the thesis nor substantial extracts from it may be printed or otherwise reproduced without the author's permission.
AVIS:

L'auteur a accordé une licence non exclusive permettant à la Bibliothèque et Archives Canada de reproduire, publier, archiver, sauvegarder, conserver, transmettre au public par télécommunication ou par l'Internet, prêter, distribuer et vendre des thèses partout dans le monde, à des fins commerciales ou autres, sur support microforme, papier, électronique et/ou autres formats.

L'auteur conserve la propriété du droit d'auteur et des droits moraux qui protège cette thèse. $\mathrm{Ni}$ la thèse ni des extraits substantiels de celle-ci ne doivent être imprimés ou autrement reproduits sans son autorisation.
In compliance with the Canadian Privacy Act some supporting forms may have been removed from this thesis.

While these forms may be included in the document page count, their removal does not represent any loss of content from the thesis.
Conformément à la loi canadienne sur la protection de la vie privée, quelques formulaires secondaires ont été enlevés de cette thèse.

Bien que ces formulaires aient inclus dans la pagination, il n'y aura aucun contenu manquant.

\section{Canadä}




\begin{abstract}
Digital technologies are unavoidable features of daily life. As a result, theorists have suggested the omnipresence of digital technologies has profoundly influenced the lives of youth to the point where they can be defined by their use of digital technologies. The terms used to define youth include "digital natives" (Prensky 2001a), and the "net generation" (Tapscott 1998). These theorists further argue that the education system is unequipped to meet the needs of students, and both teaching practices and content need to be adapted for the digital age. The current research interrogates this characterization of youth by asking the question: does the characterization of youth as digital natives apply to young peoples' expectations and experience of education? A mixed methods approach is used to collect data from surveys, interviews, and observations. The research findings suggest that students demonstrate a complex relationship with digital technology, especially in regards to their classroom experiences.
\end{abstract}




\section{Acknowledgements}

First, I must thank my supervisor, Dr. Janet Siltanen, without whose guidance and support this research would not have been possible, and my committee member, Dr. Carols Novas, for his insight throughout the process of my research. Thanks also to the students and professors who took the time to participate in my research. I am also grateful to the Social Science and Humanities Research Council and the Ontario Graduate Scholarship for providing funding that afforded me the ability to focus solely on my courses and research for the past two years.

I also want to thank my friends for reminding me to take breaks and for knowing not to ask how my research was going. My gratitude also to the McMahons for all of the dinner invites and delicious meals. Lastly, and most importantly, I am grateful to my parents for always encouraging, and being proud of, me. My successes are your successes. 


\section{Table of Contents}

Abstract

Acknowledgements iii

Table of Contents iv

List of Tables vi vi

List of Illustrations vi

List of Figures vi vi

Chapter 1: Youth, Technology, and Education 1

"Digital Natives" and the "Net Generation" 3

The Digital Native Debate $\quad 7$

Why Clickers and Laptops? 11

Chapter Outline $\quad 26$

Chapter 2: Methodology 28

Using Mixed Methods 29

Participants $\quad 32$

Data Sources $\quad 34$

Ethics $\quad 39$

Research Process 40

Data Analysis Strategy $\quad 43$

Methodological Reflection and Assessment $\quad 47$

$\begin{array}{ll}\text { Summary } & 49\end{array}$

Chapter 3: Digitally Mediated Interaction 51

The Presence of Clickers and Clicker Questions 53

Students' In-class Participation and Involvement 65

$\begin{array}{ll}\text { Technological Discourse } & 74\end{array}$

$\begin{array}{ll}\text { Summary } & 84\end{array}$

Chapter 4: Digital Notepads or Mobile Distractions? 88

Bringing Laptops to Class 90

In-class Laptop Activities $\quad 92$

Laptops and Wireless Internet in the Classroom 96

What is Going on Behind the Screen? 100

$\begin{array}{ll}\text { Summary } & 103\end{array}$

Chapter 5: Digital Technologies and Educational Expectations 106

$\begin{array}{ll}\text { Digital Classrooms for Digital Natives } & 107\end{array}$

$\begin{array}{ll}\text { Ubiquitous Personal Technologies } & 108\end{array}$

Skills, Capacities, and Technologies 112

Digitally Enhanced Classrooms?

$\begin{array}{lr}\text { Summary } & 126\end{array}$ 
Chapter 6: The Complex Role of Technology in University Education

The Digital Native Debate

Interactivity and Collaboration $\quad 134$

Comfort With Technology 136

'Play' versus 'Work'

138

Research Contributions

139

Future Research

Appendix A: Letters of Information and Consent

Appendix B: Clicker and Laptop Surveys

Appendix C: Clicker Interview Questions 


\section{List of Tables}

4.1 Laptop Activities 92

5.1 Amount of Technology in the Classroom 123

5.2 Classroom Activities 125

\section{List of Illustrations}

3.1 Sample Business Class Clicker Slide 55

3.2 Sample Science Class Clicker Slide 55

\section{List of Figures}

$\begin{array}{ll}3.1 & \text { Understanding }\end{array}$

3.2 Disruption $\quad 62$

3.3 Participation 68

$\begin{array}{ll}3.4 & \text { Involvement } \\ 3 & 71\end{array}$

3.5 The Clicker System 80

5.1 Importance of Technology 114

$\begin{array}{lll}5.2 & \text { Skills and Technology } & 121\end{array}$ 


\section{Chapter 1 \\ Youth, Technology, and Education}

According to some theorists, the distinguishing feature of youth today is that they have grown up in the digital age, surrounded by digital technologies. These can be physical technologies such as computers, cell phones, and $\mathrm{mp} 3$ players, or they can be information and communication technologies (ICTs) made available through the Internet, such as e-mail and social networking sites. Such technologies both identify a distinctive element in the experiences of contemporary young people, and are argued to construct a way of being that sets them apart from previous generations. Prominent examples of how the current generation of youth is identified include 'digital natives' (Prensky 2001a), and the 'net generation' (Tapscott 1998).

The present research on youth, technology and education is framed by, and simultaneously interrogates, the 'digital native' characterization of today's youth. Marc Prensky (2001a), the e-learning expert credited with coining the 'digital native' term, argues that people born since the early 1980 s should be thought of as digital natives because they have grown up with digital technologies, most notably the Internet. Similarly, business strategist Don Tapscott (1998) uses the term 'net generation' to refer to this group (though he includes those born between 1977 and 1997), and between his two books, Growing Up Digital (1998) and Grown Up Digital (2009), he traces the development of this new generation. 
Both authors premise their arguments on the understanding that today's youth are fundamentally different from their predecessors. Prensky (2001a:1) argues that, "a really big discontinuity has taken place" and "this so-called 'singularity' is the arrival and rapid dissemination of digital technology in the last decades of the twentieth century". Similarly, in the introduction to Growing Up Digital, Tapscott (1998:1-2) notes that because the members of the net generation have grown up surrounded by digital technologies, "for the first time in history, children are more comfortable, knowledgeable and literate than their parents about an innovation central to society". Palfrey and Gasser (2008:2) echo this sentiment by noting that, "Major aspects of their lives - social interactions, friendships, civic activities - are mediated by digital technologies. And they've never known any other way of life". All of these authors argue that the arrival of digital technologies over the last thirty years has consolidated so that we now live in a 'digital world'. Such a world is identified as involving a profound shift in how everyday life is experienced.

The characterizations of today's youth as digital natives and the net generation have become widely discussed and utilized - particularly in the key area of education. Prensky (2001a:1) notes that, "Today's students are no longer the people our education system was designed to teach". And both Prensky and Tapscott (neither of whom are members of the 'net generation'), argue that digital native students' educational needs and potential are not being met by the current education system. As a result, they assert that educators and administrators 
need to change their practices to better serve this new generation of students (Prensky 2001a, Tapscott 2009).

By presenting empirical data that contributes a more nuanced understanding of the role of technology in the lives of youth, this research interrogates the characterization of today's students as 'digital natives' and in particular interrogates the claim that the current generation of young people requires a more technologically driven classroom. This characterization is assessed from a sociological perspective by examining how young people experience university education, and especially how they characterize their own relation to technology in the classroom. The question being asked through this research is: does the characterization of youth as digital natives apply to young peoples' expectations and experience of education? However, before this question can be answered, a better understanding of the digital native argument needs to be developed.

\section{"Digital Natives" and the "Net Generation"}

There are a number of common traits identified by Prensky (2001a) and Tapscott (2009) in their respective descriptions of digital natives and the net generation. They suggest digital natives desire speed in everything they do, like random access and customization, thrive when networked or collaborating, and want everything they do to be fun and entertaining. Both authors argue that these traits - speed, customization, collaboration, and entertainment - should be taken into account by educators and administrators when designing and delivering curricula to digital natives. 
Prensky (2001a:1) uses the term 'digital native' because "students today are all 'native speakers' of the digital language of computers, video games and the Internet". In addition to this, Prensky describes those who came before the digital datives - their parents and teachers - as 'digital immigrants' because they are non-native speakers of the new digital language who have had to adapt to a new digital world. According to Prensky (2001a:3) the disconnect between digital native students and digital immigrant educators is the "...single biggest problem facing education today...". Prensky's (2001a:4) solution is for digital immigrant educators to adapt their teaching methods and content to meet the new needs of today's students because "no matter how much the immigrants may wish it, it is highly unlikely the digital natives will go backwards". This description devalues educators while simultaneously empowering students. While Prensky focuses his attention on students and educators, Tapscott's two books look at all aspects of what he refers to as the 'net generation' from play, to school to work.

In addition to the common characteristics listed above, Tapscott outlines what he identifies as the ten themes of ' $\mathrm{N}$-Gen' culture in his first book. These themes include 'fierce independence', 'emotional and intellectual openness', 'inclusion', 'free expression and strong views', 'innovation', 'preoccupation with maturity', 'investigation', 'immediacy', 'sensitivity to corporate interests', and finally, 'authentication and trust' (Tapscott 1998 68-77). Together, these ten themes are claimed to define today's youth culture and shape all aspects of their lives, including education. 
"Interactive" Students in "Broadcast" Classrooms

Along with outlining the characteristics of digital natives and the net generation, both Prensky (2006) and Tapscott (2009) make suggestions for how educators can succeed in the digital age. In his 2006 article "Listen to the Natives", Prensky makes a number of suggestions as to how educators can best support digital native students. He argues that today's educators need to put engagement before content and collaborate with their students, both as individuals and in group settings. He further asserts that educators need to allow for flexibility and student choice, harness the capabilities of digital tools such as cell phones, and encourage students' programming skills. Finally, Prensky recommends that educators focus on " $21^{\text {st }}$ century subject matter" and make school more like after-school in terms of the types of activities that students engage in.

In terms of teaching methods, Prensky (2001a) says that educators need to learn to be faster and less linear when teaching because these are features that today's students are accustomed to, especially from their time spent playing video games. Prensky (2001a) continues his recommendations by making the distinction between 'legacy' and 'future' content. According to Prensky, legacy content refers to the 'traditional' curricula of "reading, writing, arithmetic, logical thinking, [and] understanding the writings and ideas of the past". 'Future', or ' $21^{\text {st }}$ century' content on the other hand, is "digital and technological" and includes "software, hardware, robotics, nanotechnology, genomics, etc. [but] it also includes the ethics, politics, sociology, languages, and other things that go with 
them." (Prensky 2001a:4-5, 2006). In other words, curriculum should combine both legacy and future content that is designed around utilizing digital technologies and preparing students for success in the digital world. Considering Prensky's argument, significant changes need to be made to both methodology and content in order to better serve digital native learners.

Many of Tapscott's (2009) suggestions echo those of Prensky. Tapscott first recommends that the education system needs to become less of a 'broadcast' model where educators lecture and students listen, and become more of an 'interactive' model which is similar to what students are used to in their digital lives (1998:143). To do this, educators should focus on pedagogy when introducing technology into the classroom. Similar to this, Palfrey and Gasser (2008) agree with the digital native characterization of today's youth and agree that technologies should be harnessed to assist today's students with their educational pursuits, as long as they are pedagogically supported and not introduced for the sake of technology.

Tapscott (2009) further suggests that educators should lecture less and interact with students more, and should encourage students to collaborate both with each other and with experts. Additionally, educators should focus on teaching students how to learn so that they can engage in life-long learning, and should allow students to customize their learning (Tapscott 2009). Ultimately, what both Prensky $(2001 \mathrm{a}, 2006)$ and Tapscott $(1998,2009)$ argue is that today's students need to be given much more control over their education, and that technology is an integral part of making this happen. 


\section{The Digital Native Debate}

While the digital native and net generation characterizations of today's youth have become accepted and utilized in areas such as education, there have also been some critiques. These critiques suggest that digital native theory is technologically deterministic and that more empirical research needs to be done to attempt to better understand the role of technology in the lives of today's youth. The current research aims to further contribute to this critical literature.

Selwyn's (2009) review of literature in the areas of education studies, information sciences, and media studies, argues that the digital native portrayal of young people should be seen as a mostly inaccurate and over-simplified discourse rather than an empirically supported description. Selwyn proposes that:

whilst the past ten years have undoubtedly witnessed significant changes in the technological practices and predilections of children, young people and young adults, it would seem sensible to reconsider the status of the "digital native" description as a prima facie account of young people's lives in the early twentyfirst century. (2009:366)

Selwyn makes the argument that the digital native characterization is too technologically deterministic and that young people today have a much more complex relationship with technology than the digital native discourse would suggest. In light of this, he recommends that empirical social scientific research on youth and technology should be undertaken to reconsider the digital native characterization.

Further to Selwyn's argument, Sheely (2008) uses Latour's approach to the sociology of knowledge to highlight the constructed and discursive features of the digital native characterization. Sheely traces the use of the digital native 
discourse from its origin by Prensky to its use in disciplinary and public discourses, in order to demonstrate how the characterization has moved from an individual's idea to an accepted fact. Sheely demonstrates how the digital native characterization quickly moved from being a cited idea to a stabilized, taken-forgranted, common sense term. After questioning its very basis, Sheely (2008:914) ultimately refers to Prensky's 'digital native' as an "illusion" but argues that it is an important illusion insofar as it leads to questions and discussions about students' learning needs.

Bennett, Maton and Kervin (2008) also call for a critical consideration of the very existence of 'digital natives'. They note that there is almost no empirical or theoretical evidence to support the characterization of today's students as digital natives and that the popularity of the 'digital native' is largely a result of its appeal to common sense. Drawing on educational research and writings on the sociology of knowledge, Bennett et al. (2008) conceptualize the digital native debate as the academic equivalent of Cohen's moral panic in that the 'threat' presented by digital natives to the education system is likely being blown out of proportion. Digital native theorists such as Prensky, use the 'threat' of the digital native student to advocate for system-wide, technologically-enhanced changes to the education system. Bennett et al. (2008) see the digital native debate as a stalemate until more empirical evidence, including accounts of youth and instructors, is provided. Furthermore, these authors suggest that based on the little empirical research that has been done, it is possible that the within-group 
differences of young people today, may be of more importance to educators than their similarities.

Similarly, Bayne and Ross (2007) argue that the discussion around 'digital natives' and 'digital immigrants' is a problematic discourse that needs to be considered much more critically. They argue against the 'digital immigrant' characterization of educators as subordinates who need, but are unable, to change, because it places educators in an impossible position. These authors also assert that the 'need' to change the education system is often spoken of in terms of meeting student 'needs', but is actually a means of promoting a commodified vision of education. Bayne and Ross (2007) also express concern over the use of a native/immigrant metaphor which they argue is racialized and inherently problematic.

Toledo (2007) also identifies problems with the characterization of educators as digital immigrants and argues that the native/immigrant dichotomy is too simplistic as a model of today's students and educators. Toledo suggests that a third characterization - the digital tourist - be included, and that the model should be thought of as a continuum rather than a dichotomy. According to Toledo (2007), a digital tourist is someone who maintains a more distant relationship to digital technologies and only uses them when necessary. Toledo asserts that this is a better description of many educators than the digital immigrant who is unable to use digital technologies. Toledo concludes by making a series of suggestions for how educators can move from the 'print world' to the 'digital world' (2007:90). Some of these suggestions include switching from 
lecturing to podcasts or webcasts, having students submit electronic assignments, and using online tests and quizzes. While Toledo has a problem with the details of the native/immigrant characterization she is not wholly opposed to it. By suggesting the digital tourist and making recommendations for how educators can adapt to the digital age, Toledo is implicitly supporting the digital native argument.

Further in line with Bennett et al.'s argument, Jones, Ramanau, Cross, and Healing's (2010) study of first year university students' experiences with elearning at five universities in England, uncovers a number of differences within the so-called net generation. Through a survey, these researchers collected basic demographics, information on students' access to various technologies, and students' study-related and course-specific technology use. In terms of access to technology, this research found that the majority of students involved own cell phones, mp3 players and laptops. Jones et al. (2010) also found many withingroup differences in terms of participants' use of web 2.0 technologies such as social networking sites, blogs, and wikis. Students also demonstrated variation when asked about their confidence and skills level with education-related technologies such as spreadsheets, presentation software, and online library resources. Ultimately, Jones et al. (2010) claim that the digital native characterization of students should be approached with caution because while there are some age-related differences present, today's youth are far from being a homogenous generation. 
Furthermore, while they do not use the terms 'digital native' and 'digital immigrant', authors Dutton and Loader (2002) do identify a numer of problems with this characterization. They note that it is important to have a solid understanding of the audience - students in the case of university education when implementing the use of new technologies. Additionally, Dutton and Loader (2002) argue that it should not be assumed that all students are natives and all educators immigrants because these characterizations are often unrepresentative.

What is clear through this literature is that while the digital native characterization has become accepted as a common sense understanding of today's youth, it is actually a highly contested term. It is also clear that while attention has be paid to critically examining the digital native discourse, very little has been done to conduct empirical research on the relationship between youth, technology, and university education. The present study aims to contribute to this need for empirical research by investigating the use of technology in undergraduate classrooms. Because classroom technologies are diverse, the research focuses on a technology that is introduced into undergraduate classrooms by professors - clickers - and a technology brought into classrooms by students - laptops.

\section{Why Clickers and Laptops?}

Technology is not new to the university classroom. From chalk and blackboards, to slide and overhead projectors, technologies have always been available to professors to assist them with presenting their lectures. However, 
what is different about more recent technologies that have made their way into university classrooms, is that they are predominantly digital and are increasingly being used by students. This is happening in two ways - students are, in large numbers, bringing personal technologies such as cell phones and laptops into the classroom, and institutions and educators are simultaneously introducing interactive technologies into classrooms. Both are creating technology-mediated learning environments for today's students. Technology-mediated meaning either, that interaction between students and professors is taking place through the use of technology, or that it is being hindered by it.

One the most obvious examples of the way students are bringing technology into the classroom is the ever-growing number of laptops that are now present in many university classrooms. Meanwhile, a prime example of the way in which institutions and educators are introducing technology into the undergraduate classroom is through the use of Audience Response Systems, more commonly known as 'clickers'. Probably best known for their use in the 'ask the audience' lifeline on the game show Who Wants to be a Millionaire, clickers are becoming increasingly common in university classrooms. This research utilizes clickers and laptops as exemplars of instructor-introduced and studentintroduced classroom technologies.

Clickers represent a technology that is brought into the classroom, and controlled by the professor, while laptops represent a technology that is brought in, and controlled by, individual students ${ }^{1}$. Additionally, clickers are used for

\footnotetext{
1 It is important to note that laptops can also be provided by the university, but that did not appear to be the case in any of the classes participating in this research.
} 
purely academic purposes, while laptops can be used for both academic, and a variety of non-academic activities. Furthermore, clickers are used as a means of engaging and including students in the class, while laptops can be used by students to either engage with, or disengage from the lecture. What these contrasts demonstrate is that there are various ways in which digital technologies can be present in a classroom setting. By looking at both of these technologies the hope is that a clear picture of how today's youth conceptualize the role of technology in their education will begin to emerge.

\section{Clickers}

The academic literature on clickers is limited. Most of what is available is simply the result of instructors reporting on their individual experiences with the technology. Despite the limited research, there are some interesting themes and findings, as well as methodological suggestions found within this literature. Both the pedagogical benefits and challenges of using clickers are emphasized by the existing research.

Kay and LeSage (2009) provide a comprehensive overview of research that has been done on clickers beginning with a brief history of the technology. These authors note that clickers were first introduced at Stanford University in 1966 though these early models did not work very well. Through various developments in the technology over the next thirty years, affordable infrared clickers became available in 1999, and have been in common use in the American education system since 2003 (Kay and LeSage 2009). 
These authors also identify twenty-six different terms for clickers including ‘audience response system', 'personal response system', ‘electronic voting system', and 'student response system', amongst others (Kay and LeSage 2009:820). The colloquial 'clickers' is employed for the purposes of the current study because it is the term used by everyone encountered in the process of conducting this research. TurningPoint, the company that makes the devices and software that this thesis focuses on also use the term audience response system.

\section{Benefits of Using Clickers}

In their case study on the use of clickers in university library information sessions at Texas A\&M, Hoffman and Goodwin (2006) identify six benefits to using clickers. First, they found that clickers help to ensure interaction. Secondly, clicker questions help keep students focused by re-attracting their attention with each new question. This benefit was also reported by the students in King and Robinson's (2009) study of the use of clickers in mathematics classes at Loughborough University. Kay and LeSage's (2009:821) literature review also found significant support for clicker questions increasing students' attention, especially when clicker questions are used every twenty minutes.

Thirdly, Hoffman and Goodwin (2006) found that the anonymous use of clickers helps to increase participation. This was supported by Cutrim Schmid's (2008) finding that using clickers anonymously meant that students did not have to be embarrassed about answering incorrectly. Fourth, clicker questions lead to more class discussion than the researchers had experienced when giving the same presentation without clickers. This was especially true when the clicker 
question includes 'other' as a response option. These researchers also found that clicker questions lead to an increase in the number of questions from students (Hoffman and Goodwin 2006). An increase in discussion and various forms of interaction in classes using clickers was also identified by the majority of the studies reviewed by Kay and LeSage (2009). Hoffman and Goodwin (2006) also noted that the use of clicker questions leads to increased retention of information by students.

Lastly, Hoffman and Goodwin (2006) noted that both students and instructors find clickers fun to use. Again this finding is supported by the student feedback reported by Cutrim Schmid (2008). The fun factor was also supported by Jones et al. (2009) who suggest that clickers should be used to make learning more enjoyable. When presented with a list of seven attributes of clicker use and asked to rank the top three, 'it is fun' was ranked last (seventh) by the students in King and Robinson's study of clickers in math classes, but the researchers suggest that this may be because students are taught to take a "serious and disciplined approach to learning" and may not associate classroom learning with fun (2009:193).

Beyond these six benefits outlined by Hoffman and Goodwin, a number of additional benefits to using clickers have been identified in additional research. In the extensive literature review conducted by Kay and LeSage (2009), the majority of the studies reviewed reported that students found it easy to learn how to use clickers. Furthermore, Cutrim Schmid (2008) reports benefits including a greater sense of ownership over one's learning and a more student-centred approach to 
learning, while $80 \%$ of the students in King and Robinson's (2009:194) study said that clickers were "useful".

Kay and LeSage (2009) also found that classroom attendance was positively affected by the presence of clickers when a portion of the course grade was based on clicker participation. They note however that while attendance increased when it could be tracked by clicker use, students were not generally supportive of this practice. Many of the studies in Kay and LeSage's (2009) review found that clickers increased student engagement in class though Kay and LeSage note that it is not clear why this is the case. Kay and LeSage (2009) suggest that it could be due to the active component of using clickers, or simply because they are fun to use. Kay and LeSage's (2009) review also found that in many studies, clickers have been found to improve learning performance and quality when compared to classes not using clickers, though it is not identified how these comparisons were established.

Many researchers found pedagogical support for the use of clickers. In their article that focused on pedagogical reasons for using clickers, Jones et al. (2009) based their discussion on Chickering and Gamson's (1987) Seven Principles for Good Practice in Undergraduate Education. The first principle for good practice identified by Chickering and Gamson (1987) is "student-faculty contact". Jones et al. (2009) found that this can be encouraged through discussion that takes place after clicker questions. Additionally, Hoffman and Goodwin (2006:430) found that in their study, clickers acted as an "ice-breaker" by giving students and instructors something to talk about before the lesson even 
began. Mayer et al. (2009) also found that clicker questions help to encourage student-instructor interaction throughout a lecture.

Chickering and Gamson's (1987) second principle is to encourage "cooperation among students". Jones et al. (2009) suggest that this can be achieved by putting students into groups to answer clicker questions. Additionally, through a series of interviews with her students, Cutrim Schmid (2008) found that students would have liked the opportunity to discuss the options with each other before answering clicker questions. Hoffman and Goodwin (2006) also suggest that by putting students into groups who 'compete' against each other, cooperative learning can be encouraged. Kay and LeSage's (2009) review also found some evidence to suggest that students like to see how their peers are doing in the class.

The third principle outlined by Chickering and Gamson (1987) is to promote "active learning". Through the use of questionnaires and interviews that were given to students in a class using clickers in conjunction with an Interactive White Board, Curtrim Schmid (2008) found that students associated their use of clickers with increased student interactivity and active participation. This was in part due to the clicker questions helping students to pay attention. In addition, some students noted that clickers created 'forced participation', but this was generally seen as a benefit, especially by students who said they would not have participated otherwise (Cutrim Schmid 2008). In relation to active participation and learning, Hoffman and Goodwin (2006) suggest that instructors can use clicker systems to turn their classroom into a game show setting. The anonymity 
provided by clickers was also found to increase the level of student participation in Cutrim Schmid's (2008), and King and Robinson's (2009) studies. The benefit of anonymous participation was also emphasized by many of the studies in Kay and LeSage's (2009) review.

Chickering and Gamson's (1987) fourth principle is to provide students with "prompt feedback". In support of this, Cutrim Schmid (2008) noted that clicker answers are instantaneous, while Jones et al. (2009) noted that clickers provide immediate feedback to both students and the instructor. Clickers allow students to see how they are doing in the class in relation to their fellow students, and instructors are able to see how the class is doing as a whole (Jones et al. 2009). The clicker system's ability to provide students with feedback was also supported by King and Robinson's findings (2009). Through the use of a questionnaire, these researchers found that students ranked various aspects of feedback - 'checking understanding' and 'identifying problem areas' - as two of the most important benefits of clickers. Kay and LeSage's (2009) literature review found that the ability of clicker systems to provide instant feedback led to more contingent teaching in that instructors were able to adapt their lessons on the spot based on the results of clicker questions.

The fifth principle presented by Chickering and Gamson (1987) is that good practice "emphasizes time on task". Jones et al. (2009) note that clickers can help to achieve this goal by letting the instructor gauge how well students understand a particular topic. This can give instructors a sense of how much time they should devote to topics depending on how well their students are doing. 
Chickering and Gamson's (1987) sixth principle is that good practice "communicates high expectations". The authors note that high expectations are an important motivator for many students. Interestingly, although this pedagogical principle is mentioned by Jones et al. (2009), they do not have any suggestions as to how this can be achieved through the use of clickers. The final principle outlined by Chickering and Gamson (1987) is that good practice "respects diverse talents and ways of learning". Jones et al. (2009) suggest that the very presence of clickers introduces a new way of learning and that students seem to respond favourably to their introduction into the classroom.

\section{Challenges of Using Clickers}

In addition to the six benefits of using clickers as identified by Hoffman and Goodwin (2006:431), these researchers identified three challenges. First, they noted that like any technologies, the clicker system can experience "hiccups" and they recommend that back-up plans should be in place in case problems arise. In King and Robinson's (2009) study, seventy-eight of the one hundred and fortyfive students who took part noted that at some point their clicker did not work. The challenge of the clicker system not working was also identified by a number of the studies reviewed by Kay and LeSage (2009), who also found that students not bringing their clickers to class was reported as a challenge.

Secondly, Hoffman and Goodwin (2006) found that there can be more time needed when preparing lessons that involve the use of clickers. This is especially true when first learning how to use the system. They also note that it can take time to develop effective clicker questions. King and Robinson (2009) found that 
in their research, forty-two of the one hundred and forty-five students reported the time it takes to set up the clicker system as a drawback to using clickers. Lastly, Hoffman and Goodwin (2006) found that the clicker system is not very portable because of the need for the software to be installed on all instructor computers. Despite the challenges and drawbacks however, both Hoffman and Goodwin (2006), and King and Robinson (2009) concluded that the benefits of clickers strongly outweighed the challenges they experienced.

Kay and LeSage's (2009:823-825) in-depth literature review identified both teacher-centred and student-centred challenges to using clickers. Inability to respond to the results of clicker questions, covering less material, and trouble designing clicker questions were all found to be teacher-centred challenges. Trouble adapting to a new learning method, distraction by the use of clickers, exerting more "cognitive energy" by having to engage with questions instead of passively listening to a lecture, covering less material, confusion in discussions, and being monitored were all determined to be student-centred clicker challenges.

A number of pedagogical challenges were also identified throughout the existing clicker research. Cutrim Schmid (2008) found that students saw the ability to guess the correct answer to be a downside of the clicker system. The ability to guess without consequence meant that students did not have to be sure of their responses and therefore may not be very engaged with the lecture materials. This was found to be a detriment to the remediation process following the clicker questions because students did not always engage in the level of in- 
depth discussion the instructor was hoping for (Cutrim Schmid 2008). King and Robinson (2009:194) also found that some students identified "guesswork" as a drawback to the clicker system.

Jones et al. (2009) raise some concerns about students being able to cheat while using clickers. These authors made suggestions about how students can shield their peers from seeing how they are voting. They also suggested that students should not be allowed to discuss answers prior to voting unless peer learning is a stated goal. This goes against Cutrim Schmid's (2008) finding that students want to be allowed to discuss answers prior to voting.

Based on findings from interviews with her students Cutrim Schmid (2008) made three recommendations for pedagogical implications of using clickers. First, she found that there were a couple of ways to deal with the problem of students guessing on clicker questions. Students should be provided with an II don't know' option on all clicker questions and should be informed that selecting 'I don't know' is helpful when they really are unsure of the correct answer (Wit 2003 as cited in Cutrim Schmid 2008). As mentioned above, some of her students suggested that it would be helpful to allow students to discuss the options with their classmates before clicking in an answer, thus allowing them to be more confident in their response (Cutrim Schmid 2008). Secondly, the author found that more attention needs to be paid to combining the use of clickers with followup or debriefing and class discussion. Lastly, Cutrim Schmid (2008) suggested that more effort should be made to allow students to participate in their learning by allowing them to design clicker questions. 
While there are some challenges identified, the research on clickers is generally in favour of their use. Many pedagogical benefits have been established and supported by this research, and clickers appear to be well received by both students and educators. However, while clickers and laptops both represent digital technologies that are becoming increasingly common in undergraduate classrooms, the similarities end there.

\section{Laptops}

Very little academic research has been done on student use of personal laptops in a classroom setting. The research that does exist on laptops in postsecondary classrooms predominantly pertains to the success or failure of ‘ubiquitous computing' initiatives which are institution-implemented programs to provide all of their students with laptops. There are findings in this research however, that are applicable to the current study.

McMahon and Pospisil (2005) conducted a study entitled Laptops for a Digital Lifestyle, in which they sought to better understand how 'millennial' students use laptops in their school, social, and work lives. This study surveyed a group of undergraduate students about their use of, and attitude towards, laptops. The students in their study said that around-the-clock Internet access was very important to them because the Internet is their primary source of information.

In addition to wanting Internet access, the students in this project said that they appreciated the flexibility that the mobility of their laptops afforded them and that they liked being able to use them whenever and where ever they wanted to 
(McMahon and Pospisil 2005). Ultimately, their study found that students' attitudes toward, and use of laptops supported their being characterized as 'millennials'. The students in this study desired $24 / 7$ Internet access, connectivity and immediacy (McMahon and Pospisil 2005).

Lindroth and Bergquist (2010) conducted an ethnographic study of students' laptop use focusing on what constitutes competent laptop use in a lecture setting. Importantly, this research took place at an IT-University where most students have laptops. They use the term "laptoper" to refer to a student with a laptop, and the term "laptoping" to refer to the use of said laptop. They stress that what counts as competent laptoping in educational practice varies by individual student (Lindroth and Bergquist 2010).

Lindroth and Bergquist (2010) divide students' in-lecture activities between dominant and subordinate involvements. They found that students consider listening to the lecture to be the dominant involvement but that they find it acceptable to use their laptops for subordinate activities if they find the lecture boring. Since listening to the lecture is the dominant involvement, any other activity - including note taking - is considered subordinate because it draws attention away from the lecture, though these activities can still be related to learning. Subordinate activities that were found to support the dominant involvement of listening to the lecture included searching the Internet for information related to the lecture, taking notes, and communicating with fellow students via instant messaging to ask questions or share notes and resources (Lindroth and Bergquist 2010:318). There were also subordinate activities that 
did not support listening to the lecture because they were more for entertainment purposes such as watching funny videos (Lindroth and Bergquist 2010). These authors found that this entertainment activity could spread to other students because of the visibility of computer screens.

Lindroth and Bergquist (2010:319) conclude their study with a discussion of the five characteristics of laptopers. They found that students have to be more responsible for their own learning in terms of deciding what is appropriate when using a laptop in class. They also found that students need to develop skills that include knowing how to minimize the distraction from their laptops while also knowing how to use it to enhance their learning. Thirdly, these authors found that the mobile nature of laptops means that the learning situation can be extended beyond the classroom. They also found that laptops create competition for the lecturer and that lecturers should therefore consider incorporating laptops into their teaching designs. And lastly, they found that there are a number of physical distractions caused by laptops such as sounds and lights and that the ways in which students deal with these distractions should be further investigated.

Fried (2008) conducted a study on student laptop use in a class where all students had laptops and were free to bring them to class as they pleased. The aim of the study was to understand the relationship between student laptop use and their learning. Students were surveyed weekly on various aspects of the class including their laptop use. The survey asked students what they did with their laptops while in class and included the options of note taking, checking email, sending instant messages, surfing the Internet, playing games, and other 
(Fried 2008:909). Of the students who completed the surveys, $64.3 \%$ said that they used their laptop in class at least once. Of these students, $81 \%$ said they checked their e-mail, $68 \%$ used instant messaging while in class, $43 \%$ surfed the Internet, 25\% played games, and 35\% engaged in 'other' activities (Fried 2008: 910).

Students were also asked to report on distractors in the class, and 'other students' laptop use' was most commonly reported. Using students' results on formal tests as a measure of aptitude, Fried compared student laptop use with their scores on these tests and their class attendance to determine the impact of laptops on the students' learning in the course. It was found that the more students use their laptops in class, the worse their class performance was (Fired 2008: 910). Laptops were found to have significant negative effects on student learning when they are used in uncontrolled settings.

In contrast to clickers, the existing research on laptops is less favourable. Laptops appear to be distracting both to their owner and the students around them, and do not seem to offer pedagogical benefits when their use is uncontrolled and unrelated to the lecture. Despite this, students seem to want the option to bring laptops with them into their classrooms.

The research on clickers and laptops is limited and more needs to be done to hear from students about the role of these technologies in their classrooms. The remainder of the current research addresses this need, while also investigating the relationship between technology and education more broadly. 
The investigation of the use of clickers and laptops serve as an entrance into a critical consideration of the digital native characterization of today's youth.

\section{Chapter Outline}

Chapter two outlines the methodological and ethical considerations of this research. It begins with a discussion of the mixed methods approach used to combine surveys, interviews, and observations as data collection strategies. Chapter two also includes a consideration of the data sources and the methods of analysis employed in this research. The methodology chapter concludes with a critical assessment of the methodologies used throughout the research.

Chapter three describes the findings of the research associated with the use of clickers in university classrooms. The results of the unobtrusive observations of two clicker-enabled classes are incorporated with the results of the student surveys and the professor interviews, to begin to paint the picture of how today's youth view technology in relation to their education. The results of this chapter provide support for the use of instructor-controlled technology in undergraduate classrooms, and for the characterization of today's youth as digital natives. Clickers are compatible with the portrayal of digital natives as people who crave instant gratification, entertainment and collaboration.

Chapter four focuses on the results of the laptop survey that was presented to two large, introductory classes and begins to complicate the understanding of today's students as digital natives. This chapter demonstrates that the type and frequency of laptop use varies greatly amongst students. The findings in this chapter also suggest that students desire wireless Internet access 
and the freedom to bring their laptops to class, and appear to multi-task which are in line with the digital native characteristic, but as this chapter demonstrates, they do not necessarily want their personal digital technologies to be incorporated into formal classroom proceedings.

Chapter five further complicates the understanding of the role of technology in university classrooms by presenting the results of the survey questions on educational expectations and personal technologies. While their ownership of personal technologies and their comfort level with technology suggest that today's youth are in fact digital natives, their opinions on the use of technology within the classroom are not as supportive of this characterization. This chapter demonstrates that today's youth desire only a moderate amount of technology to be incorporated into the classroom and that they are largely in favour of more socially mediated classroom activities such as more lecture and review, and small group work with their peers.

The final chapter reflects on the research findings by looking at how they both support and question some of the digital native characteristics outlined by Prensky and Tapscott. In particular, chapter six discusses the research findings that relate to three digital native themes including the desire for interactivity and collaboration, comfort with the use of technology, and the presence of a play/ work dichotomy. The closing chapter also discusses the contributions made by this thesis and makes recommendations for future research on youth, technology, and education. 


\section{Chapter 2 \\ Methodology}

Classrooms are inherently social spaces and the present research is interested in how technology is being used to mediate the social relations and interactions that take place in this setting. To gain an understanding of how technology is impacting the modern university classroom, the data for this research comes from a variety of sources including observation, surveys, and interviews. These combined data sources should help to illustrate the impact of technology on the university classroom, and most importantly, how students respond to the integration of technology into their classes.

This chapter discusses the methodological choices made in the conduct of the research. It includes a justification for the use of a mixed methods research design, discussion of the participants and data sources, a presentation of the ethics considerations, an overview of the three-stage research process and the data analysis strategy, and an assessment of the methods used. As a researcher committed to reflexive research practices, I have endeavoured to be transparent and accountable in the reporting of research procedures and data analysis (see Long and Dart 2001; Bryman et al. 2007).

As presented in the introductory chapter, the current research project is designed around the research question: does the characterization of youth as digital natives apply to young peoples' expectations and experience of education? In pursuing this question, two supplementary questions are considered. First, how do students experience instructor-introduced, and learner- 
introduced technologies in their undergraduate classrooms? And secondly, what do students identify as the role of technology in developing the skills and capacities they hope to advance in their university education? In order to research these questions, a combination of methods is employed. Experience can be difficult to ascertain through empirical research, but the hope is that a mixed methods approach will maximize insight gained in the collection and analysis of data.

\section{Using Mixed Methods}

The decision was made to engage with a mixed methods research design in order to gain as clear a picture as possible of students' experience and expectations of technology in relation to their university education. The mixed methods approach used in the research integrates unobtrusive observation, interviews, and in-depth on-line and hard copy surveys in order to begin to construct answers to the guiding research questions ${ }^{2}$. I would argue that the breadth of these methodologies provides a sufficiently broad range of data to address the guiding research questions. The combination of these methods allows both students and professors to share their experience of technology in their classrooms, while also allowing for the observation of some of these experiences in the field.

A mixed methods approach to data collection has become an acceptable, and in many cases encouraged, form of data collection for sociological research.

\footnotetext{
2 Student focus groups were initially included in the research design, but the number of students who volunteered for participation was not sufficient enough to move forward.
} 
The choice of a mixed methods approach for the current research is in line with Bryman et al. (2007:264), who notes that, "the chief rationale for using this combination of sources of data is that it was felt that a complete picture could not be generated by any one method alone". Because the research aims to target diverse aspects of the experience of technology use in classroom settings, using a variety of methodologies helps to capture different dimensions of this experience.

In choosing a mixed methodology, researchers are confronted with questions about how different methodologies will relate to one another. The current research is pursued from a pragmatic orientation. Onwuegbuzie and Leech (2005) champion a pragmatic approach to research and data collection where both qualitative and quantitative methodologies are used for their strengths. They argue that methodological choices should be driven by the research questions being investigated (Onwuegbuzie and Leech 2005:377). I subscribe to the idea that quantitative and qualitative methods are best utilized as complements to one another and that the mixing of these methods will result in a more in-depth consideration of the issues addressed.

Additionally, the choice of methods for the present project is largely congruent with much of the other research that has been conducted on clickers and laptops. For example, King and Robinson (2009) adopted a mixed methods approach to conduct their study of the use of clickers in Mathematics classes at Loughborough University. Their study combined observations, a one-minute questionnaire on the pros and cons of clickers, informal feedback, and a main 
questionnaire. Their approach to observation is especially similar to that used in the present research insofar as it is intended to observe the ...influence or otherwise use of handsets [clickers] on teaching and learning in the classes where handsets were used" (King and Robinson 2009:192).

The approach to observation in the present research is also similar to that of King and Robinson (2009:192) in that it is open-ended, meaning that the first observation took place without pre-conceived theoretical explanations, and was rather exploratory in nature. The subsequent observations were then shaped by the initial observation in terms of determining which behaviours and events became the central focus. In reference to their own previous research on clickers, King and Robinson briefly drew on surveys and interviews that they had conducted with clicker-using instructors in Mathematics, Geography, and Human Sciences in order to broaden the scope of their data to include the instructor perspective (King and Robinson 2009).

Cutrim Schmid (2008), in the unique position of teacher-researcher, also engaged a mixed methods approach in her clicker research conducted in an English language class for international students at a British university. Her class used a combination of clickers and an Interactive Whiteboard. She video recorded her lessons and wrote field notes after each class to reflect on her perceptions of how the use of clickers impacted her class. Cutrim Schmid (2008:345) also used questionnaires distributed to students at the end of the term. After the term was completed, she also conducted a twelve-student focus group and semi-structured interviews with student volunteers. 
Researchers interested in laptop use in university classrooms have also engaged in mixed methods research designs. In their study of undergraduate student laptop use, McMahon and Pospisil (2005) used a combination of surveys, blogging, and interviews, to hear from the students involved in their research. The students in their study participated in a biweekly blogging exercise about their laptop use and were interviewed as a group at the end of the project.

Similarly, Lindroth and Bergquist's (2010) laptop research also involved a combination of methods including student interviews and field observation in both classes and common areas. Much like the clicker research, this laptop research integrated a variety of methods to collect data on the complexities of student laptop use.

The above examples of mixed methods being employed in clicker and laptop research helped to shape the use of this research design approach in the current project. Combining qualitative and quantitative methodologies allowed previous researchers to collect data on the in-class experience of both students and educators. The use of a mixed methods research design approach is strengthened by these examples of its successful implementation in this area of research.

\section{Participants}

The participants for this project are students from four classes at Carleton University. The classes are all at the undergraduate level and are in the areas of business, science and sociology. The business and science classes are both 
using clickers, while the sociology classes are being investigated for students' use of laptops.

For the clicker portion of the research, there is one business class and one science class, both of which are at the second-year level. The science class has an enrollment of one hundred and twenty-five students and the business class has forty-eight. There are twelve science students and forty-three business students participating in the survey resulting in a total of fifty-five respondents for the clicker survey (though not all respondents answered all questions). Between the two classes there are twenty-four male and twenty-nine female respondents, with two respondents not identifying their gender. Clicker respondents range in age from eighteen to twenty-four, with five respondents not reporting their age. The professors for each of these two classes were also interviewed as part of the clicker portion of this project.

For the laptop portion of this research two large first year sociology classes are participating. This is important because I was particularly interested in hearing from first-year university students, as they are the youngest 'digital natives' currently attending university and therefore are most likely to have grown up with digitally saturated lives. A total of thirty-six first year students responded to the laptop survey - seventeen students from one class and nineteen from the other. Thirteen males and twenty-three females participated in the laptop survey. The age of laptop survey respondents ranged from eighteen to twenty-five. Three respondents are older than the digital native range - they are forty-one, 
fifty, and fifty-two years old. Their responses are excluded from the general data reporting, but are commented on when useful for interpretive purposes.

Four undergraduate classes participated in the research. There were a total of thirty-six males and fifty females, ranging in age from eighteen to twentyfive $^{3}$. Twelve participants are from the science clicker class, forty-three are from the business clicker class, seventeen are from one of the introductory sociology classes and the remaining nineteen students are from the second introductory sociology class.

\section{Data Sources}

The data for this project came from a combination of four data sources. These data sources are unobtrusive observation, on-line and hard-copy surveys, and interviews. Details of each of these data sources are discussed in detail below.

\section{Observation}

Observation of the two clicker classes involved in this research was undertaken primarily because I had no prior experience with clickers and felt it was important to see them 'in action'. Each class was attended periodically over the Fall 2009 semester and field notes were taken. The observations of the two clicker classes included general notes on the class as well as the types of clicker questions that were asked and the interactions that happened around the them.

The observation of the clicker classes provided the basis for both the clicker

\footnotetext{
3 There were two additional females, and one additional male respondent who were older than
} the digital native age range. There were also two respondents who did not identify their gender. 
surveys and the professor interviews that were to follow. Observation only took place in the two clicker classes, however valuable data on students' in-class laptop use was also gathered at this time.

\section{Surveys}

Surveys are used for both the clicker and laptop portions. The surveys are presented to students in an on-line format through the website www.surveymonkey.com, and in the business class as hard copy versions of the on-line survey. There are questions that are common to both the clicker and laptop surveys, and each survey also includes a section of questions specific to the technology being investigated.

The decision to use on-line surveys was made for a few reasons. First, as a researcher who was new to survey use, the Survey Monkey website offered a user-friendly resource that was easy to learn and manage. The use of an on-line survey was possibly also influenced by my own 'digital native-ness' and attraction to and comfort with digital resources. It was also assumed that an on-line survey would appeal to student participants. The collection of qualitative data, in the form of focus groups, was dependent on students first participating in the more quantitative survey portion of the research. Brannen (2005:182) discussed this as a viable way to recruit research participants while also combining methodologies because it allows for preliminary data collection where the survey results can help guide the later direction of the focus groups.

In addition to the personal reasons for using an on-line survey, Fox, Murray and Warm (2003) identify a number of advantages offered by web-based 
surveys. Some of the most appealing advantages were the reduced cost of online surveys, the ease of administering them, and the anonymity they provide (Fox, et al. 2003:167). There is also an undeniable time-saving feature to on-line surveys when compared to using conventional paper based surveys (Fox et al. 2003). This benefit was experienced first hand after the decision was made to administer a paper copy of the clicker survey to the students in the business class. Administering the paper survey greatly improved the response rate for the clicker survey, but resulted in added time at the analysis stage when the results had to be converted to digital to be included with the results of the on-line survey. According to Fox et al. (2003), downsides to on-line surveys include facing potential technical issues, and not being able to provide clarification to respondents who may be unclear about some questions. No technical issues were experienced when using Survey Monkey and the ease of data analysis far outweighed any potential downsides to the use of on-line surveys.

Kay's (2009) study of gender differences in attitudes towards clickers in secondary school is important for encouraging researchers on this issue to pay attention to potential differences in how young women and men experience technology in the classroom. Kay (2009:738) provided a copy of his questionnaire which proved invaluable to the design of the surveys used in the present research. Kay's (2009:732,738) questionnaire included a question on students' comfort level with technology, as well as questions on their attitudes towards clickers, their level of involvement and learning, and an open question for students to comment on the impact of clickers on their learning. 
The surveys designed for both the clicker classes and the use of laptops provide the bulk of data for the research. Both surveys begin with basic demographic questions including age, gender, year of study, and which course the student is in. Following this, students are asked about their ownership of personal technologies such as computers, cell phones and mp3 players, and are asked to rate their general level of comfort with technology. Both surveys use a series of statements and scale-type questions ranging from 'strongly disagree' to 'strongly agree'.

Following these general questions the clicker survey explores a series of clicker specific questions. Students are asked general questions about the use of clickers in their class including whether or not they liked using clickers and what they think about the professor's use of clickers. They are then asked about the impact of clickers on their level of engagement and involvement in the class. Next, students are asked about the impact of clickers on their level of understanding in the class. Additionally, students are asked about the impact of clickers on the classroom learning environment including whether or not clickers help them participate in class and if they find clickers disruptive. And lastly, students are asked about the benefits and challenges of using clickers.

Similar to the clicker survey, the laptop survey includes the same general questions on student characteristics, technology ownership and comfort level, before proceeding with laptop specific questions. There are laptop questions asking about how often students bring their laptops to class and what they do with their laptops while in class. In addition to this, questions are asked about the 
presence of laptops and Internet access in the classroom and can be answered by students regardless of whether or not they bring a laptop to class.

Following the clicker and laptop specific questions, both surveys end with a series of questions about students' expectations of their university educational experience and how technology relates to this. The aim of these questions is to encourage students to think critically about their education and their engagement with technology. As a final question on both surveys, students are asked to provide any additional comments they may have on the use of technology in relation to their undergraduate education. Both surveys can be seen in full in Appendix B.

\section{Interviews}

The aim of the interviews is to engage in an informal, semi-structured conversation with the professors who are using clickers in the two classes that were observed. As the person who made the decision to use clickers, it is important to hear from the professors about their motivations for using clickers and about their in-class experience with them. These two interviews were audio recorded so that they could be transcribed and analyzed at a later date, and both interviews took place in the respective professor's office. One interview lasted around twenty minutes while the other was roughly forty-five minutes, and both were conducted at the end of the term. The interview was intended to be informal but a list of questions was used as a guide. The list of interview questions can be found in Appendix C. 


\section{Ethics}

Because human participants are involved in the research, ethics approval from the Carleton University Research Ethics Committee was required although the research posed no risk to participants. Approval was needed to administer anonymous on-line surveys, and to conduct student focus groups and the interviews with professors. The initial ethics application contained only the clicker portion of the research, meaning that the addition of laptops required a new application. Each of the methodologies used in this research posed separate ethical considerations as can be seen below.

\section{Surveys}

The surveys were designed and disseminated via the website www.surveymonkey.com. Survey Monkey is an American website meaning that participants had to be informed that their survey responses were subject to the Patriot Act (see Letter of Information in Appendix A). The survey was made available to participants through their class's WebCT page which is secure and available only to students registered in the class. For the purposes of analysis, basic demographic information such as age, gender and course number were asked in the survey but there was no way of connecting participants to their survey responses. The Survey Monkey website uses a password protected, secure database to store responses meaning that only the password holder had access to the survey results. 


\section{Interviews}

The individual interviews conducted with two professors using clickers in their classes required signed consent forms (see Letter of Consent in Appendix A). These interviews were audio recorded for analysis purposes. The participants were informed that they could end the interview at any time and that they would not be identified in the final report. Both interview participants agreed that followup questions could take place over e-mail if necessary.

\section{Focus Groups}

Participants were asked to volunteer for the focus groups by sending an email to the address provided at the end of the survey allowing their survey responses to remain anonymous. Participants were informed that their participation in the focus group could not be anonymous within the group but that they could withdraw at any time and that they would not be identified in the final report. Focus group participants were also required to sign a consent form (see Letter of Consent in Appendix A).

\section{Research Process}

The research unfolded in three consecutive stages. These stages overlapped but also contained distinct components. Stage one involved making initial research decisions and applying for ethics clearance. Stage two consistent of the clicker portion of the research, and stage three consisted of the laptop portion as well as the overall data analysis and reporting. 


\section{Stage One}

The first stage of research included deciding on an educational technology to focus on, applying for ethics approval and recruiting participants. Through conversations with the teaching support centre at Carleton University, the decision was made to focus on clickers. The decision to focus on clickers is due to their relative newness and because, very little formal research has been done on their use. Because this project involves human participants, stage one also included applying for ethics approval. The ethics process included designing the survey, outlining the questions I intended to ask for the focus groups and interviews, and drafting letters of information and consent. Ethics clearance was granted on October 9, 2009.

\section{Stage Two}

Stage two made up the bulk of the research as it consisted of the clicker portion of the project which was initially meant to be the sole focus of the research. After receiving ethics clearance, the simultaneous processes of observing the two classes using clickers and finalizing the survey design began. Approximately twelve hours of observation were conducted between the two classes which was broken down into two three hour observation sessions in the business class and four hour and a half observation sessions in the science class.

When the survey was ready to be distributed to participants, the classes were briefly addressed to introduce them to the project and ask for their participation in the survey and focus groups. The link to the survey was then 
provided to the professors to be made available on their course's WebCT page. After making the survey available to participants the responses were monitored every few days to see how many surveys were being completed, and what sort of responses were coming in. The responses were also monitored for focus group volunteers.

Towards the end of the semester, time was scheduled with each of the two professors to sit down for a brief semi-structured interview about their experiences using clickers. By this point in the semester it had also become clear that very few responses to the online survey had been received. As a result of this, the professors were approached about the possibility of administering a paper version of the survey to their students in class. Given that it was late in the semester, only one of the professors was able to accommodate this change. At this time, the decision was made to make the addition of a laptop portion to the project. This addition consisted of designing a new survey and submitting an updated ethics application.

\section{Stage Three}

The final stage of research was a result of the low participation rate experienced in stage two of the project and the realization that laptops could provide an important point of comparison to clickers. The addition of the laptop portion of research received ethics clearance on December 17, 2009. At the beginning of the semester the instructors for two Introductory Sociology courses were contacted to ask permission to survey their students about their use of laptops in relation to their education. Both professors agreed and each class was 
attended to introduce the project to the students and ask for their participation in the surveys and focus groups. Despite the low response rate experienced in stage two, the decision was made to use online surveys and WebCT again. This decision was made because of the ease of designing, administering, and analyzing a new survey, as well as the low cost of using an on-line survey compared to the cost of administering hard copy surveys to two very large classes. In addition to the laptop portion, stage three also included the data analysis process for the entire research project.

\section{Data Analysis Strategy}

The aim of the data analysis is to highlight general themes and interesting anomalies identified across the data sources and is guided by the research questions presented in the introduction to this chapter. The data analysis is treated as an exploration into students' perceptions about their experience of university education and the role of technology in this experience. Where relevant, the results in the present research are considered in light of previous research conducted on both clickers and laptops.

For the clicker portion of the research, the results of the in-class observations, student surveys and professor interviews are analyzed in relation to one another and reported in chapter three. For the laptop portion, the results of the student survey are the primary focus and are combined with observations of student laptop use in the business clicker class, all of which is reported in chapter four. Finally, the results of the survey questions about general technology use, educational expectations, and technology's role in education is the focus of 
chapter five. The data is systematically analyzed to look for differences in responses between the four participating classes, and between the genders. When noteworthy, these differences are presented throughout chapters three, four, and five.

\section{Observations}

In analyzing the field notes from observations of the clicker classes, the types of interactions that took place prior to, during, and directly following the clicker questions are highlighted. Particular attention is paid to the types of discussion that took place in these two classes including student questions pertaining to the lecture, and the occurrence of conversations or comments about the clicker system. The observations of the two clicker classes are also compared and contrasted with each other to look for similarities and differences between the two. The themes identified through the observation of the clicker classes guides the analysis of the clicker surveys and interviews. Observations made concerning the use of personal technologies such as laptops and cell phones in the business class are also incorporated into the discussion of laptops in chapter four.

\section{Surveys}

The surveys resulted in the most substantial data and therefore comprise the bulk of the data analysis. The use of an on-line survey makes analyzing data somewhat easier as it can instantly be converted into tables and graphs, filtered and cross-tabulated. The data from the paper surveys in the business clicker 
class had to be combined with the on-line results of the clicker survey. In order to incorporate the two data sources, the results of the paper surveys were entered into the on-line survey as if they had initially been answered on-line, thus allowing for the merger of the analogue and digital survey results.

In analyzing the survey results, the quantitative results to each question are interpreted as well as paying close attention to any comments made by students when they were given the opportunity to do so. For the clicker survey, the data is analyzed thematically, meaning that in some instances responses are reported in a different order than how the questions were presented on the survey. In both surveys, the overall results are analyzed and interpreted followed by an analysis of the gender and between-class differences in responses. Responses to the laptop survey were also analyzed based on students who reported bringing laptops to class and those who did not.

\section{Interviews}

To analyze the two interviews with clicker-using professors, their insights are compared and contrasted with the survey responses and classroom observations. Particular attention is paid to their reasons for using clickers in their classes and the challenges that they faced in using clickers. The first-hand accounts provided by these professors is treated as an important contribution to understanding the student experience of technology in university classrooms. 


\section{Reflexivity}

By many accounts, I exhibit digital native characteristics. I was born in 1986 - right in the middle of the net generation according to Tapscott (1998, 2009). I attended computer classes in elementary school, had to hand in word processed assignments in junior high school, and had a personal e-mail address before my parents. This puts me in an interesting position as a researcher because most of the existing research on digital natives has been conducted by non-natives, or what Prensky (2001a) refers to as 'digital immigrants'. So, while the focus of the research is on the use of technology in undergraduate classrooms, and the research participants are undergraduate students, I am, in many ways, a subject of my own research. My positioning as a young person conducting research on the experiences of other young people is one of the unique contributions of this project.

My own experiences as a digital native aged student have influenced my data interpretations in terms of the responses that I am surprised by (or not), or find most interesting. My many similarities to the participants has also made me more acutely aware of the diversity within the generation of youth involved in the research, which has influenced my critical reading of the digital native theory interrogated by the research. In a discussion of the importance of reflexivity at the stages of data analysis and interpretation, Mauthner and Doucet (2003) suggest that while it is possible to gain aspects of research participants' experiences it is impossible to know them fully. This is true even despite my similarity to the students participating in the research. 


\section{Methodological Reflection and Assessment}

The entire research process involved making important decisions that directly impacted the outcome of the research. The decisions made around recruitment, utilizing on-line surveys and administering focus groups were especially influential. These choices are reflected on below.

\section{Recruitment}

The recruitment process proved challenging to the research proceedings because there were a limited number of classes using clickers at the time the research was conducted. Recruiting student participants also proved to be challenging, which was likely the result of the amount of time between initially hearing about the research in class, and then being provided with the link to the on-line survey. Additionally by using on-line surveys, students were being asked to use their own time to complete the survey, instead of using class time to complete a paper survey. It is also unclear how the link was presented to students on their course's WebCT pages. Gaining access to these pages was not possible and it was therefore asked that the professors make the link available. Not having control over this aspect of recruitment may have been a contributing factor to the low survey response rate.

Recruiting focus group participants through the on-line survey did not work. The effort was made to ensure students knew about the focus groups when their classes were addressed about the research, but it was left up to participants to volunteer by sending an e-mail after completing the survey in order to maintain the anonymity of survey respondents. However, given the low survey response 
rate, and the fact that it was late in the semester, it is probably not surprising that students did not volunteer to participate in focus groups.

\section{On-line Versus Paper Surveys}

The use of on-line surveys did not result in the response rate that was anticipated. Research began with the assumption that using on-line surveys would appeal to student participants. Given that the research focus is on the characterization of today's students as 'digital natives' who are supposed to desire technology in their education, it was thought that making the on-line survey available to students through WebCT would be a successful way to engage participants. I was also interested in using an on-line survey because of the ease of data collection and analysis provided.

In the clicker portion of the research the assumptions about on-line surveys were proven wrong. After a number of weeks of the survey being available to approximately two hundred students, there were only eighteen survey responses. The low response rate resulted in having to make paper surveys available to the students in the business clicker class. Resorting to the use of paper surveys meant that the results then had to be inputted by hand to combine them with the on-line survey results. The low response rate did however lead to the inclusion of the laptop portion of the research which helped to enhance the project overall. Ultimately, despite the recruitment challenges, the website was a great resource, and the use of surveys was necessary to hear from as many students as possible. 


\section{Focus Groups}

The research was envisioned to be a somewhat collaborative project within which the focus group participants would help to steer the direction of the research. This unfortunately did not work out. Hearing from students directly was not possible within the scope of the research but it is important for research in the area of education and technology. It is recommended that future research on education and technology should employ focus groups as a way of further involving students in the discussion.

\section{Summary}

This chapter provides a detailed discussion of the various methodological considerations involved in the research. The aim of this chapter was to present the research design, ethical considerations, and data sources, collection and analysis. Effort has been made to critically examine the various stages of the research process by highlighting both the strengths and weaknesses of the methodological choices.

The participants involved in the research are draw from four undergraduate classes in the areas of business, science and sociology. In total, ninety-one students responded to the surveys used, and two professors were interviewed about their use of clickers. In addition to surveys and interviews, unobtrusive observation was conducted in the two clicker classes.

In designing the research the decision was made to use a mixed methods approach to data collection in order to gain as clear an understanding as possible of the role of technology in undergraduate classrooms. The methods used 
included unobtrusive observation, on-line and hard copy surveys, and interviews. Together these methods allowed for the combining of qualitative and quantitative data, and for responses to be gathered from both students and professors. The following chapter is a discussion of the clicker portion of the research. 


\section{Chapter 3 \\ Digitally Mediated Interaction}

This chapter presents the results of the clicker portion of the research. The results combine the observational, survey, and interview data collected from two clicker-enabled classes. Most of the respondents - forty-three of fifty-five came from the business class meaning the results are most representative of the students in this class ${ }^{4}$. The data is presented thematically and each section begins with a discussion of the relevant observation findings in order to anchor the analysis with what was witnessed in the classrooms. The results of the surveys and interviews are incorporated into the discussion of the themes that were identified in the observation field notes. Where relevant, a discussion of significant anomalous findings is included.

There are two classes involved in the clicker portion of the research. One is a small second-year business class with forty-eight students enrolled, and the other is a mid-sized second-year science class with one hundred and twenty-five students enrolled. Both of the clicker classes participating in the research are using clickers anonymously, meaning that the professors have no way of knowing which students are using clickers or how individual students are responding. The business class has absolutely no grade connected to the use of clickers, and according to the syllabus for the science class, students are given $1 \%$ of their grade for picking up a clicker. In other words, clickers are by no means a requirement for either class (because there are no consequences, positive or

\footnotetext{
4 Importantly, the science respondents represent only $10 \%$ of their class, and their responses, though noteworthy, may not be representative of the science class as a whole.
} 
negative, to using or not using clickers, there is not full student buy-in in either of the classes).

The subject matter of each of these two classes - business and science - is important to note because of the type of knowledge that is used and produced in each class. In comparison to social sciences or humanities classes, the two classes observed deal primarily with facts as opposed to interpretation. It is likely that the subject matter of the two classes had an impact on the way clickers were used.

The findings in this chapter are also related to previous research on clickers, as well as Prensky's and Tapscott's discussions of digital natives and the net generation. Clickers represent the introduction of a technology into the classroom by the instructor who is then largely in control of their use. Because clickers are not an every-day, personal technology, they provide an interesting example of educational technology and are therefore a useful entrance into a discussion with students about their views on technology in their classrooms. The findings in this chapter suggest that there is support for the digital native characterization of modern students, in terms of their ability to learn new technologies, and their desire to have fun and collaborate while learning. The findings also seem to support the further integration of digital technologies into university classrooms.

The number of clicker questions varied from class to class and it was often the case that questions would need to be skipped over because there was not enough time for them. The first time the business class was observed they were 
reviewing for their midterm and the lecture incorporated fourteen clicker questions. In contrast to this, the second time this class was observed there were only three clicker questions, all of which took place in the first half of the lecture because there was a group activity scheduled for the second half. The science class seemed to be more consistent with its use of clickers, and incorporated three to five clicker questions throughout each of the four lectures observed.

Three themes emerged strongly from the multiple data sources analyzed. One of the most pronounced findings is how the presence of clickers and clicker questions changes the lecture in comparison to more standard lectures where clickers are not present. Furthermore, the issue of student involvement and participation in class is also present across all data sources. Lastly, the presence of technological discourse focused on the clicker system and its challenges is evident across the data sources.

\section{The Presence of Clickers and Clicker Questions}

Utilizing clickers means utilizing clicker questions which were found through observation to be much more important than the actual clicker devices in terms of the social happenings in the classes observed. This was because clicker questions and results are presented to all of the students in the class regardless of whether or not they have a clicker. And, it is the clicker questions that 'test' students and lead to further learning and discussion, not the clickers themselves. The clickers allow for instant feedback to the clicker questions and the display of how students respond, but it seems that from a pedagogical standpoint it is the 
clicker questions that are important. The system of regular, periodic questioning is a distinguishing feature of a clicker-enabled classroom.

In other words, the introduction of a new interactive technology into the classroom results in substantive changes in the learning environment. The interactive aspect of clickers is an important distinction to make, because it means that clickers are qualitatively different from more standard classroom technologies such as PowerPoint. The clicker devices interact with the clicker receiver which then relays the results to the class via the PowerPoint slide, leading to further interaction between students and the professor. As I will argue, these technological interactions are both facilitating and hindering social interactions within the classroom.

In the first observation of the science class the following field note was recorded: "Clicker questions are easy to identify even though they look like other text based slides. Something changes as soon as these slides come up. A pause?". Subsequent class observations revealed that this was a general feature of clickers in the classroom. This feeling of change happened in both classes any time a clicker question appeared on screen. In both classes the professors used very simple PowerPoint slides that usually consisted of a white background with black text, and this format was the same for the clicker question slides. It appeared as though it was a bit of a surprise when a clicker question slide came up on the screen. Not in the sense that they were disruptive or completely unexpected, but that they simply broke the flow of the lecture. When the slides appeared, the professors would usually then announce that it was time to use the 
clickers. At the appearance of a clicker question both the professor and the students would re-focus their attention to read, respond to, and in most cases, discuss the current clicker question. Below are two examples of clicker question slides:

Sam wants to buy a new laptop. He has been reading Consumer Reports and asking friends for recommendations. What stage of the decision making process is he in?

1.Problem Recognition

2. Information Search

3. Info Recognition

4. Decision-making
5. Evaluation of alternatives

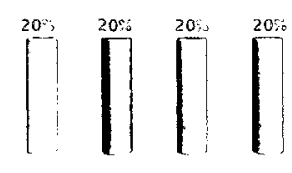

III. 3.1 Sample business class clicker question slide
Older phloem and epidermal cells are casualties of secondary growth. Which other cells in this image succumbed to a similar fate?

1. Ray parenchyma.

2. Pith parenchyma.

3. Cortex parenchyma.
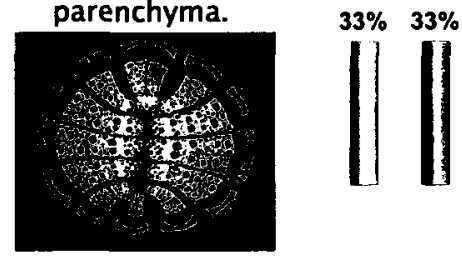

These slides represent what appeared throughout the observations to be the standard clicker question slide format. The question is at the top of the slide followed by the answer options listed on the bottom left half of the slide. After students use their clickers to respond, the distribution of responses is displayed in a bar graph on the bottom right half of the slide. As can be seen in the sample science slide, images can also be included as part of the question.

The spontaneous quizzing and instantaneous display of results is what makes clickers so unique and what distinguishes clicker-enabled classes from more standard lectures. Through the use of technology, students are able to instantly see how they are doing in relation to their peers and the professor is 
able to see how the class is doing as a whole. This form of monitoring student progress is not generally feasible in a standard lecture setting.

A number of similarities were observed in regards to the types of discussion that took place during and directly following the clicker questions in both classes. It was often the case that the professors would narrate what was happening as the clicker question was being answered. The professors would also often check with the students to see if they required more time to vote, and on occasion would re-word the question as students were in the process of answering it. The use of clickers and clicker questions resulted in a new narrative and social interaction taking place within the clicker-enabled classroom. Seeing the instant results of how well the class was grasping a concept or topic allowed for the professors to know if they needed to provide more detail or further explanation that may not have been garnered without the feedback provided by the use of clickers.

This is a pedagogical benefit of clickers discussed by many of the others who have done research on clickers. For example, Mayer et al. (2009) argue that students in large lecture hall classes are less likely to feel involved in the class and therefore less likely to engage with the class material. They suggest that students in these types of classes will do better when they experience at least some level of student-instructor interaction and that the use of clickers can help to facilitate this learning experience (Mayer et al. 2009:51). The science class took place in a large lecture hall but, based on observation, seemed to have more voluntary student participation than the business class which took place in 
a much smaller classroom, suggesting that there may be factors other than the size of the classroom that impact the level of student participation. Additionally, Jones et al. (2009:3) note that student-faculty interaction is an important pedagogical goal and that, "clicker use promotes this type of interaction through discussion that follows the correct answer to a question being revealed". Through observation, it was found that the professors would discuss not only the correct answer, but also why the other answer options were incorrect. This was especially noticeable when large numbers of students selected an incorrect answer. Pedagogically, both the business and science class appeared to reap some benefit from using clickers in terms of the type of engagement that was made possible though the use of clickers.

The science professor was particularly good at discussing both the correct and incorrect answers following clicker questions and linking the questions to information that the students had previously learned. This professor would often make predictions on how well they thought the students would do on the present clicker question, and then spend more time discussing the clicker questions that students did not do well on. It was often the case in both classes that when the majority of the students responded correctly the professor would move on quickly with the lecture. This finding is in line with Jones et al.'s (2009) argument that clickers can be used by professors to help gauge how much time should be spent on a topic based on how well students do on the clicker questions. When the responses to the clicker questions demonstrate that students are understanding the material, the professor knows they can proceed with new material. 
Clicker questions generally led to clarification, whether it was the professor clarifying what they meant by the present clicker question or why the chosen answers were correct or incorrect, or students asking for further clarification after seeing the results of the question. This system of periodic questioning led to forms of discussion and levels of explanation that seemed easier to achieve in a clicker-enabled classroom than it would be in a more standard lecture setting where planned questioning is not present.

The first lecture observed for the business class was a review in preparation for the midterm and used fourteen clicker questions throughout the lecture to demonstrate the types of questions that students might encounter on their upcoming midterm. This seemed to be a valuable use for clickers as students were able to get firsthand experience practicing questions similar to those that would be found on the midterm. In conjunction with the clicker questions the professor spent considerable time sharing strategies for how to do well on the midterm. In both classes, their formal evaluations consisted of multiple choice midterms and final exams, suggesting that regularly experiencing multiple choice questions throughout the term via the use of clickers was quite possibly beneficial.

\section{Surveys}

Survey participants were asked to rate four statements pertaining to their level of understanding in their clicker-enabled class. When asked to rate the statement "seeing the results of clicker questions helps me know how well I am understanding the lecture material" (see Q1: Results, Chart 3.1), twenty-nine 
respondents agreed and fifteen strongly agreed. This means that a full $80 \%$ of respondents found that clickers aided their understanding of class material by helping them to judge how well they were comprehending the material being presented to them. When looked at by gender, just over half of both male and female respondents agreed with this statement while females were more likely to strongly agree, and males were more likely to be neutral. In the science class, $58 \%$ of respondents strongly agreed with this statement while the remaining $42 \%$

Chart 3.1: Understanding $(n=55)$

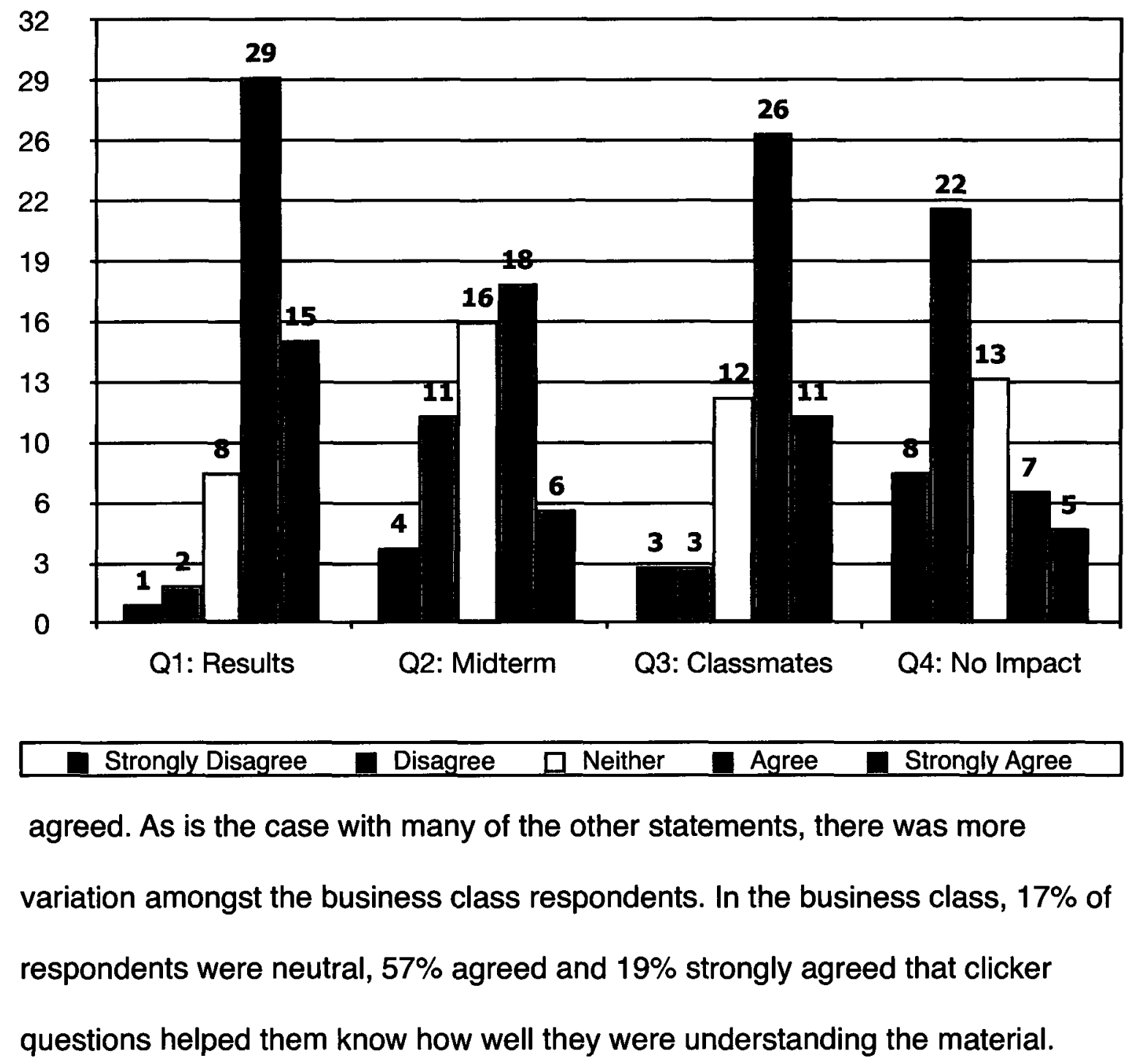


Despite this variation though, they majority of business respondents did report at least some level of agreement with this statement. Clicker questions can act like a test or review of lecture material and students generally seem to like this feature of using clickers.

In addition to seeing their own understanding, twenty-six respondents agreed and eleven strongly agreed with the statement "I like seeing how well I am understanding the lecture in comparison to my classmates" (see Q3: Classmates, Chart 3.1). In response to this statement, $21 \%$ of both males and females were neutral, while females were slightly more likely to both agree $(52 \%$ compared to $46 \%$ of males), and strongly agree ( $24 \%$ compared to $17 \%$ of males). The science respondents showed no disagreement with this statement, while the respondents in the business class were varied in their responses. The level of agreement with this statement is supported by Kay and LeSage's (2009) review of research on clickers which also found that students like to see how well their peers are doing in terms of understanding lecture material.

When presented with the negatively worded, "the clicker questions have had no impact on my level of understanding in this class" (see Q4: No Impact, Chart 3.1) the results still communicated that respondents found clicker questions helped with their level of understanding as demonstrated by the twenty-two respondents who disagreed and eight who strongly disagreed with this statement. Between the genders, there was essentially no difference in the numbers who disagreed and strongly disagreed with this statement. In the two classes, roughly the same percentage of respondents disagreed with this 
statement. This further suggests that using clickers influences respondents' level of understanding.

The clicker survey was presented to students late in the semester so they were presented with the statement "the use of clicker questions helped me know what to study for the midterm" (see Q2: Midterm, Chart 3.1). Respondents were surprisingly neutral on this question. Thirty-eight percent of females were neutral and an additional $31 \%$ agreed with this statement compared to $17 \%$ of males who were neutral and $38 \%$ who agreed. No females strongly disagreed with this statement but $17 \%$ of males did. One quarter of the science respondents strongly agreed with this statement while an additional $50 \%$ were neutral. In comparison, $7 \%$ of the business respondents strongly agreed, $41 \%$ agreed, $21 \%$ were neutral and $24 \%$ disagreed. The responses from the business class are particularly interesting because, as mentioned above, clickers were used for a midterm review class. In combining the two classes, sixteen respondents said they neither agreed nor disagreed with this statement. Respondents who either disagreed or strongly disagreed represent $27 \%$ of the respondents who answered this question, compared to the $44 \%$ of respondents who either agreed or strongly agreed. This suggests that, in general, respondents did see some correlation between using clicker questions and preparing for their midterm.

Further related to understanding, students were presented with statements throughout the clicker portion of the survey on whether or not clickers help them pay attention to the lecture. Students were presented with the statement, "there is too much time spent on clicker questions and not enough time spent on the were 
actual lecture" (see Q1: Too Much, Chart 3.2). In response to this statement, thirteen respondents strongly disagreed and an additional twenty-four disagreed, while only three agreed and six strongly agreed. This suggests that in general, respondents did not have a problem with the amount of time spent on clicker questions in comparison to the rest of the lecture.

The numbers of males and females who disagreed with this statement were similar ( $46 \%$ and $41 \%$ respectively) but there was a greater difference in the numbers who strongly disagreed ( $13 \%$ of males compared to $35 \%$ of females).

Chart 3.2: Disruption $(n=55)$

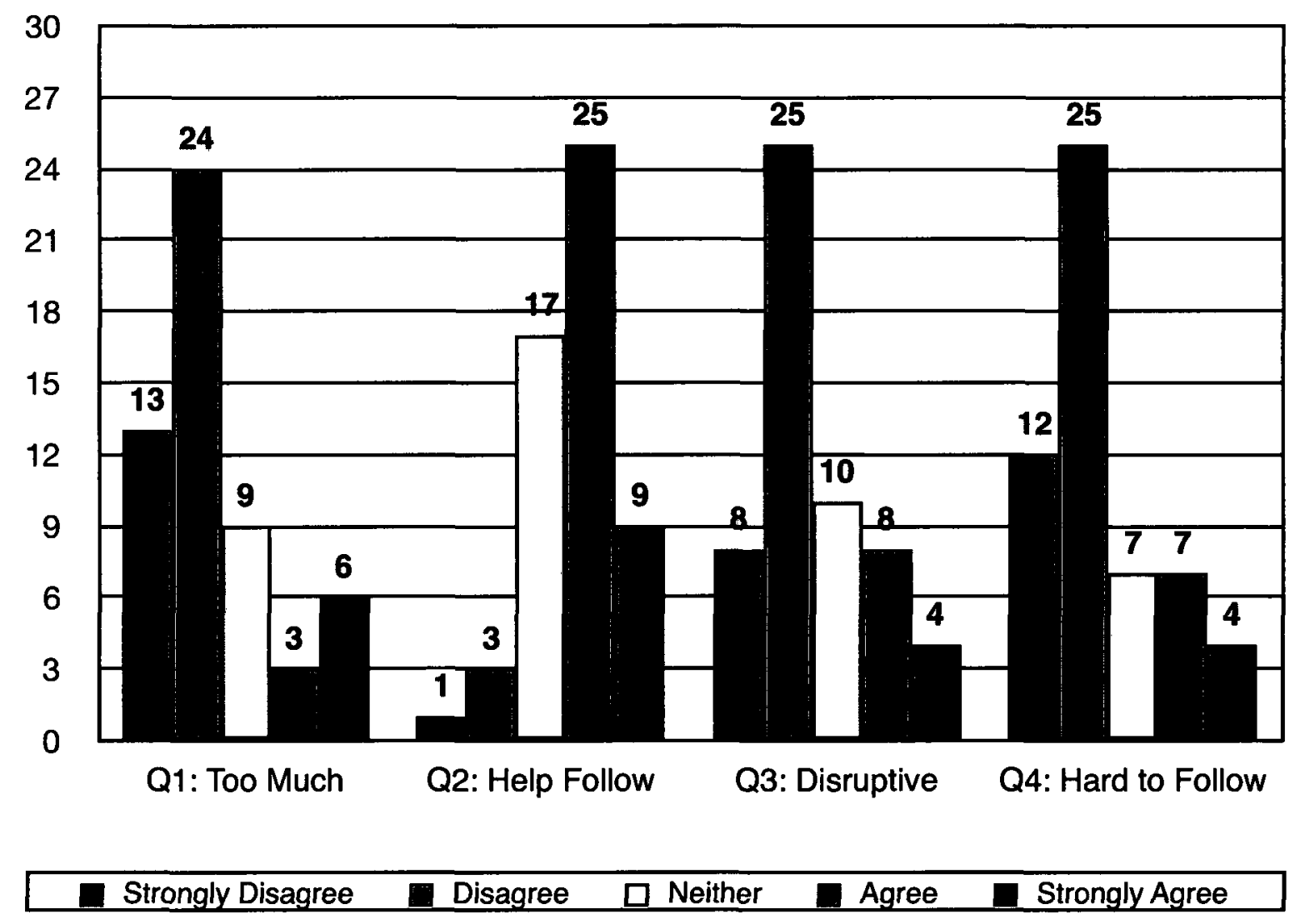

In the science class, $75 \%$ of respondents strongly disagreed with this statement and the remaining $25 \%$ disagreed suggesting that the respondents in this class 
generally pleased with the amount of class time given to the use of clickers. In comparison, the business class respondents were more varied. Half disagreed and a further $10 \%$ strongly disagreed, but $14 \%$ strongly agreed, and $7 \%$ agreed that there was too much time given to clicker questions.

Students were also presented with the conflicting statements, "using the clickers to answer questions during lecture helps me follow the lecture" (see Q2: Helps Follow, Chart 3.2), and "the clicker questions make it hard to follow the lecture" (see Q4: Hard to Follow, Chart 3.2). As can be seen in Chart 3.2, the responses to these two statements were generally consistent. The same number of respondents - twenty-five - agreed that clickers were helpful and disagreed that they make it hard to follow along. More respondents strongly disagreed that clickers made it hard to follow the lecture, further supporting the responses to the first statement that clickers help.

When looked at by gender, $17 \%$ of both male and female respondents strongly agreed that clicker questions helped them follow the lecture. More females agreed with this statement ( $55 \%$ compared to $38 \%$ of males), and more males were neutral ( $38 \%$ compared to $21 \%$ ). In response to the second statement, males and females consistently reported disagreeing ( $42 \%$ of males and $48 \%$ of females), and strongly disagreeing ( $25 \%$ of males and $21 \%$ of females) that clicker questions make it hard to follow along. More respondents in the science class strongly agreed that clicker questions help them follow the lecture ( $42 \%$ compared to $10 \%$ in the business class). However, an additional $50 \%$ of the business respondents and $33 \%$ of the science class agreed. Thirty- 
four percent of the business respondents were neutral as to whether or not clicker questions help them follow the lecture compared to only $8 \%$ of the science respondents. In response to the second statement, $58 \%$ of the science respondents strongly disagreed, and a further $33 \%$ disagreed. In the business class, $50 \%$ of respondents disagreed, and $12 \%$ strongly disagreed, but there was also $17 \%$ who agreed and $8 \%$ that strongly agreed that the clicker questions made it hard to follow along. In terms of following along with the lecture, the science respondents found clickers to be very helpful, while the business respondents also found them helpful, but to a slightly lesser degree.

The last attention related statement was, "the clicker questions are disruptive to the lecture" (see Q3: Disruptive, Chart 3.2), and respondents were generally in disagreement with this statement. This demonstrates that respondents do not find clicker questions disruptive even though they happen at varying times and frequencies throughout the lecture. Thirty-three respondents either disagreed, or strongly disagreed with this statement compared to the twelve respondents who agreed and strongly agreed. Between the genders, more females than males disagreed that clicker questions are disruptive to the lecture (52\% compared to $42 \%$ of males). In the science class, half of the respondents strongly disagreed and the remaining half disagreed that clicker questions are disruptive. In comparison, the business class was split with $29 \%$ finding clickers disruptive and $45 \%$ not finding them disruptive, thus showing some support for clickers not disrupting the lecture. The general responses to 
this statement in particular are compared to some of the laptop results in the following chapter.

\section{Students' In-class Participation and Involvement}

Clickers are designed to help engage students in the lecture but a number of cases were observed where the clicker questions lead to participation beyond simply clicking in an answer. In both classes observed, not all students seemed to use clickers - either they never picked one up, or they simply did not have their clicker with them on that given day. What is interesting though is that not having a clicker does not exclude students from participating. When presented with a clicker question, many students were likely to discuss the answer with their near-by peers whether they were answering with a clicker or not. Some students would also offer a verbal response to the question when they were not using a clicker. In this way, I would argue that it was the clicker questions and not the clicker device per se that lead to student engagement and participation.

Researchers who have done previous work with clickers seem divided when it comes to allowing students to discuss the clicker questions prior to answering. Jones et al. (2009), suggest that allowing students to talk about the answers could be considered a form of cheating. In contrast to this, Cutrim Schmid (2008) found that students want to be able to discuss answers, and suggests that they should be allowed to do so. Given that the students in the two classes participating in the research were not being graded on the clicker questions, discussing the clicker questions can hardly be seen as cheating. If 
anything, discussing the clicker questions may have lead to better levels of understanding than simply guessing and clicking.

The student conversations observed suggest that clickers and clicker questions can help to facilitate student to student discussion that might not otherwise take place, especially in a more standard lecture setting where the professor talks to the students for the duration of the class. Clicker questions allow for punctuation in the lectures and an opportunity for students to test their understanding of the lecture materials - a form of participation that is not commonly present in a standard lecture. According to both Prensky (2001a) and Tapscott (2009), collaboration should be encouraged in educational settings because digital native students like to be able to collaborate in everything they do. The desire to collaborate comes from their being accustomed to having connection to each other in their daily lives through various social media and mobile technologies (Prensky 2001a; Tapscott 2009). It is possible that students were demonstrating a desire to collaborate when they would discuss the answers as they were presented with clicker questions. And, if collaboration is something that students want from their education then perhaps discussing clicker questions should be further encouraged as suggested by Mayer et al. (2009).

While the students in the business class tended not to participate too much beyond the clicker questions during the lectures that were observed, there seemed to be a more open feel to the science class. Students in the science class were more likely to pose questions throughout the lecture and to ask for further clarification following clicker questions. In addition to the lecture, the 
science class had a mandatory lab, while the business class would incorporate group work (at least on one of the days observed), and involved group projects and presentations. Both classes then, incorporated and encouraged student participation beyond the use of clickers.

\section{Surveys}

On the clicker survey, students were presented with a series of six statements about their levels of participation and involvement in their clickerenabled class. Students were asked to rate their level of agreement with each of the statements on a five-point scale ranging from 'strongly disagree' to 'strongly agree'. The responses to these statements can be seen in Chart 3.3 and Chart

\section{4 .}

When presented with the statement "using clickers has helped me engage in class" (see Q1: Engagement, Chart 3.3), twenty-nine of the fifty-five participants said they agreed with this statement while ten said they strongly agreed. In contrast to this, there were only eight respondents who either disagreed, or strongly disagreed with the statement. This means that almost three quarters $(71 \%)$ of the survey respondents find that clickers benefit their engagement in the class. An additional eight respondents neither agreed nor disagreed with the statement. Using clickers then, appears to be a productive way to help students engage with lecture material. In terms of gender, female respondents are more in agreement with this statement, while the three respondents who strongly disagreed were all males. Between the two classes, respondents from the science class were more likely to agree with this statement. 
The science class took place in a lecture hall as opposed to the smaller room that the business class was conducted in. Perhaps then, as suggested by Mayer et al. (2009), there may be some correlation between room size and clicker use insofar as clickers can be used to encourage engagement in large classrooms.

Chart 3.3: Participation

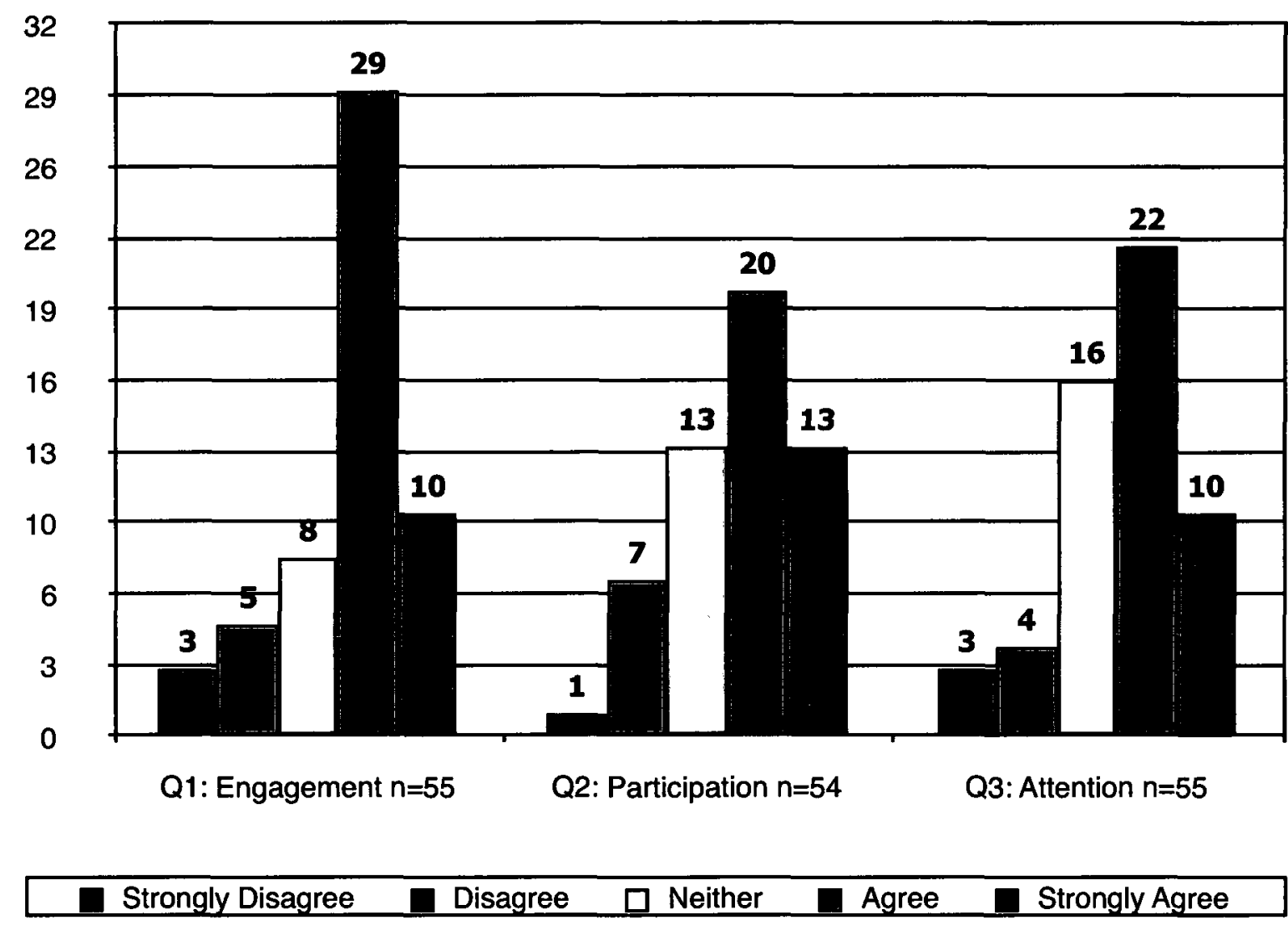

Participants were next asked to rate their level of agreement with the statement, "knowing that there will be clicker questions throughout the lecture causes me to pay closer attention to the lecture" (see Q3: Attention, Chart 3.3). In response to this statement twenty-two of the fifty-five respondents said they agreed and ten strongly agreed, while sixteen neither agreed nor disagreed, further suggesting that students find clickers and clicker questions aid their 
engagement with the lecture material. Female respondents were more likely to be in agreement with this statement while male respondents were more likely to be neutral. Respondents from the science class were slightly more likely than the business respondents to rate this statement with a level of agreement, while a full $31 \%$ of the business respondents were neutral in response to this statement. The $31 \%$ of the business respondents who were neutral on this statement demonstrates that while, in general, respondents agree that clickers help them pay attention to the lecture, there is also a notable number of students who are less certain about this.

The third participation related statement read "my level of participation in my class with clickers is higher than my level of participation in classes without clickers" (see Q2: Participation, Chart 3.3). Of the fifty-four participants who answered this question, twenty agreed while thirteen strongly agreed and another thirteen neither agreed nor disagreed. This means that $61 \%$ of the respondents agreed to varying levels that they participated more in their clicker-enabled class than they did in their clicker-less classes. Approximately one quarter of both the male and female respondents strongly agreed with this statement, but female respondents were much more likely to agree ( $45 \%$ compared to $26 \%$ of males).

One half of the science respondents strongly agreed with this statement and an additional quarter agreed, meaning that $75 \%$ of the science respondents demonstrated a level of agreement with this statement. In comparison, only $17 \%$ of the business class strongly agreed, but $42 \%$ agreed. So, while there is variation between the genders and the classes, in general, respondents agreed 
that their level of participation was higher in their clicker-enabled class. It cannot be assumed however, that the clickers were the sole reason for these higher levels of participation.

Interestingly, when asked to rate the statement "using clickers has not changed my level of involvement in class" (see Q1: Involvement, Chart 3.4), fourteen participants agreed and four strongly agreed with this statement. Meanwhile, twenty-one disagreed and five strongly disagreed, meaning that since this question was negatively worded, they agreed that clickers had changed their level of involvement in their clicker-enabled class. The responses to this statement again suggest that students find clickers to be a beneficial aid to engaging and participating in class. Male respondents were very divided in response to this statement with $38 \%$ agreeing with it and $46 \%$ disagreeing with it. In comparison, female respondents were less likely to agree, with $28 \%$ neither agreeing or disagreeing and an additional $31 \%$ disagreeing. Respondents from the science class were more likely to demonstrate a level of disagreement with this statement suggesting that clickers had more of an impact on their level of involvement than the students in the business class. This could again lend credence to Mayer et al.'s (2009) finding that clickers can be beneficial in large lecture classes.

Under the heading 'Learning Environment' students were asked two further questions about their participation in their clicker-enabled class. First, participants were asked to rate the statement "I feel comfortable participating in this class because of the use of clickers" (see Q2: Comfort, Chart 3.4). In 
response to this question, twenty-one respondents said they neither agreed nor disagreed with this statement while eighteen agreed and seven strongly agreed. Only one respondent strongly disagreed with this statement. Thirty-eight percent of both males and females were neutral in response to this statement and similar numbers of both males and females agreed. Females though, were more likely to strongly agree with this statement.

Chart 3.4: Involvement

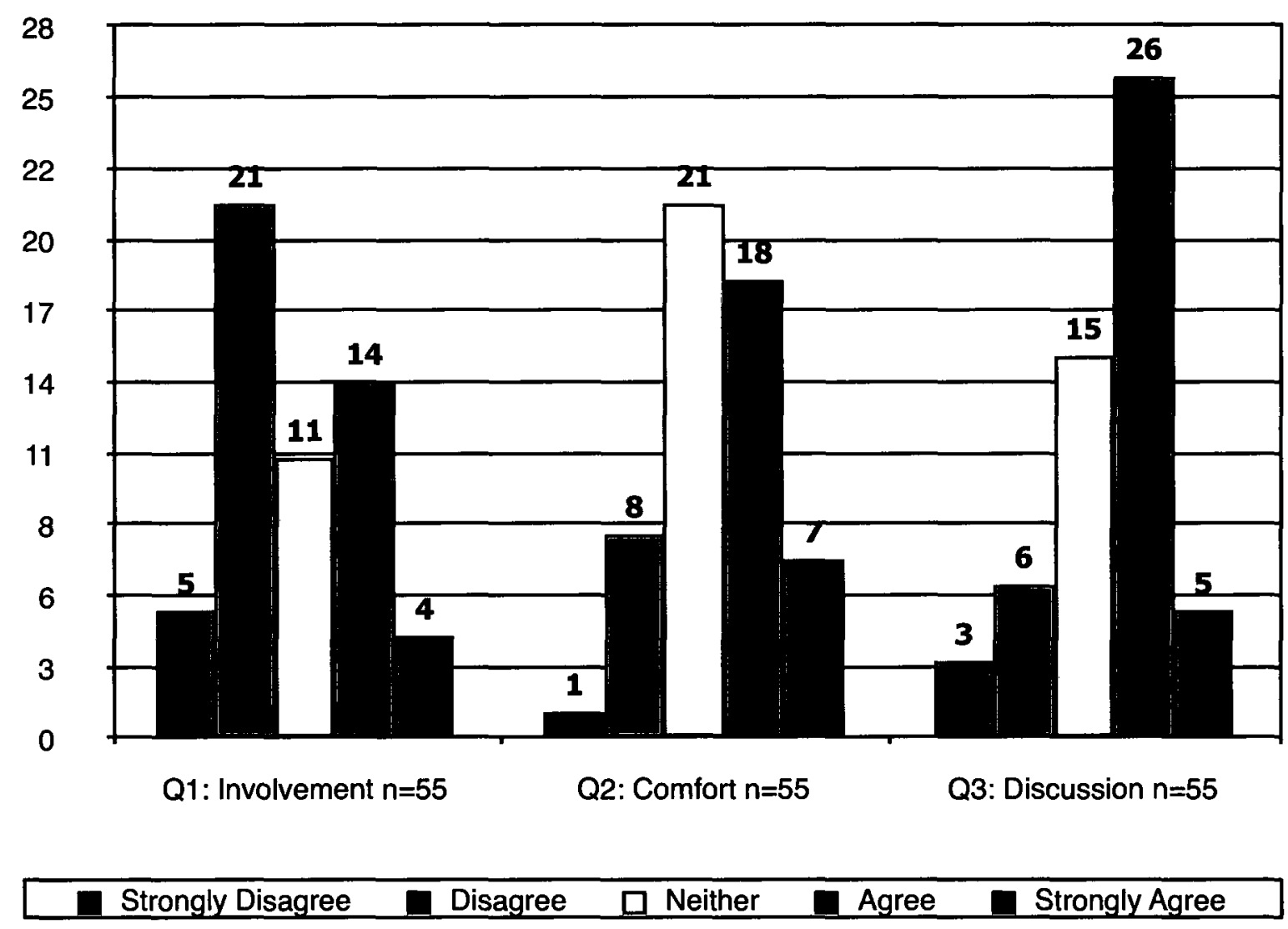

All those who responded to this statement with a level of disagreement were from the business class, while respondents from the science class were most likely to strongly agree. The responses to this statement demonstrate some uncertainty about the impact of clickers on students' level of comfort with 
participating in class. It is possible that students who are normally uncomfortable with participating in class remain uncomfortable, even when they can use clickers. The same can also be said for those students who are comfortable with participating in their non-clicker classes. It is also possible that students in the business class were already comfortable with participating in their class, while students in the science class were not.

Lastly, students rated the statement "the clicker questions help to generate class discussion" (see Q3: Discussion, Chart 3.4). Twenty-six respondents agreed and five strongly agreed with this statement while fifteen were neutral and six disagreed. The majority ( $85 \%$ ) of male respondents said they either agreed or strongly agreed with this statement compared to $45 \%$ of female respondents. Again, all of the respondents who either disagreed or strongly disagreed with this statement were from the business class. The responses to these two questions suggest that there may be a relationship between clicker use and student participation, especially in terms of generating class discussion.

\section{Interviews}

The professors for each of the two clicker classes participated in interviews near the end of the semester, and both were using clickers for the first time. When asked in their interview why they wanted to use clickers in their class, the science professor said it was because of the claim that they would make the class more interactive. After using clickers they found that one of the only benefits of the clickers was that they helped to "keep the students awake". They also found that using clickers helped them to slow down while lecturing. Slowing 
down the lecture was one of the many pedagogical benefits of clickers that were identified by others who have researched their use (see Kay and LeSage 2009; King and Robinson 2009; Hoffman and Goodwin 2006). The science professor found that the group of students in their clicker class were the "best crop of students I've had", but they were hesitant to attribute the students' success to clickers. This professor was quick to respond to the question of whether or not they had heard anything from their students about clickers, noting "It's unanimous! They love them!". Perhaps then, enjoying the interactive technology that helps them 'stay awake' was a factor in their success.

The business professor addressed the question of student participation more directly when asked if they had heard from students about their use of clickers. This professor said that $5 \%$ of their class grade was for participation, but that they were very clear that using clickers was not part of this grade. To get participation points students had to speak in class or contribute to the class discussion boards on WebCT. The professor said that they had one student at the end of the semester who was angry that they were not receiving participation grades for having used their clicker. This happened despite the fact that the professor had repeatedly told the class that they would not. What this dispute interestingly demonstrates, is that this student did associate the use of clickers with participating in class, even when they are used anonymously and are not associated with their grades. It is possible that because, according to digital native theorists, young people today spend so much time participating in various anonymous online activities such as socializing and gaming, they feel that 
anonymous participation should count for something in the classroom. Based on the responses to the six preceding questions, there is general support from the students who responded to the clicker survey that clickers aid their level of inclass participation and involvement.

\section{Technological Discourse}

Another discernible difference between the clicker-enabled classes observed and a more standard lecture was the presence of technological discourse. This discourse was usually in reference to a problem (either real or anticipated) with the clicker system, and was generally initiated by the professor. While this can sometimes be experienced in a standard lecture when PowerPoint fails to work, it seemed to be more prevalent in the clicker-enabled classes. Technical "hiccups" were one of the main problems with the clicker system that were identified by Hoffman and Goodwin (2006). Due to the ubiquity of the use of PowerPoint in university lectures at the undergraduate level, classrooms are generally set up to accommodate PowerPoint and its use is generally reliable.

Clickers on the other hand are far less common than PowerPoint and are therefore less accommodated. No real problems with clickers were witnessed during the observation, but there were numerous references made to past problems and a few clicker-related delays. Reference to clicker problems were present in both the business and science classes and were emphasized by the professors in their respective interviews.

On the first visit to observe the business class there was a delay in starting because the professor seemed to be having some difficulty setting up the clicker 
receiver. As was often the case when something went wrong with the clicker system, the professor made a joke about having difficulty getting the clicker system to work, and made reference to past trouble with the system. The professor then told the class that they had installed the receiver differently on that particular day and hoped that this change would make a difference. Talk of clickers and receivers are obviously not present in standard lectures, but these terms seemed to be part of the clicker-enabled class lexicon, and this discussion did not seem to be out of the ordinary.

In addition to the delay in setting up the clicker system, there was concern during the first clicker question of the class that the system was not going to work. The clicker question came up on the slide and the students clicked in their answers but there was a delay in the results being displayed. In this case some students made suggestions to the professor when it looked like the clicker system was not going to work. This could be seen as an example of these students' digital native-ness because of their apparent comfort level with the technology. The students were the users of the clicker devices, yet they seemed comfortable suggesting solutions to problems with the receiver or the software. This clicker-related problem led to a technology focused exchange between students and the professor that would not have been present in a clicker-less classroom.

In another instance, the business professor asked the class if they knew how to reset the clicker questions because a student raised the point that there were two possible correct answers presented as options. This was a singular 
example of the professor soliciting students directly for help with the clickers. It also demonstrated the students' level of engagement with the clicker question when the student raised the concern that there was more than one correct answer. Following this exchange, the clicker question was not reset and after discussing why there was more than one correct answer the lecture moved forward. In the same class the professor showed a video and as they were setting it up, they again joked to the class, hoping that they would be able to get it to work. The video worked without any problem, but the professor's warning that it might not work was yet another example of how technological discourse was part of the general social interaction in the clicker-enabled class and how reliant the success of that day's lecture was on technology.

The science class demonstrated many of the same challenges with the clickers and also demonstrated similar technological discourse. One of the clicker questions that was observed during the first visit to the science class involved a PowerPoint slide with an image followed by a slide with a clicker question. The students were asked to identify the image and following the clicker question the professor wanted to return to the previous slide with the image on it but was unable to, noting that from past experience, they knew that going back to a slide from a clicker question would most likely result in the computer freezing. In this instance the professor said, "because we know what that does to the clickers" suggesting that the class has experienced clicker problems in the past. Had the class not been using clickers, the professor could have returned to the image slide without consequence. 
The use of clicker technology then, can hinder the ability of the professor to return to earlier information for review purposes. This technological problem promotes a forward momentum in the lecture, which could possibly appeal to digital natives' desire for speed. However, this forward momentum is not likely to be appreciated by all students, especially not those who ask the professor to return to an earlier slide. There are times when speed and pushing forward are not likely to be desirable in classrooms.

The same dilemma of not being able to return to an image slide because of passing a clicker question occurred in the last science class observed, and in this case the professor had to answer a student question without the aid of the image. Towards the end of this lecture, a basic text slide was on the screen but it resembled a clicker question slide. The professor went backwards from this slide but simultaneously realized that it may have been a clicker question and again vocalized concern that the computer might freeze. In both of the classes, there was often a narrative of hesitation about the clickers. Yet this narrative seemed to have a joking tone to it.

\section{Interviews}

In their interviews, both the science and business professors expressed a number of challenges that they faced when using clickers. These challenges were the same for both professors and while the problems were technical, both said that they stemmed from a lack of institutional support for the technology. Both professors were also quick to note however, that the teaching support centre on campus was very supportive of the use of clickers, but that the clicker 
system was not well supported by the computer services on campus. The two main problems identified by both professors were the lack of USB ports in the classroom and the lack of easy access to the TurningPoint software on the classroom computers. Both of these are seemingly minor set-backs, but they actually made using the system quite challenging in terms of incorporating the clicker system with their PowerPoint presentations while maintaining the flow of their classes. The science professor argued that the system needs to be made more "seamless" for them to consider using clickers again in the future.

Both professors expressed that the system, and lack of support for the system, was the problem, and not necessarily the idea of clickers themselves. The set-up at the beginning of class and the numerous times the system did not work, made both professors question whether or not clickers were worth the effort. The science professor said they continued to use them in this class despite the challenges because the students liked them so much, but that they were not sure they would use them again. On the other hand, the business professor said that they worked through the challenges because they were determined to make the clickers work, but when asked if they would use clickers again their response was, "No! Not in a million years.". Based on the interviews, a lack of institutional support is presented as standing in the way of using clickers despite the evidence that students respond favourably to their use.

\section{Surveys}

A few of the survey questions related to the functioning of the clicker system. These questions were dispersed throughout the various parts of the 
clicker section of the survey but are presented together here because they speak to the respondents' thoughts on the clicker system. When presented with the statement "learning how to use the clickers was easy" (see Q1: Easy to Learn, Chart 3.5), thirty-four respondents (62\%) said they strongly agreed while eighteen agreed, three were neutral, and none of the respondents expressed any disagreement with this statement. The majority of both female and male respondents (69\% and $54 \%$ respectively), said they strongly agreed with this statement. Between the two clicker classes, $92 \%$ of the science respondents strongly agreed with this statement compared to $56 \%$ of the business class respondents who strongly agreed and $41 \%$ who agreed.

The results for this statement are a strong indication that the students who responded to the clicker survey could in fact be considered digital natives as demonstrated by the ease with which they adopt new technologies. It should be noted that forty-three of the respondents (all from the business class) had used clickers before, so it is possible that this experience impacted their answer. Though it is also possible that they answered the question by considering the first time they learned how to use clickers in general. Interestingly, despite most of them having experienced clickers in other classes, the business class respondents were much less likely to strongly agree with this statement. Either way, the ease with which these students learned to use clickers demonstrates their level of comfort with learning new technologies. The fact that the students in the business class were using clickers for the first time may account for their generally responding positively to the use of clickers. It is possible that the 


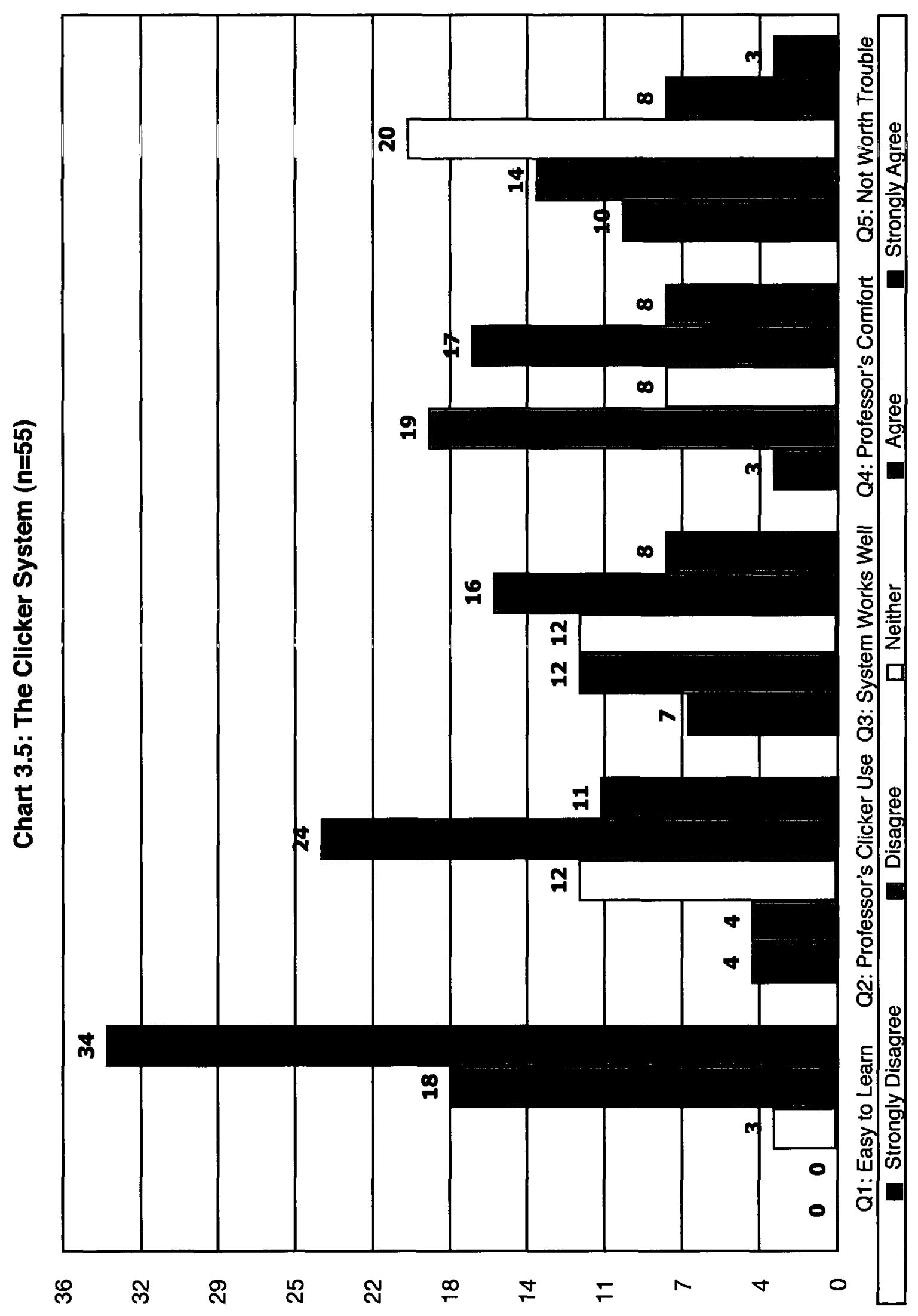


newness of using clickers made them exciting, whereas the majority of the business respondents had previous clicker experience to draw on.

Students were also asked two questions relating to the professor's use of clickers. They were asked to rate the statement "I like the way the professor is using clickers in this class" (see Q2: Professor's Clicker Use, Chart 3.5), and the statement, "the professor seems comfortable with using the clicker system" (see Q4: Professor's Comfort, Chart 3.5). In response to the first statement, only eight students either disagreed or strongly disagreed, while twelve were neutral, twenty-four agreed and eleven strongly agreed. Female respondents were twice as likely to strongly agree with this statement, while males were much more likely to be neutral. The numbers of female and male respondents who agreed, disagreed and strongly disagreed with this statement were similar to each other.

Between the two classes, two-thirds of the science respondents strongly agreed, and the remaining third agreed with the first statement, while there was much more variation amongst the business respondents. In the business class, only $7 \%$ strongly agreed while nearly half agreed, and one quarter were neutral. The remaining business respondents were split between disagreeing and strongly disagreeing. These responses suggest that for the most part, the respondents were pleased with the way the clickers were being used in the class because it is largely up to the professor as to how they are used (how often, anonymously). Liking the way the professor is utilizing clickers is an indication that students like the use of clickers more generally. 
There was more variation in response to the second statement, with nineteen respondents saying they disagreed - suggesting they thought the professor was not comfortable with using the clicker system - while seventeen respondents agreed with the statement that the professor was comfortable with the system. This result seems to reflect the professors' actions within the classroom when, as discussed above, they would often express concern about the functioning of the clicker system. In terms of gender, $35 \%$ of female respondents disagreed with this statement, while a similar amount of male respondents agreed. In the science class, $42 \%$ of respondents strongly agreed, an additional $50 \%$ agreed with this statement, and the remaining $8 \%$ were neutral. This is in contrast to the business class where respondents were much more dispersed in response to the statement about the professor's comfort with the clicker system. In the business class, $45 \%$ of respondents disagreed with this statement while $26 \%$ agreed. These findings suggest that the students in the science class found their professor to be comfortable with the clicker system, while students in the business class were less certain about their professor's comfort level. It is possible that the business professor's occasional joking about the clicker system was interpreted by the business students as discomfort with using clickers.

Finally, regarding the clicker system, students were asked to rate two statements about the general functioning of the system: "the clicker system has worked well (little to no technical problems with the system)" (see Q3: System Works Well, Chart 3.5), and "clickers are more trouble than they are worth" (see 
Q5: Not Worth Trouble, Chart 3.5). A total of twenty-four respondents either agreed or strongly agreed that the system worked well compared to nineteen respondents who either disagreed or strongly disagreed with this statement. Meanwhile, twelve respondents were neutral on this statement. Together, these results demonstrate a level of disagreement about the functioning of the clicker system. Respondents from the science class were mostly in agreement with the first statement that the clicker system worked well. Again, the business respondents were much more varied in their responses to this statement. One quarter of business respondents agreed, and an additional quarter were neutral while $45 \%$ of the business respondents either disagreed or strongly disagreed that the system worked well.

In comparison, twenty respondents were neutral and a combined twentyfour respondents either disagreed or strongly disagreed with the statement that clickers are more trouble than they are worth. In the science class, $67 \%$ of respondents strongly disagreed with this statement and the remaining third disagreed, showing strong support for the use of clickers despite any problems they may have encountered with the system. In the business class $45 \%$ of respondents were neutral, while $19 \%$ agreed and $24 \%$ disagreed that the system was more trouble than it is worth, demonstrating much more variation than the science respondents. However, the overall responses to this statement demonstrate that students do not really seem to mind the technical setbacks related with the clicker system. 
These results are in contrast to the results of the interviews with the professors who both expressed apprehension about using clickers again because of the lack of technical support afforded to them. Previous research on clickers found that the benefits of using clickers far outweighed the challenges (Hoffman and Goodwin 2006; King and Robinson 2009). However, based on the present research, students and professors seem to be on different pages in terms of the functioning of the clicker system.

\section{Summary}

Students seem to be generally in favour of using clickers, yet both instructors seemed hesitant to use clickers again citing a lack of administrative and institutional support for their use. In addition to the support of the students involved in the current research, technologies such as clickers seem to be supported by other authors as a way to support digital native and net generation learners and to further cater to their needs. Clickers support the idea of learnerfocused education (Tapscott 1998) which is advocated for by digital native theorists. This is a moot point however, if instructors are not willing to deal with the challenges of using clickers, because it is up to instructors to introduce clickers into their classrooms in the first place.

Clickers, and the resulting clicker questions have an important presence in the classroom. Using clickers was found to "keep students awake" and to slow down the lecture by presenting periodic breaks. Clickers and clicker questions were also found to have a positive impact on students' levels of understanding, engagement and participation in class. These findings were consistent between 
the genders and the two classes, though there was some variation between these groups. Overall, respondents seem to find clickers to be a welcome presence in their classes.

Beyond interacting with the lecture by using a clicker to respond to clicker questions, students were seen to participate in other ways as well. Most notably, students would often discuss the answers to clicker questions with their peers prior to responding with their clickers. Students were also seen responding verbally when they did not have a clicker, demonstrating that students can engage with clicker questions without the physical clicker.

The results in this chapter also demonstrate support for the argument that clickers can be beneficial in large lecture halls (Mayer et al. 2009). Though it was noted at the beginning of the chapter that students in the science class seemed to ask more questions than the students in the much smaller business class, the respondents from the science class were more likely to agree that clickers aid their participation and involvement in class. Interestingly, there was a lot of variation in response to the statement about clickers helping students feel comfortable participating in class, which serves as an important reminder that there are some things that technology cannot help with. Clickers can enhance inclass participation insofar as they can lead to discussion, but they can also hamper participation when it is assumed that clicking an answer constitutes meaningful in-class engagement and verbal participation does not take place.

The clicker system posed some challenges in both classes, especially from the perspective of the professors who were responsible for setting up the 
system at the beginning of each lecture. Importantly, these challenges were not the result of the professors lacking the skills or knowledge to use clickers, as suggested by Prensky's (2001a) digital immigrant argument. The challenges faced by the professors had to do primarily with physical aspects of using the clicker system which was not well accommodated in the classrooms. Despite the challenges presented by the clicker system however, respondents generally agreed that the benefits of using clickers outweighed the challenges.

The many instances of technological discourse in both classes demonstrate what a large presence the clickers have within each of the two classes. The clickers are not neutral technologies operating seamlessly and invisibly in the background. Instead, they play an integral role in shaping the classroom experience for both professors and students and have a prominent impact on the social interactions in both classes. The clickers are not only physically, but also discursively present in each of the classes observed.

The use of clickers seems to support digital native theory in that they are interactive technologies that can be used to make learning both fun and interactive. The results of this chapter also seem to support the idea that today's students are in fact digital natives in as much as they support the use of technologies such as clickers in their classrooms, and demonstrate a high level of ease and comfort with adopting new technologies. The two classes involved in the clicker research were used because they were accessible - but future research should look at the use of clickers in subject areas that deal with interpretation rather than facts to look at the usability of clickers in these different 
settings. More research should also be done to better account for the gender differences that emerged from the surveys. As a point of comparison to clickers, the following chapter looks at students' in-class laptop use. 


\section{Chapter 4 \\ Digital Notepads or Mobile Distractions?}

This chapter stands in contrast to the previous chapter on clickers and begins to rethink the digital native characterization of contemporary students. While the previous chapter demonstrated support for the digital native characterization of today's students and the argument that digital technologies should be incorporated into classrooms, this chapter on laptops questions this position. The evidence presented suggests that students want the freedom to bring their personal mobile technologies into the classroom but they are less in favour of these technologies being formally incorporated into classroom proceedings.

The chapter begins by considering what digital native theorists have to say about why today's students are bored when in class. The chapter then moves on to look at how often students bring their laptops with them to class. Following this is a review of the various activities - both academic and not - that students are using their laptops for while in class. This chapter concludes with a discussion of respondents' thoughts on the presence of laptops and wireless Internet access in the classroom. This chapter presents the results of a series of survey questions concerning students' use of laptops. The laptop survey was responded to by thirty-three students from two Introductory Sociology classes ( though not all students answered all questions). Of the thirty-three students who participated in the laptop survey, twenty-one were female and twelve were male. There were 
sixteen respondents from one class and seventeen from the other. Data on laptop use collected in the clicker classes is also included in this chapter.

Laptops provide an interesting contrast to clickers. Laptops are brought into the classroom by individual students, who are solely in control of what they do with them, whereas clickers are introduced into the classroom and controlled by the instructor. Laptops can be used for a variety of non-academic activities, while clickers can only be used in conjunction with the lecture. And, most importantly, laptops can create distractions and allow students an opportunity to disengage from the lecture, while clickers are used to keep students focused and involved with the lecture. Laptops are also physically different from clickers. Clickers are small, hand-held devices that can rest inconspicuously on students' desks when not in use, while laptops are larger and have a vertical orientation (Fried 2006), causing them to take up a lot of space in front of the student, and to be visible to others.

One of the primary reasons that digital native theorists argue for more technology in classrooms is that, according to them, digital natives are bored with traditional lecture style classes. Prensky (2001b:5) argues that digital natives like to multi-task because they are so "accustomed to the twitch-speed, multitasking, random-access, graphics-first, active, connected, fun, fantasy, quick-payoff world of their video games, MTV, and Internet". His argument is that because youth today are so used to these conditions in their lives outside of school, schools and educators have to change to meet these conditions, or risk not meeting the learning needs of modern students. 
Tapscott echos Prensky's sentiment that today's students find school boring because they are so used to their stimulating digital lives. He again suggests that the current form of lectures does not fit the needs of net generation students and argues that students want their education to be fun. He further argues that students want to have a say in when, where, what, and how they learn (Tapscott 2009). Based on these arguments, bringing personal technologies into the classroom may be a sign that students are in fact bored with attending lectures. But perhaps this is not the case.

\section{Bringing Laptops to Class}

Survey respondents were asked how often they bring their laptops with them to the class they were surveyed in, and how often they bring their laptops to their other classes. Respondents were presented with the options of 'always', 'sometimes', and 'never'. Regarding how often they bring their laptop to their Introductory Sociology class, respondents were fairly evenly distributed between the three response options. Of the thirty-one respondents who answered the question, eleven said they always bring their laptop to the class they were surveyed in, ten sometimes bring their laptop, and the remaining ten never bring it 5 . Combining the respondents who sometimes bring their laptops with those who always bring it, means that at any given time, up to $64 \%$ of respondents could have their laptop with them in class. This is significant because it means that at times, more students can have laptops with them in the classroom than students

\footnotetext{
5 Two of the respondents who are older than the digital native age range said they always bring their laptops to the class they were surveyed in, and the third said they never bring their laptop to class.
} 
who do not, and the presence of this many laptops is likely to change the classroom atmosphere.

There was much more of a contrast in response to the question of how often respondents bring their laptops to other classes. Nineteen of the thirty-one responded that they sometimes bring their laptop to their other classes. The remainder of respondents were evenly split with six saying they always bring their laptop to their other classes and six saying they never bring it. Between the two sociology classes, the responses were fairly consistent in terms of bringing their laptops to class.

Students in the clicker classes were also asked if they bring their laptops to class, and of the fifty-four students who responded to the question, six bring their laptop to every class, twenty-eight said they bring their laptop to some of their classes, and twenty said they never bring their laptop to class. This means that similar to the laptop classes, $63 \%$ of respondents at least sometimes bring their laptops to class. In the science class, one-third of respondents said they sometimes bring their laptop, and the remaining two-thirds said they never bring it. In comparison, $14 \%$ of the business respondents bring their laptops to every class, $57 \%$ sometimes bring them, and the remaining $29 \%$ never bring them. This suggests that there are features of classes that impact the likelihood that students will bring their laptops to class. It could be that the size of the classroom or lecture hall leads to a sense of anonymity, and students feel that their laptop will go unnoticed. Or, it could be that they are just not interested in the course, but feel that they will learn just by being in the same room as the lecturer. 


\section{In-Class Laptop Activities}

Because of the variety of activities that laptops can be used for, as well as some of the activities seen during the clicker observation, respondents were asked to identify the activities - academic or otherwise - that they use their laptops for while in class. A total of thirty-one students from the two laptop classes responded to this question. The options that students were presented with in the current laptop survey are similar to those used by Fried (2006:909) in a study of student laptop use, though the list in the current research is more extensive than that used by Fried who listed "taking notes, e-mail, instant messaging, surfing the net, playing games, or other" as activities. The students in the two laptop classes participating in the current research were presented with the options displayed in the following table and were asked to select all of the activities that applied to their in-class laptop use.

\begin{tabular}{|l|c|}
\hline \multicolumn{1}{|c|}{ Table 4.1: Laptop Activities } & $\begin{array}{c}\text { Number of } \\
\text { Responses }\end{array}$ \\
\hline Take notes & 27 \\
\hline Follow along with the PowerPoint & 21 \\
\hline Check E-mail & 12 \\
\hline Surf the Internet & 5 \\
\hline Check facebook, Twitter, MySpace, etc. & 10 \\
\hline Watch TV & 1 \\
\hline Watch movies & 2 \\
\hline Watch YouTube videos & 3 \\
\hline Listen to music & 2 \\
\hline Look up what the professor is lecturing about & 8 \\
\hline Play games & 9 \\
\hline Work on assignments & 6 \\
\hline Other (Please Specify) & 2 \\
\hline
\end{tabular}


In the current research, the most popular activity with twenty-seven responses was 'take notes', while the least popular was 'watch TV' with only one response. In the large lecture classes, it is not surprising that respondents say they use their laptops to take notes because, given the small size of the desks, it is not possible to have both a laptop and paper available. In the business clicker class however, it was observed that some students would take notes on paper while having their laptops open for entertainment purposes because they had the room to do so. After note taking, the next most popular response was 'follow along with the PowerPoint' with twenty-one responses. The closeness in the number of responses for note taking and following along with PowerPoint is not surprising since PowerPoint has a built-in note taking capability, making it possible that many students are using the single program for both activities allowing them to seamlessly incorporate their own notes with those on the PowerPoint slides.

After note taking and following along with PowerPoint, there was a drop in the number of respondents who use their laptops for the other activities listed 6 . The next most common activities were checking e-mail with only twelve responses, and checking social networking sites such as Facebook with ten responses. Looking up what the professor is lecturing about received eight responses and playing games received nine. Surfing the Internet was selected by

\footnotetext{
6 For comparison, of the two respondents older than the digital native age range who bring their laptops to class, they both listed taking notes and following along with PowerPoint, while one also checks e-mail, looks up what the professor is lecturing about and works on assignments. Aside from checking e-mail, these activities are related to the class compared to the non-academic activities engaged in by digital native aged respondents.
} 
five respondents and working on assignments was selected by six respondents. Aside from 'working on assignments' which may or may not, all of these activities require wireless access in the classroom. Additionally, checking e-mail and social networking sites can be done in small spurts and is possibly done out of boredom or habit. These two activities may also be accompanied by flashes or sounds on the laptop screen to notify the user the instant there is a new message available for them and Lindroth and Bergquist's (2010) study found that these alerts can be major distractions.

The least popular activities included watching movies, listening to music, and watching YouTube videos. Watching videos on Youtube received three responses and movies and music each received only two. Two respondents selected 'other'. One said that they play poker while in class and the other described using a combination of technologies while in the classroom. This respondent noted that they "take notes on PowerPoints [sic] using a pen digitizer (tablet p.c.), use OneNote, Windows Journal and combine typing and writing in Word", demonstrating a sophisticated use of multiple technologies. Watching movies or YouTube, and listening to music all involve an aural component and require the additional use of headphones which could explain why they are not common in the classroom. Utilizing headphones would make it difficult to listen to even part of the lecture while engaging in other laptop activities. Headphones are also a conspicuous sign that a student is not listening to a lecture. From the front of a class it is not easy to know what a student is using their laptop for, but headphones are visible. 
The majority of both males and females reported taking notes and following along with PowerPoint. Males were more likely to respond that they look up what the professor is talking about, play games, and work on assignments. Meanwhile, females were more likely to check their e-mail and social networking sites such as Facebook. Again, the numbers were quite similar between the two classes, though respondents in one class were more likely to play games and check Facebook.

According to Lindroth and Bergquist (2010), laptop activities can all be considered subordinate to the dominant activity of listening to the lecture. These subordinate activities can be further divided into activities that support learning and activities that serve more of an entertainment purpose. In the current research, note taking, following along with PowerPoint, and looking up what the professor is lecturing about could all be considered subordinate activities that support learning. Additionally, depending on what is being searched, surfing the Internet could be included in this category, as could working on assignments if they are for the class that the student is attending while working on them. All other activities however, have no connection to the dominant activity of listening to the lecture. This means that seven of the twelve listed activities that students are using their laptops for while in class are taking their attention away from listening to the lecture.

These results suggest that while many of the students who bring their laptops to class are using them to take notes, they are also engaging in a variety of other activities simultaneously. According to Prensky (2001b), multi-tasking is 
something that digital natives have become accustomed to because of their multi-media digital lifestyles. He argues that today's students have attention spans for the things they like such as playing video games, but that they are having trouble paying attention in traditional lecture settings because they lack the level of interactivity and feedback that students are accustomed to. In regards to being bored, Lindroth and Bergquist (2010:315) found that students reported that their laptops were used as a way to make it through what they found to be a boring lecture. It is perhaps the case then, that students bring their laptops to class so that they can purposefully multi-task and redirect their attention.

\section{Laptops and Wireless Internet in the Classroom}

Regardless of whether or not they bring their laptops with them to class, respondents were asked to rate their level of agreement with five statements about the presence of laptops in their classes. These five statements could be answered by all respondents because they were opinion-based statements that ranged from whether or not laptops should be allowed into the classroom, to whether or not students should be required to purchase laptops. The thirty-two respondents who answered this question were rather dispersed in response to these statements.

When presented with the statement "students should be required to purchase and use laptops for school", thirteen respondents disagreed and an additional twelve strongly disagreed with this statement. Six respondents said they neither agreed nor disagreed that laptops should be required and only one respondent said they somewhat agreed with this statement. This suggests that 
while a number of students bring their own personal laptops with them to class, they do not want to be required by the school to purchase and use them. Additionally, as will be seen in the next chapter, all survey respondents own a personal computer - either desktop or laptop - without being required by the institution to do so. Owning a computer has likely become an unstated requirement of attending a post-secondary institution.

Respondents also disagreed with the other extreme. In response to the statement "laptops should not be allowed in classrooms", twelve respondents disagreed and an additional twelve strongly disagreed. Five respondents were neutral in regards to this statement and three said that they somewhat agreed. The majority of students who disagreed and strongly disagreed with this statement were students who at least sometimes bring their laptops to class, but there were also some students who never bring a laptop that disagreed with this statement. Again, this suggests that students do not want to be limited in the use of their laptops nor do they think that their peers should be limited, but that they want the freedom to use them as they please.

In response to the statement "using laptops in the classroom is distracting", respondents were a bit more dispersed in their answers. Three respondents said they agreed with this statement and an additional thirteen said they somewhat agreed. There were six respondents who said they neither agreed nor disagreed that laptops are distracting in the classroom. Seven respondents said they disagreed and only three said they strongly disagreed with this statement. Given the varying numbers of students who bring their laptops to 
class and the ability of students to choose where they sit to try and position themselves in the classroom so that they will not be distracted, it is probably not surprising that respondents are so divided on whether or not laptops in the classroom are distracting.

There was not a direct correlation between bringing a laptop to class and finding laptops distracting, though the students who never bring their laptops were more likely to agree than disagree that laptops are distracting. Perhaps not surprising, the three students who agreed that laptops are distracting also said that they never bring a laptop to the class they were surveyed in. Conversely, the students who strongly disagreed that laptops are distracting were students who at least sometimes bring their laptop to class. However, there was more variation in the students who somewhat agreed with this statement with five respondents saying they always bring their laptop, while five others said they never bring a laptop to class.

These results suggest that students recognize that laptops are distracting, but some choose to bring them to class anyway. It is also possible that students bring their laptops to class for this very reason, and that some students may not find the distraction provided by laptops to be a negative. In Fried's (2008) study, other students' laptops were found to be the primary distraction reported by students, but in the current study, students do not seem to be as adamant that laptops are distracting in the classroom. And, as shown by the responses to the earlier statement, respondents do not think laptops should be banned from 
classrooms, further suggesting that laptops are an accepted distraction within the classroom.

Respondents were most similar in their responses to the statement "wireless Internet should be available in classrooms". This supports the findings from McMahon and Pospisil's (2005) study that students want around-the-clock wireless Internet access because the Internet is a primary source of information both inside and outside of school. Nineteen respondents agreed with this statement and an additional four said they somewhat agreed. Five respondents were neutral regarding the availability of wireless Internet while three disagreed that it should be available and one strongly disagreed that wireless Internet should be available in classrooms. In light of the earlier question about the different activities students use their laptops for while in class, it is not surprising that so many respondents think wireless Internet should be available in classrooms. Between five and eight of the activities listed in the earlier question are dependent on Internet access and they are all - excluding looking up what the professor is lecturing about - subordinate activities that are not related to the class. This further suggests that students want the freedom to bring their own personal laptops to class and to do with them what they please.

The final statement that students were presented with was "laptops should be incorporated into the lecture". Only one respondent agreed with this statement while two more said they somewhat agreed. Eleven respondents were neutral in response to this statement, twelve disagreed and six strongly disagreed. This is 
supported by another question that was part of the laptop survey asking students about the types of activities they would like to take part in during class.

When presented with "Internet research using a laptop and wireless access" as a possible classroom activity, only seven of thirty-one respondents selected this as a way they would like to engage in class. This supports the findings in the activity question that students are using their laptops for various non-academic activities while in the classroom. Students want Internet access and the freedom to bring their laptops to class but do not want to be told when and how to use them. It appears as though students may be resistant to having their digital devices that are primarily used for entertainment and communication, used for 'work' purposes instead. This could be demonstrative of Prensky's (2001a) argument that digital natives prefer games and play over work. Rather than having their entertainment technologies incorporated into the lecture to make the lecture more 'fun', it is perhaps the case that students would prefer to keep their 'fun' and 'work' distinct and separate.

\section{What is Going on Behind the Screen?}

From the front of the classroom, it is difficult to know what activities students are engaging in when their laptops are open in front of them because all that can be seen is the back of the laptop. There may be some visual cues that the student is not paying attention to the lecture, but on the whole, it cannot be determined if the student is taking notes, playing a game, or both. However, while observing the business and science classes for the clicker portion of this thesis, I was positioned at the very back of both classrooms and therefore had a view, not 
only of the use of clickers, but also of the personal technologies that students were using while in class. Because of their size, laptops were the most obvious personal technology present in the classrooms but students were also seen using their cell phones and mp3 players while in class.

As demonstrated in the above survey question on laptop activities, students were often engaged in non-class activities while using their personal technologies. This was especially present in the business class where students often had their laptops open in front of them during class. In contrast to this, very few students seemed to bring their laptops to the science class, and the students that were observed with laptops would typically have them open before class and close them as the lecture began. It would be interesting to know if these trends apply to business and science classes generally, or if there were features about the two classes observed that caused these differing laptop behaviours, but this cannot be determined from the unobtrusive observation that was conducted.

In the business class, the students who had laptops open seemed to use them for multiple activities. Some students were observed taking notes on their laptops but students were also observed playing games such as solitaire and one student was observed playing with a photograph manipulation program. Some students would use their laptops for games while taking lecture notes with pen and paper - switching back-and-forth between digital entertainment and analogue work as they saw fit. This is further evidence that students are perhaps resistant to having their digital entertainment devices commandeered for 'work' use. Laptops are capable of running 'fun' and 'work' operations at the same time, 
yet some students chose to keep the two activities separate. In the business class some students would also play games on their cell phones or mp3 players while also taking notes on paper.

Cell phones were present in both classes and many students would have them out on their desk in front of them throughout the class. Cell phones seem to have become so mundane that they are placed on students' desks as if they are nothing more than a pen or eraser. Compared to laptops, cell phones are closer in physical characteristics to clickers, making them even more mobile than laptops because of their small size. Unlike clickers however, cell phones are under the control of the student and can be used at will for a variety of activities from playing games, to sending text messages.

Cell phones also make sounds, meaning that beyond the visual distraction that may be caused by a student using their cell phone, there are often aural distractions caused by cell phones as well. In the business class, a student was observed checking their phone to see who had just called after the phone was vibrating on their desk, and in the science class a student spent an entire lecture playing with their phone which often resulted in the phone making sounds. When the phone in the science class was making sounds it prompted other students to reach for their own cell phones. By being distracted by the sounds of this one cell phone, these students created further visual distractions by moving around to reach for, and check their own cell phones. There were also instances of students seen to be sending text messages during class. This activity can be silent and relatively quick, but it is also easily observed because while students 
may or may not be taking notes on their laptops, they are most surely not taking notes on their cell phones.

Both Prensky (2001a) and Tapscott (2009) argue that connectivity is a defining feature of digital natives and the net generation. Students seen sending text messages and checking missed calls while in class appear to demonstrate this characteristic. It is as if some students cannot make it through even an hour and a half without some form of contact beyond the classroom. Prensky (2006) even argues that, more than laptop computers, educators should be finding ways to incorporate cell phones into their classroom activities because so many students have them and they are becoming increasingly multi-purpose. However, if the use of personal technologies observed in this study are any indication, students may show resistance to having their cell phones used for educational purposes.

\section{Summary}

The prevalence of multiple personal technologies in the classrooms observed demonstrates that on some levels, today's students are living very digital lives. They own a variety of mobile digital technologies and use them for a variety of - mainly non-academic - activities. Based on the two observed classes however, students have not left the analogue world behind entirely. Many, for example, still take notes with pen and paper. The students from the laptop survey classes also demonstrate that while some students bring their laptops with them to class, there are also students who never do. 
The findings in this chapter suggest that students want the option of bringing their laptops to class and using them for a range of activities - lecturerelated or otherwise - that they feel like engaging in while there. Students do not want to be told when and how they can use their laptops, and they want access to the Internet while in class. These opinions were shared by students regardless of whether or not they bring their own laptops to class suggesting that there is an overarching sense among respondents that they should be afforded the freedom of choice.

Males and females responded similarly to most of the questions on the laptop survey, though there were some areas where they differed. Regarding wireless Internet in classrooms, $84 \%$ of male respondents agreed that access should be available in classrooms, compared to only $41 \%$ of the female respondents. However, female respondents were slightly more likely to report bringing their laptops to class. Perhaps more males would bring their laptops to class if there was wireless Internet access. It is possible however, that there are reasons beyond Internet access that influence why males and females bring their laptops to class.

With the variety of activities that they use their laptops for while in class, it is understandable that many students find laptops in the classroom to be distracting. The physical characteristics of laptops such as their size, their vertical orientation, and their dynamic screens, can make them distracting not only to the individual user, but also to those around them. Yet, laptops seem to be a distraction that students are accepting of since most of them disagree that 
laptops should be banned from the classroom altogether. This further suggests that beyond owning and using digital technologies, a sense of freedom and choice may be a unifying feature of contemporary youth. According to Tapscott (1998), fierce independence is a defining feature of the net generation. It is possible however, that this sense of independence could be attributed to causes other than access to digital technologies, but determining this is beyond the scope of the current research.

The desire to have laptops and wireless Internet in class supports the digital native characterization of today's students in as much as it suggests that they want constant connectivity and they seem to be multi-tasking. However, there is less support for the digital native argument that technologies need to be further incorporated into teaching and learning. The students in the current study do not generally support mandatory ownership of laptops and they do not generally want laptops to be incorporated into their classes. To further complicate the discussion of whether or not today's students are in fact digital natives, the following chapter looks at the results of survey questions on educational expectations and the limits of technology in the classroom. 


\section{Chapter 5 \\ Digital Technologies and Educational Expectations}

In contrast to the chapters on clickers and laptops, this chapter addresses students' expectations of technology in their university education more broadly and combines the results of a series of questions that were on both the clicker and laptop surveys. Between the two surveys, a total of ninety-one students responded to these questions (though not all respondents answered every question). Both surveys featured a succession of questions about students' ownership of personal technologies such as computers, cell phones, and $\mathrm{mp} 3$ players. Additionally, the surveys both concluded with questions about students' expectations for their undergraduate education and how technology factors into these expectations and their classroom experience.

Clickers and laptops are employed as examples of technologies that are being utilized in university classrooms but they are by no means the only technologies present which is why students were also asked about other technologies. The goal of these survey questions was to get a sense of what technologies students own and use in their everyday lives, and whether or not any of these technologies are being used for academic purposes. An attempt was also made to gauge the types of technologies that students are already using in relation to their education, and more importantly, which technologies are being used for which educational activities.

The results of these survey questions are presented in this chapter beginning with a look at the personal technologies owned by respondents. 
Following that is a discussion of the skills and capacities that survey respondents said they wanted to gain from their university education as well as a look at the technologies they are using in the development of these skills. Lastly, this chapter looks at the types of activities and technologies respondents would like to see more or less of in their university classrooms.

\section{Digital Classrooms for Digital Natives}

Digital native theorists argue that because contemporary youth are surrounded by digital technologies in their daily lives, they therefore want more technology in their classrooms. More extremely, some digital native theorists argue that the lack of technology in schools means that the current education system is failing to meet the needs to today's youth. In his 1998 book Growing Up Digital, Tapscott argues that the education system needs to shift from the old 'broadcast' format to the new 'interactive' approach to educating. Tapscott makes eight suggestions for how this shift can be achieved including moving 'from linear to hypermedia learning', 'from instruction to construction and discovery', and 'from the teacher as transmitter to the teacher as facilitator' (142-148). These three shifts contribute to five others which, if implemented, would involve fundamental changes to the education system.

The five main changes that would lead to the paradigmatic shift advocated by Tapscott include moving 'from teacher-centred to learner-centred education', 'from absorbing material to learning how to navigate and how to learn', and 'from one-size-fits-all to customized learning'. Further, Tapscott argues for a move 'from learning as torture as [sic] learning as fun', and lastly, 'from school to 
lifelong learning' (1998:142-148). These shifts, according to Tapscott, need to happen in order for the education system to meet the learning needs of the net generation. He argues that without the move from the broadcast system to the interactive approach, the net generation will not be able to succeed.

This chapter presents a somewhat different picture of what today's youth want from their education. In direct contrast to the argument that students want and need their education to be digitally enhanced, the survey results discussed in this chapter suggest that students prefer a moderate amount of technology to be used in their classrooms. Additionally, students demonstrate some resistance to use their own personal technologies for education purposes. It is perhaps the case that rather than shifting from the broadcast system of lecturing to the interactive approach to teaching, an attempt to combine the two would better serve the educational needs of contemporary students.

\section{Ubiquitous Personal Technologies}

In addition to being asked about their ownership of personal technologies, respondents were asked to rate their level of comfort with technology on a scale from 'very uncomfortable' to 'very comfortable'. This question was designed to be broad and therefore did not specify any particular technologies, meaning that it was left to respondents' interpretations. In total, eighty-seven respondents answered this question. Interestingly, five respondents said they were 'very uncomfortable', two responded that they were 'uncomfortable' and three said they were 'neither comfortable nor uncomfortable' with using technology. If being comfortable with technology is one of the basic characteristics of digital natives, 
then these responses would suggest that not all of the students who participated in this research can be considered digital natives.

The vast majority of respondents however, indicated that they are either 'comfortable' (thirty-five) or 'very comfortable' (forty-two) using technology. This means that $89 \%$ of respondents expressed a level of comfort with using technology. Notably, almost half (48\%) of the respondents said they were 'very comfortable' using technology. However, while this is a large proportion of the small sample involved in this study, it does indicate that not all students are comfortable with using technology. The $89 \%$ of respondents who indicated that they are comfortable using technology cannot be seen to represent the respondents who said they were not comfortable.

On both the clicker and laptop surveys, males were more likely than females to report being very comfortable using technology. This is consistent with the commonly held belief that males possess greater technical skills than females. It is not possible to know however, if respondents were confirming this stereotype, or being influenced by it, when answering this question.

Being comfortable with technology could be in part, a result of owning technology and respondents were therefore asked about some of the personal technologies they own. Participants were asked if they own a computer, and if they do, whether it is a laptop or a desktop. Perhaps not surprisingly, every participant who answered this question owned a computer. Some students indicated that they own both a laptop and a desktop computer, fourteen answered that they own a desktop, and the majority of participants (eighty-three) 
indicated that they own a laptop. Computers, and laptops in particular have, in the past few year, come to be seen as a necessity for post-secondary education and many students look at buying a laptop as an extension of paying tuition. With this many students owning laptops, it is not all that surprising that so many students are bringing them into the classroom.

In addition to being asked about computers, respondents were asked whether or not they own a cell phone. Again, this finding was not all that surprising with eighty-two of the ninety respondents answering that they do own a cell phone. As a follow up to this question, respondents were asked whether or not their cell phones were smartphones. Smartphones are unique from standard cell phones because of their advanced computer-like functions; examples of smartphones include the iPhone and Blackberry.

Students were asked if they owned smartphones because the company that makes the clickers used in this study also make a smartphone application, meaning that with a subscription, students can use their own smartphones as a clicker. If there are a majority of students who own smartphones, then implementing the use of clickers could be easy to achieve on a large scale since fewer clicker devices would need to be purchased. And, since it would mean using a technology students already own, they may be more likely to participate. However, of the eighty-two cell phone owners only twenty-eight, or one-third, said they owned smartphones, while fifty-four did not. Smartphones are relatively new, and their cost can be prohibitive, but as prices go down more students may purchase them, and more educational uses may be created. 
Finally, respondents were asked if they own an iPod or other mp3 player, and if so, do they ever use it for educational purposes. Again, mp3 players are a popular personal technology that also has potential educational uses. In particular, during previous research on educational technologies, the use, benefits, and challenges of educational podcasting was found to be a popular area of research 7 . In the current research, seventy-nine of eighty-seven respondents said they owned either an iPod or mp3 player, while only eight did not. However, very few of those who own these technologies are using them for educational purposes. Eighty-five respondents answered the question about whether or not they use their mp3 player for educational purposes, and only five of them said 'yes'. This question also asked that students specify what educational activities they use their mp3 players for, if any. There were five written responses to this question including one student who simply listens to music on their mp3 while they study, and another student who downloads VOD [video on demand] and podcast lectures. These few examples suggest that there are a number of potential educational uses for $\mathrm{mp} 3$ players but a majority of students do not seem to associate these technologies with education, probably because they are marketed as entertainment devices.

Due to the universality of these personal technologies, there was essentially no variation in patterns of ownership between males and females or across the participating classes. These survey findings demonstrate that for the vast majority of respondents, technology is very much a part of their everyday

\footnotetext{
7 For example see McKinney, D., Dyck, J.L., \& Luber, E.S. 2009. "iTunes University and the classroom: Can podcasts replace Professors?" Computers and Education, 52, 617-623.
} 
lives. Importantly, these technologies (excluding desktop computers) are all mobile, making them very easy for students to bring to campus, and subsequently, into the classroom. What these findings also demonstrate is that, for the most part, the students who responded to the survey are not actually using these technologies as part of their university education. However, as was observed in the clicker portion of the research, these technologies are making their ways into classrooms, though seemingly for non-academic purposes. However, during the research, many instances of the above mentioned technologies being used for educational purposes were encountered, so the potential is there if either educators or students are inclined to use these technologies for educational purposes.

\section{Skills, Capacities, and Technologies}

In order to better understand the technologies students are using in conjunction with their education and how they are being used, it is first important to better understand what students expect from their university education. It is also a goal of the research to encourage students to critically examine their educational expectations as well as the role of technology in their education. With this in mind, students were asked to select all that applied to them from a list of skills and capacities that they wish to develop while at university. The skills and capacities listed were, 'essay writing', 'verbal skills', 'critical thinking', 'information finding (research skills)', 'group work', and 'other (please specify)'.

'Critical thinking' was the most commonly selected option with seventythree respondents choosing it. Following this, the majority of students selected 
'information finding (research skills)', and 'verbal skills'. 'Essay writing' and 'group work' were rated almost equally with forty-five and forty-three responses respectively, while 'other' was selected by only five respondents. Respondents were asked to indicate the 'other' skills they hoped to gain from their university experience but only three did so. One responded that they would like to develop "math and physics" skills, one listed "time management, extracurricular, social networking", and the third said they wanted to develop "skills and 'smarts' that pertain to my future career". Because so few students selected 'other' and only three listed what they meant by 'other', the rest of this section focuses on the five skills that were listed on the survey.

After identifying the skills and capacities they hoped to develop, students were asked to rate how important technology was in the development of each skill and capacity. Respondents were presented with a three-point scale ranging from 'not at all important' to 'somewhat important' to 'extremely important'. The results of this question can be seen in Chart 5.1.

Participants were quite divided on the importance of technology to the development of these skills and capacities, with the exception of 'research skills', which they almost unanimously agree on. For each skill, the majority responded that technology was either 'somewhat important' or 'extremely important' to the development of that particular skill. In terms of 'research skills', the almost unanimous response that technology is 'extremely important' is probably not surprising given the dependence on the Internet as a primary source for information. Some of the other responses are surprising however. 
Chart 5.1: Importance of Technology

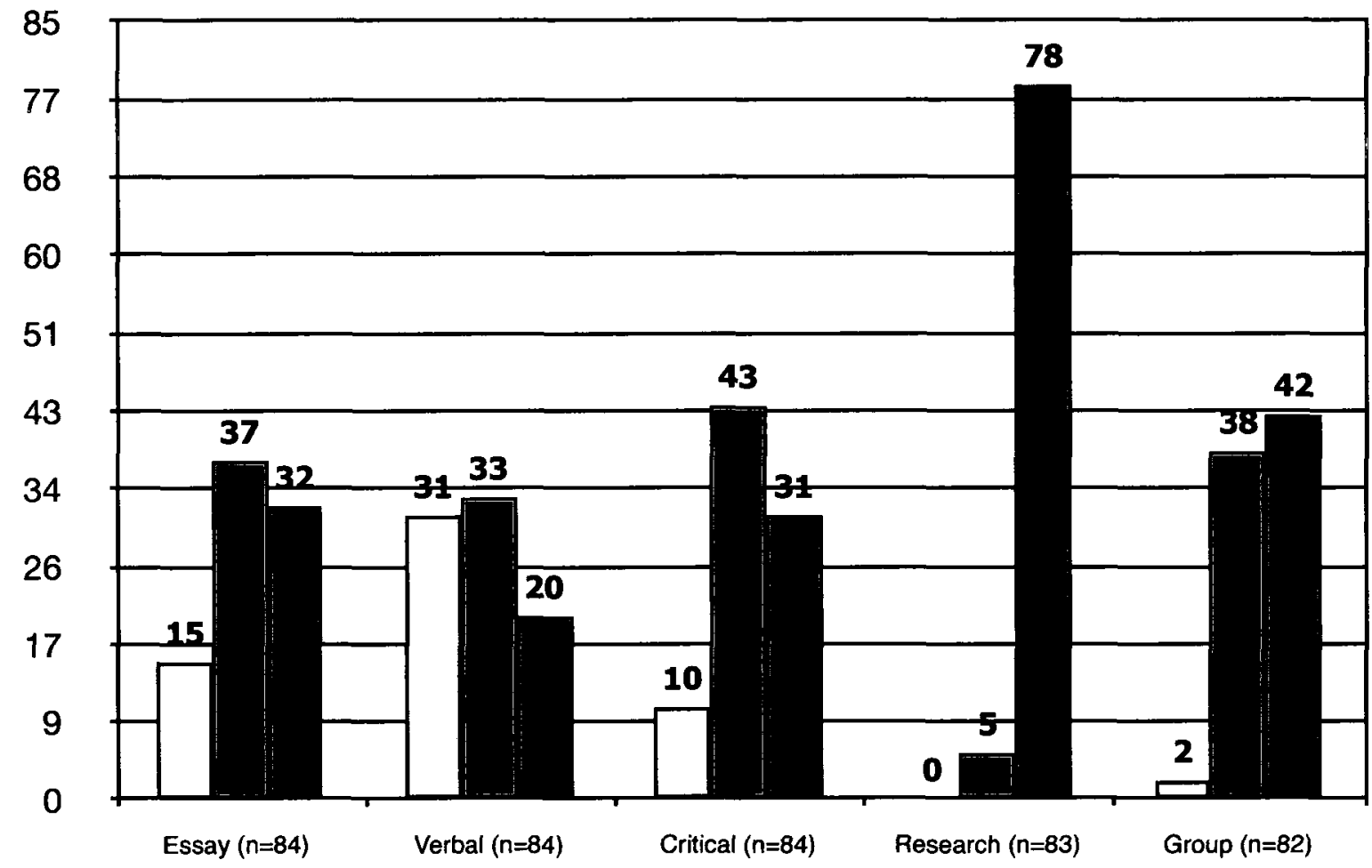

$\square$ Not Important $\square$ Somewhat Important $\quad$ Extremely Important

Respondents were split on the importance of technology to the development of essay writing skills. This was at first glance surprising given that students are almost always required to hand in word processed essays, making the production of essays dependent on technology - in this case computers. Upon further consideration however, it may be the case that students recognize that the actual skills and capacities (excluding typing) to write an essay are in fact not dependent on technology at all. Students can, and do, learn skills such as grammar, and essay structure without technological aid.

It is also possible that because computers are so ubiquitous in students' lives that they do not consider them to be technologies. Tapscott (1998:39) 
argues that this is in fact the case, noting that technology is largely "transparent" to members of the net generation in the sense that they often see past technology to "the people, information, games, applications, services, friends, and protagonists at the other end". This may explain why the numbers of respondents who said the Internet is important to their education did not match the number who said the computer was important. There seems to be a distinction between the importance of the content made available by the technology and the technology itself.

In comparison to the responses to essay writing, the responses to the importance of technology to the development of critical thinking were surprising for the opposite reason. Forty-three respondents said technology was 'somewhat important' while thirty-one said it was 'extremely important' to the development of critical thinking. Upon initial consideration, technology does not seem to play any part in the formation of critical thinking skills. However, it is possible that students consider critical thinking to be connected to information finding and research skills. It is also possible that students connect the development of critical thinking with sorting through the abundance of mass media they encounter on a daily basis. Tapscott (2009:80) argues that one of the characteristics of the net generation is that they are "scrutinizers" because of their exposure to so much "unreliable information" on the Internet, "today's youth have the ability to distinguish between fact and fiction". Critical thinking may be a skill students have developed on their own, outside of the classroom because of its importance to their daily lives. 
Respondents were most evenly divided on whether or not technology was important to the development of verbal skills. Almost as many respondents said technology was 'not at all important' (thirty-one responses) as said it was 'somewhat important' (thirty-three). It is possible, that respondents find technology at least 'somewhat important' to the development of verbal skills because of their use of technology for communication, but that they also recognize - much like essay writing - that this skill can be developed without technological aid.

The response to the importance of technology to group work is perhaps the least surprising because of the use of technology by students as a way to stay connected to their friends and peers. As was seen earlier in this chapter, almost all respondents own a cell phone and computer meaning that they have around the clock access to communication technologies. Both Prensky (2001a) and Tapscott (2009) argue that one of the distinguishing features of digital native youth is that they thrive when they are able to network and collaborate. Using the personal communication technologies they already use in their daily lives to connect and communicate for educational purposes seems to support this characteristic of digital natives.

What is evident from this question is that respondents find technology to be at least 'somewhat important' to the development of a number of skills in their university education. This is in contrast to the digital native theorists who would argue that youth find technology to be 'extremely important', and even vital to their education. This question looked at technology broadly but it did not indicate 
which technologies were important to the development of each skill. As a follow up, respondents were asked to indicate all of the various technologies they use in relation to their education more generally. And lastly, students were asked which technologies they use in relation to the specific skills and capacities listed.

Students were presented with a list of eight technologies including 'computer', 'television', 'Internet', 'iPod/mp3', 'E-mail', 'WebCT', 'instant messaging', and 'social networking sites', as well as an option of 'other'. As discussed in the introductory chapter, computers and mp3 players, are physical technologies, while the Internet, e-mail, WebCT, instant messaging and social networking sites, are ICTs. Television on the other hand, is considered an analogue technology though it is becoming increasingly digital. The three technologies most commonly selected by the eighty-four respondents who answered this question were computer (eighty-two responses), Internet (eightytwo responses), and WebCT (eighty-one responses). These three technologies work together, and with the importance that many courses place on WebCT as a source of information and communication for students, it is probably not surprising that so many students listed it as being part of their education. WebCT is dependent on the Internet, which is accessed through a computer, meaning that the three are inherently linked.

The next most popular technology was e-mail which was selected by seventy respondents, followed distantly by instant messaging and social network sites which were selected by thirty-six and thirty-two respondents respectively. These are all communication technologies, the last two of which are more 
commonly associated with leisure and entertainment than education. Probably also used for communication, two respondents listed 'texting' as 'other' technologies that they use as part of their education.

Television and $\mathrm{iPod} / \mathrm{mp} 3$ were the least popular responses with twenty and a mere eight selections respectively. Many of the respondents who listed television are probably enrolled in at least one CUTV (Carleton University TV) class, while the lack of respondents listing iPod/mp3s confirms the earlier finding that students do not use these particular technologies for educational purposes. Much like instant messaging and social networking sites, television and iPod/mp3 players are probably more likely to be associated with entertainment than with education. Aside from texting, one respondent listed "youtube", and another student discussed their combined use of a tablet and desktop computer as 'other' technologies they use as part of their educations.

Having established the skills and capacities respondents want to develop through their university education, and how important respondents think technology is to their general education and the listed skills and capacities in particular, respondents were then asked to indicate which of the technologies they used in relation to each of the skills and capacities. The number of respondents who answered this question varied for each skills as can be seen in Chart 5.2. Along with the technologies listed in the previous question, respondents could answer 'other' or 'none', though these options were rarely selected. The results of this question mirror the responses to the earlier questions about which technologies they are using as part of their education. 
Computers, the Internet, WebCT and e-mail again appear to be especially important technologies even when looked at across the various skills and capacities. Across the five skills the Internet was the most commonly selected, computers were a close second, WebCT came in third, and e-mail was a close fourth. As was discussed earlier, these four technologies are all closely related with computers being the access point for the Internet, and WebCT and e-mail both being web-based technologies.

In terms of essay writing, computers were selected by sixty-nine respondents, and Internet by fifty-nine. Following computers and Internet were WebCT with only twenty-eight, and e-mail with twenty responses. The least important technology for essay writing was the iPod/mp3 player with only one selection. Television, instant messaging, and 'none' were each selected by about five respondents. Computers and the Internet appear to be by far the most important technologies for the development of essay writing skills and capacities.

Just as respondents were divided on the overall importance of technology to the development of verbal skills, they were divided on which technologies were most important for developing this skill. The Internet, computers, and television all received a similar number of responses. Interestingly, twenty-two respondents selected 'none' for this skill, which was the most for any of the five skills listed. This is reflective of the findings of the earlier question about the overall importance of technology to the development of verbal skills. There seems to be recognition amongst respondents that verbal skills can be developed without any technological aid. Instant messaging and e-mail received twenty-two and twenty 
responses respectively, which is probably not surprising given their importance as means of communication. Again, the iPod/mp3 player was the least important with only five responses.

The Internet appears to be the most important technology for the formation of critical thinking skills with sixty-one responses. Computers are second with fifty-three selections. WebCT is a distant third with thirty-six selections. The number of respondents who selected WebCT is bit perplexing because WebCT is designed to be a source or location for course content and communication and does not at first glance appear to have any relation to developing critical thinking skills. E-mail was next most important with twenty-four responses, and television followed with nineteen. Much like WebCT, the number of respondents who selected e-mail as being important to developing critical thinking skills is a bit surprising, because it is not immediately clear how e-mail develops critical thinking skills.

Closely related to critical thinking, the responses to the technologies used to form research skills were quite similar. The Internet and computers were again the first and second most important technologies with sixty-seven and sixty-four responses respectively. WebCT was third with forty selections, which makes sense given that courses' WebCT pages often contain assignment-specific resources to help students with their research. E-mail and television were again fourth and fifth most important with twenty-seven and twenty-five selections respectively. 


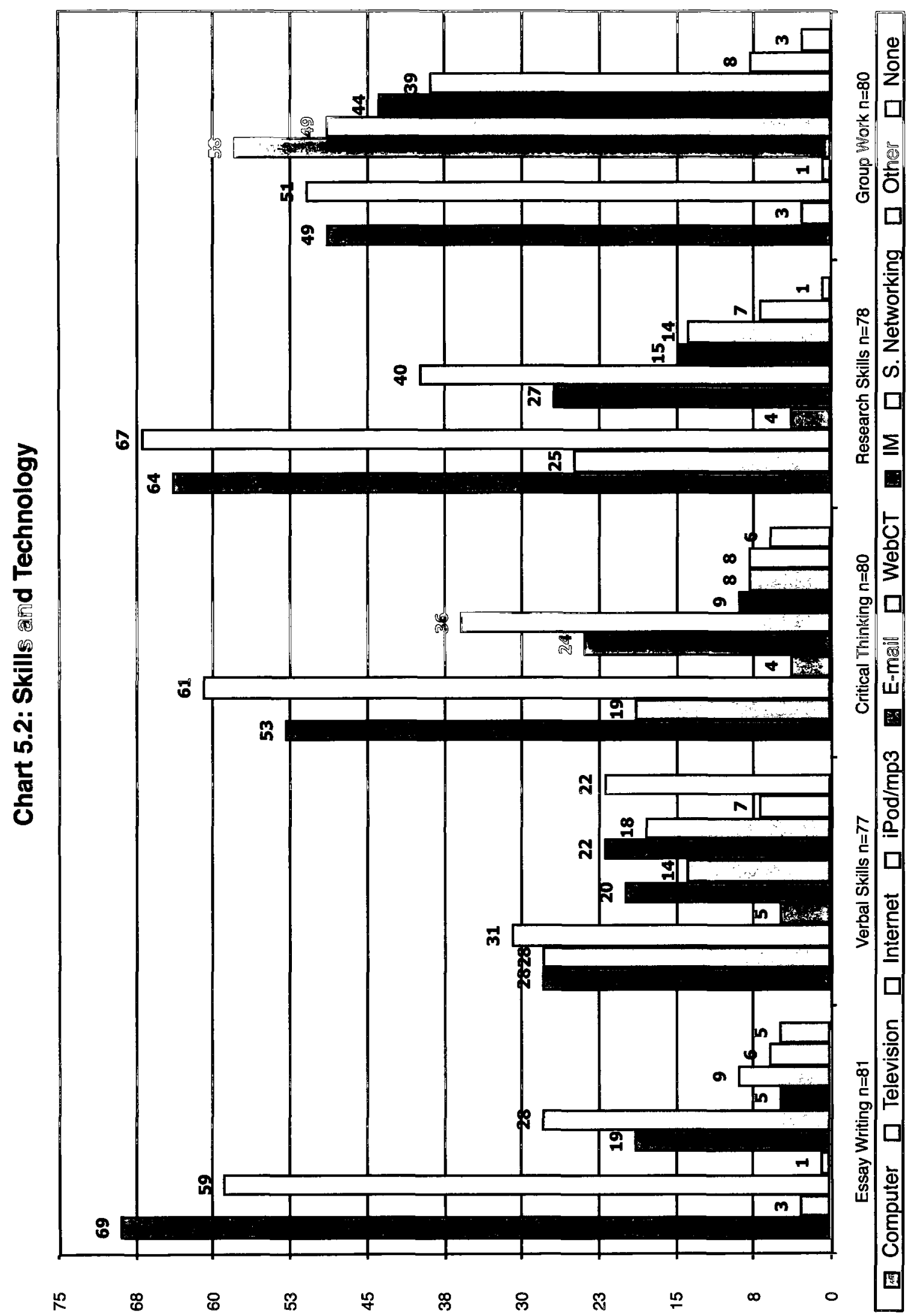


Understandably, the communication technologies were the most important for group work. E-mail was selected by fifty-eight respondents, the Internet by fifty-one, and computers and WebCT were each selected by forty-nine. Instant messaging was the next most important with forty-four responses and social networking sites followed with thirty-nine. These digital web-based communication technologies are widely used by youth to connect with friends, family and even strangers, so it is understandable that they would turn to these technologies to connect with their school peers when necessary.

When the three questions about the importance of technology are taken together, it is evident that respondents find the Internet to be the most important technology regarding their education. The Internet can be conceived as both a place where information can be found, and a space where communication can take place. The Internet also makes these actions possible beyond the classroom and campus. Furthermore, the Internet is the means through which many of the other technologies are possible including e-mail, WebCT, instant messaging, and social networking sites. Interestingly, some of the numbers suggest that computers are not quite as important as the Internet, yet they are essentially a prerequisite for the use of the Internet. It is perhaps the case that because computers are so ubiquitous in respondents' lives (they all own at least one) that they are taken for granted or that they are assumed when respondents select the Internet as being important. 


\section{Digitally Enhanced Classrooms?}

Beyond the questions about skill development and technology, respondents were asked about the use of technology within the classroom. The clicker and laptop surveys contained variations of two questions on this topic. The first question was about the limit of technology that respondents were comfortable with in the classroom and the second was about the classroom activities they would like to see more or less of.

Students were presented with a series of options and were asked to answer the question "Is there a limit to the amount of technology you would be comfortable with in the classroom? Choose all that apply.". As can be seen in the table below, the options ranged from a technology free lecture, to earning their entire university degree online. The clicker class had one additional option which read "Lecture with PowerPoint slides and clickers", and came after the option of "Lecture with PowerPoint slides". This question was answered by eighty-seven respondents between the two surveys.

\begin{tabular}{|l|c|}
\hline \multicolumn{1}{|c|}{ Table 5.1: Amount of Technology in the Classroom } & $\begin{array}{c}\text { Number of } \\
\text { Responses }\end{array}$ \\
\hline Prefer just a lecture with no technological aids & 13 \\
\hline Lecture with PowerPoint slides & 56 \\
\hline Lecture with PowerPoint slides and clickers & 35 \\
\hline Watch the lecture via video in a classroom & 8 \\
\hline Watch the lecture online but write tests or exams in the classroom & 14 \\
\hline Conduct class entirely online & 8 \\
\hline Earn your entire degree online & 3 \\
\hline
\end{tabular}

In the clicker classes, "Lecture with PowerPoint slides and clickers" was the most commonly selected with thirty-five responses. In the laptop classes, 
"Lecture with PowerPoint slides" was most common with twenty-six responses, while in the clicker classes this option was chosen by an additional thirty respondents. This is not surprising given that using PowerPoint has become standard in undergraduate lectures (this format was used in the four classes that were surveyed) and respondents are therefore familiar with it. These responses suggest that respondents are generally pleased with the status-quo, and may be resistant to greater levels of technology being incorporated into their classroom experience (or removing their classroom experience entirely).

The least popular option was 'Earn you entire degree online” which was selected by only three respondents, all of whom came from the clicker classes ${ }^{8}$. In comparison to this, the other extreme - the technology free lecture - was chosen by thirteen respondents. The option to "Conduct class entirely online" was only selected by eight respondents. So, while respondents would prefer no technology to an entirely online degree or classroom, they generally seem to prefer a moderate level of technology in the classroom. And, not only do they prefer moderate amounts of technology, but they prefer the level of technology they are currently experiencing. Amongst respondents, there does not appear to be a desire for greater levels of technology to be used within the classroom, which is in stark contrast to most of the digital native theory.

Following the question about the limit of technology in the classroom participants were asked about the types of activities they would like to see more or less of in their classes. More specifically, they were asked "In terms of

\footnotetext{
8 One of the laptop class respondents who is older than the digital native range also selected this option, but their response was removed from the general data reporting.
} 
engaging in class are there activities that you would prefer? Choose all that apply.". There were five activities provided with the addition of "other (please specify)", and on the laptop survey there was also the option of "Internet research using a laptop and wireless access". Between the two surveys, a total of eightyfour respondents answered this question.

\begin{tabular}{|l|c|}
\hline \multicolumn{1}{|c|}{ Table 5.2: Classroom Activities } & $\begin{array}{c}\text { Number of } \\
\text { Responses }\end{array}$ \\
\hline Small group discussions & 29 \\
\hline Writing tests & 17 \\
\hline Just listening to the lecture & 50 \\
\hline Having the professor spend more time on review & 55 \\
\hline Completing in-class assignments & 23 \\
\hline Internet research using a laptop and wireless access & 7 \\
\hline
\end{tabular}

The option of "other" was selected by four respondents between the two surveys, but no respondents listed any additional activities. In the laptop class only seven respondents selected the Internet research activity as a preferred form of in-class engagement, suggesting resistance to having personal technologies formally integrated into classroom activities.

Between both surveys, "Having the professor spend more time on review" was the most common response with fifty-five selections, while "Just listening to the lecture" was a close second with fifty responses. "Small group discussions" was the next most popular with twenty-nine responses, while "Completing inclass assignments" received twenty-three responses between the two surveys. Perhaps surprisingly, "Writing tests" was not the least popular activity having been selected by a total of seventeen respondents. 
What this question demonstrates is that there are a number of various technology-free activities that respondents would engage in in class, further contradicting the digital native argument that the education system needs to incorporate technology in order to reach and meet the needs of students. The finding that students prefer moderate amounts of technology in the classroom is supported by Palfrey and Gasser (2008) who, as discussed in the introductory chapter, agree that today's youth are digital natives, but do not agree that the education system needs to be overhauled to accommodate them. These authors argue that:

We don't need to overhaul education to teach kids who are born digital. There is a temptation among those who love technology to promote radical changes in the way we teach our students. It's easy to fetishize technology. That instinct is wrong. Learning will always have certain enduring qualities that have little or nothing to do with technology (2008:246).

The respondents in this research seem to share Palfrey and Gasser's view that there are aspects of education that are not dependent on, and do not necessarily benefit from technology.

\section{Summary}

This chapter addressed the role of technology both in the classroom and in students' education more generally. Beginning with a look at the personal technologies that respondents own, the chapter has presented the findings from a series of survey questions about educational expectations and the importance of technology. It is evident that respondents almost universally own mobile personal technologies such as laptops, $\mathrm{mp} 3$ players and cell phones, but that 
these technologies are not necessarily used as part of their education. It is also evident that respondents are very comfortable using technology. Furthermore, male and female respondents were generally consistent in their responses to the questions presented in this chapter. This suggests that while their personal experiences with using clickers and laptops were sometimes varied, gender may not be a factor regarding general expectations for the role of technology in education.

'Critical thinking' and 'information finding' were the two most important skills identified by respondents. This is interesting because according to Tapscott (2009), strong critical thinking skills are one of the defining features of members of the net generation. Tapscott argues that because today's youth spend so much time on the Internet and are so inundated by information, they have become scrutinizers and have developed "the ability to distinguish between fact and fiction" (Tapscott 2009:80). If this is the case then it is a bit curious that critical thinking and information finding are the skills respondents most want to develop in their time at university. Perhaps they want to improve on the skills they already possess, or perhaps they simply recognize that these are skills they should possess in the digital age and that they can be developed at university.

After looking at the skills and capacities that respondents hope to develop in their time as university students, technology was brought into the picture in terms of questioning its importance and uses in relation to education. The results of these survey questions have demonstrated that technology is important to respondents' education but not necessarily within the classroom. For personal 
use, communication and skill development, technology appears to be a vital part of respondents' educational experiences, but the same cannot be said for technology within the classroom. Despite the technologically mediated options, respondents appear to prefer the more 'traditional' options of listening to lectures, spending more time on review, and working with their peers in small groups.

While chapter three on clickers, and chapter four on laptops, provided some support for the digital native characterization of youth and even some support for the argument that technology (clickers but not laptops) should be further integrated into classrooms, this chapter stands in contrast to these earlier findings. Far from desiring digitally enhanced interactive classrooms where professors facilitate student-centred, random-access, and collaborative learning as advocated for by Tapscott (1998), contemporary students seem to want a combination of broadcast and interactive forms of learning where professors lecture and review, and students listen and collaborate with their peers in face-toface groups. While students may be digital natives in their social lives, and may bring their own technologies to class, they appear to be decidedly less digital when it comes to technology being formally incorporated into the classroom. They value critical thinking and interactivity as suggested by digital native theorists, but they do not necessarily want or need everything they do to be digitally mediated. 


\section{Chapter 6 The Complex Role of Technology in University Education}

The present research is a critical sociological examination of the role of technology in undergraduate university classrooms. Specifically, this research has been shaped by the question: does the characterization of youth as digital natives apply to young peoples' expectations and experience of education? In pursuing this question, two supplementary questions have been considered. First, how do students experience instructor-introduced, and learner-introduced technologies in their undergraduate classrooms? And secondly, what do students identify as the role of technology in developing the skills and capacities they hope to advance in their university education? In order to address these three interrelated questions, a mixed methods approach has been used to incorporate qualitative and quantitative data from unobtrusive observations, interviews, and in-depth surveys.

The characterization of youth as digital natives interrogated in this thesis comes from Prensky (2001a, 2001b, 2006), and Tapscott $(1998,2009)$. These authors both argue that growing up surrounded by digital technologies has defined the lives of today's youth, making them fundamentally different from previous generations. The common traits identified by Prensky (2001a) and Tapscott (2009) in their descriptions of digital natives and the net generation include desiring speed in everything they do, liking random access and customization, thriving when networked or collaborating, and wanting everything they do to be fun and entertaining. 
These authors' arguments continue by insisting that the current education system is outdated, and that educators and administrators need to change both their content and methods in order to meet the needs of a new generation of students. Both authors advocate for the increased use of technology as the most successful way to adapt the education system for digital native learners. In order to investigate the claims put forth by these digital native theorists, clickers and laptops have been used as examples of digital technologies - one institution provided and one student provided - present in undergraduate classrooms. The case of university education has been used to interrogate the digital native characterization because of the importance of education in the lives of contemporary youth, and because both Prensky (2001a, 2001b, 2006) and Tapscott $(1998,2009)$ advocate for profound changes to the education system based on their characterizations of young people.

The discussion in this chapter is organized thematically based on the findings of chapters three, four, and five, which contribute to the body of literature that critically examines the digital native theory. Each chapter focused on different technologies and drew attention to various characteristics that digital native theorists believe define today's youth. More specifically, the three data chapters shed light on the role of interactivity and collaboration in the classroom, students' comfort levels with using technology, and issues of 'play' versus 'work'. The current chapter concludes with a reflection on the contributions made by the research and makes recommendations for future research on youth, technology, and education. 


\section{The Digital Native Debate}

As accepted and utilized as the digital native characterizations of youth have become, there are criticisms of the assumptions made by digital native theorists. Much of this literature highlights the discursive and constructed nature of the digital native characterization by emphasizing its appeal to common sense. The existing critical literature is also quick to note that digital native theorists' views on youth are overly technologically deterministic, in that digital technology is attributed as the sole factor in shaping the new generation of youth (Selwyn 2009).

Another feature of the digital native debate is that it raises the question of needs. The digital native argument that the education system is outdated and should be digitally enhanced, is predicated on the preliminary argument that the current education system does not meet the needs of digital native students. Bennett et al. (2008) equate the 'digital native' with Cohen's 'moral panic' because of the way it is used by digital native theorists to advocate for profound change, in this case to the education system. The digital native student is put forth as a 'threat' to the education system, and according to digital native theorists, increasing the role of technology in both teaching methods and content is the only way to combat this threat (Prensky 2001a).

Further to the discussion of student needs, Bayne and Ross (2007) argue that what digital native theorists put forth as student needs are actually market needs, and that these 'needs' are a front for promoting a commodified vision of the education system. Sheely (2008) demonstrates how the 'digital native' has 
gone from an idea to an accepted fact, and argues that rather than fact, it is a discursive illusion. Notably though, Sheely (2008) argues that while the digital native theorists may not be correct about the digital origins of students' needs, the 'digital native' is an important illusion insofar as it provides a starting point for a discussion on the learning needs of contemporary students. Congruent with Shelly's (2008) argument, the present research has used the digital native 'illusion' as a starting point for an interrogation of students' experience and expectations of their university education. The empirical evidence presented in the current research supports a critical reading of digital native theory by demonstrating that, while technology is very much present in the lives of young people today, they do not necessarily require technology to be present in their education.

The final argument put forth to counter the digital native characterization of youth is that it is too simplistic. Numerous authors argue that there is a great deal of within-group difference amongst the so called digital natives and that these differences could be more important than the similarities (Bennett et al. 2008; Jones et al. 2010). They also note the importance of context and that demonstrating digital native characteristics in one aspect of life might not translate to others. All of these authors who have advanced critical readings of the 'digital native' argue that more empirical evidence is needed to further interrogate the digital native characterization of youth.

The present research is aligned with, and demonstrates support for these digital native counter-arguments. The findings suggest that there is within-group 
difference in terms of the ways in which technology is used by students and the importance they place on it. The findings also demonstrate support for the importance of context insofar as the almost universal ownership of digital technologies by respondents lends support to the digital native argument, however the ownership of personal technologies does not universally translate to the classroom.

It is evident from the research findings that digital technologies have a large presence in the lives of modern students, but there also appears to be recognition that technologies should be used with a purpose and not for their own sake. The current research demonstrates that today's youth desire only a moderate amount of technology to be incorporated into the classroom and that they are largely in favour of increased levels of socially mediated classroom activities such as more lecture and review, and small group discussions with their peers. These findings stand in sharp contrast to the digital native argument that educational methods and content need to be altered to centre around the use of digital technologies.

Many of the characteristics identified by Prensky and Tapscott may be applicable to today's youth, but these theorists may have been too quick in associating these characteristics with the presence of digital technologies. The results of the research suggest a much more complex relation to digital technologies than the cause and effect relationship put forth by Prensky and Tapscott. In particular, three digital native themes have been reconsidered in light of the findings of the present research. 


\section{Interactivity and Collaboration}

According to digital native theorists, modern students thrive on interactivity and collaboration because they have become accustomed to it in their everyday digital lives primarily through the use of the Internet, and video games (Prensky 2001a). This research supports the identification of students' desires for interactivity and collaboration in their educational experiences. However, as demonstrated by students' survey responses, these features do not necessarily have to be digitally mediated.

In the clicker portion of the research, for example, students are generally in favour of the use of clickers. These digital technologies are specifically designed to support and encourage interactivity in the classroom. Clickers allow for technological interaction by making it possible for students to use remote devices to respond to questions throughout a PowerPoint presentation, and then presenting the results to the entire class instantaneously. However, through the observation of two clicker-enabled classes, it is seen that beyond this technological interaction, the use of clickers facilitates social interactions within the classroom both between students and their peers, and between the professor and students. When asked about the level of technology they would like to have present in the classroom, respondents from the clicker classes were most likely to respond that they like the use of PowerPoint with clickers. The response to this question suggests that they like the overall classroom experience that clickers facilitate. 
In the laptop classes, interactivity is also present though it is manifest in a different way. More specifically, the interactivity that is present in the laptop classes seemed to take place between individual students and their personal technologies such as laptops and cell phones. Laptops are dynamic digital technologies that offer users the ability to engage in a variety of activities simultaneously. Based on the results of the laptop surveys, students want the freedom to bring their laptops to class with them but they are much less in favour of having laptops incorporated into the formal lecture proceedings. In contrast to clickers which are used to interact with the lecture, laptops do not appear to offer options for social interaction within the classroom. Unless, as suggested by Lindroth and Bergquist (2010), students are using instant messaging to communicate with their peers about the lecture as it is taking place.

When asked about the activities students would like to engage in while in class, one of the most commonly selected responses is "small group discussions". This supports the digital native argument that students desire collaboration, but it is a decidedly non-digital form of collaboration. This is an important finding because it simultaneously supports and contradicts digital native theory, by suggesting that while contemporary youth may desire collaboration, it may not be a causal result of growing up with digital technologies as digital native theory suggests. Perhaps the desire for small group discussion is indicative of a desire for less technology, not more. It is possible that because digital technologies are so omnipresent in the lives of students that they may seek out and welcome opportunities to engage in face-to-face social interactions. 


\section{Comfort with Technology}

When asked directly about their level of comfort with technology, the majority of respondents reported that they are 'comfortable' or 'very comfortable' with using technology. This supports the basis for the digital native argument, but it is important to note that there are also respondents who reported that they are 'very uncomfortable' with using technology meaning that comfort with technology is not universal amongst respondents. Interestingly though, despite the varying levels of comfort, respondents almost universally own computers (either desktops or laptops), cell phones, and to a slightly lesser degree, mp3 players. This suggests that, at least in their personal lives, respondents experience high levels of digital technology saturation. However, given their universality, ownership of these mobile technologies may be demonstrative of a broader societal trend as opposed to being a feature unique to youth9.

While respondents seem to be comfortable with technology in their personal lives, the situation in the classroom appears to be a bit different. Respondents demonstrate that they prefer a moderate level of technology to be integrated into their classrooms. More specifically, respondents seem to be comfortable with the status-quo. In both surveys, the majority of respondents said that in terms of the level of technology they would like to experience in class, they like what they are used to - lectures with PowerPoint and clickers in the clicker classes, and lectures with PowerPoint in the laptop classes. Perhaps then, with

\footnotetext{
9 In the laptop classes, the three respondents who were older than the digital native age range demonstrated similar levels of technology ownership and comfort compared to their younger counterparts.
} 
the simple addition of PowerPoint and possibly clickers, the 'traditional' classroom experience that digital native theorists are so critical of, may not be so lacking after all.

The findings also contradict the digital native argument that educators today are not comfortable or familiar with the use of technology. This could not be further from the truth for the two professors who were interviewed as part of the clicker portion of the research. While these professors said they are hesitant to use clickers again, it is not because they are uncomfortable using the technology. On the contrary, these professors demonstrate high levels of proficiency with using technology, and it appears to be the fact that clickers cannot currently be "seamlessly" integrated into their lectures that causes this hesitation. Their comfort with technology seems to lead to high expectations for technology and these expectations may not have been met by the clicker system. While these two professors cannot be assumed to represent all professors, their experiences do go a long way in questioning the digital immigrant characterization of educators. And, by questioning the digital immigrant characterization of educators, the digital native characterization of youth is further questioned insofar as the digital native argument is premised on the discontinuity between students' and educators' utilization of digital technologies. If both students and educators demonstrate similar levels of comfort with, and utilization of, digital technologies, then digital technologies cannot be assumed as the cause of generational differences that are present. 


\section{'Play' versus 'Work'}

The final theme that is present throughout the research is the play/work dichotomy. This dichotomy is put forward by digital native theorists as one of the primary reasons for the need of the education system to be digitally upgraded. Their argument is that because today's youth are so accustomed to fun in their daily lives due to their interactions with digital technologies, school needs to be made more fun as well (Prensky 2001a; Tapscott 1998).

Clickers seem to support the argument that classrooms should be made more fun through the integration of technology because of their game show-like features. Students are generally in favour of using clickers which could be related to their game-like qualities. Bringing personal technologies into the classroom tells a different story however. Prensky (2006) argues that one of the ways that education can be made more fun is through the integration of students' personal technologies such as their cell phones, but the findings in the present research suggest otherwise.

It was observed, that many students utilize their personal laptops, cell phones and $\mathrm{mp} 3$ players for non-academic and entertainment purposes while in class. However, when asked on the laptop survey if they would like to have their laptops incorporated into the lecture there was very little support for this activity. The response to this question suggests that while students say they want laptops and wireless Internet to be available to them in their classrooms, they are resistant to having their personal entertainment technologies commandeered for educational or 'work' purposes. They do not appear to want their personal 
technologies used to make learning activities more fun but instead appear to want to maintain some boundaries between play and work activities. The clicker and laptop surveys did not directly address the issue of fun so it is difficult to know for certain how respondents feel about how fun their classes are, or whether technology can make classrooms and lectures more fun.

\section{Research Contributions}

A unique contribution of this research is that it has been conducted by a digital native aged researcher. This is important, because most work and theorizing about digital natives has been done by non-natives. Tapscott's (1998, 2009) work does include hearing from youth, but it is essentially conducted by an adult, looking at and defining youth. In contrast to Prensky, Tapscott, and others who have researched the digital native claims, I fall into the digital native category and am only recently removed from being an undergraduate student. Furthermore, if I was to respond to the surveys used in this research, or be observed in a classroom setting, my responses and actions would likely mirror those presented in the research findings. I would report being comfortable using technology, and that I rely on my laptop and wireless Internet access to conduct the vast majority of my educational activities. My many similarities to the participants has made me more acutely aware of the diversity within the generation of youth involved in the research, which has influenced my critical reading of the digital native theory interrogated by the research. Engaging in this research has also allowed me to critically reflect on my own relationship with digital technologies. 
Additionally, very little research has been done on the use of either clickers or laptops in university classrooms, so while these two technologies have served as the means through which the general role of technology in university education can be interrogated, this research has also contributed empirical data on the use of these two digital technologies in particular. Even less has been done to look at the presence of these technologies from a sociological perspective and the present research has been an attempt to fill in some of these missing pieces by exploring the use of these two distinct digital technologies from the perspective of students. Both of these technologies have been found to have important presences in university classrooms by impacting the types of interaction and activities that take place.

Furthermore, as indicated by those who have contemplated the digital native characterization of youth, there is a general lack of empirical research in this area. Evidence is lacking to either support or question digital native theories on youth and education and the present research contributes some of this much needed evidence. The findings of this research have, at the very least, further complicated the digital native debate by providing some support for the digital native characterization while at the same time questioning its technological determinist definition of youth.

Lastly, it is hoped that by participating in this research, students may have taken the time to critically examine their relation to technology and the role that it plays in their educational experience. This is not to say that technology is bad, but rather that because it is so ubiquitous, its presence and use can often go 
unexamined. It is important to gain an understanding of how technology can both help and hinder day-to-day activities such as, in the case of undergraduate students, attending lectures and participating in class.

\section{Future Research}

The present study contributes some much needed empirical research to the digital native debate but there is still more research to be conducted in this area. While it was an initial goal of the research to involve students in focus groups to discuss the role of technology in their educational experiences, this was not possible. Future research on technology and education should make it a priority to hear from students since they are the subjects who have been defined by others as digital natives.

In terms of the use of clickers in undergraduate classrooms, more should be done to look at how they can be used in social science and humanities classes. Most of the existing research on clickers, the present research included, has looked at their use in subjects that involve concrete facts as opposed to theory and interpretation. Research should be done to see if clickers can be successfully implemented in these settings. Further research should also be done to look at the impact of clickers on students' learning outcomes.

Most of the research that has been done on laptop use in university has been conducted in settings where students are provided with laptops by the institution. Very little has been done on the impact of students bringing their own laptops to class with them. This thesis provides a starting point for this area of research but there is more to be done, especially in terms of the impact that 
laptop use has on student success. More can also be done to investigate if there are ways in which students would like to have their laptops integrated into lecture proceedings.

Further research on digital native theory should also look at whether or not it has had an impact on educational policy. This was beyond the scope of the present research, but given that digital native theorists advocate for profound changes to the education system, it is an important area of consideration. More research should also be conducted on the reasons for the within-group differences that were identified in the research, including the impact of technology on the teaching and learning of different subject areas, and potential reasons for gender differences in relation to technology in classrooms. Lastly, longitudinal research should be undertaken to further refine the understanding of how technology impacts students' educational expectations and experiences. 


\section{Appendix A \\ Letters of Information and Consent}

\section{Carleton}

UNIVER S I T Y

\section{Dear Carleton Student,}

My name is Erin Murphy and I am a Master's student in Sociology at Carleton University. This letter is an invitation to participate in my thesis research entitled Ask the Audience: Students' perspectives on the role of technology in their university education. My thesis is being supervised by Dr. Janet Siltanen in the Department of Sociology. Our contact information can be found near the end of this letter.

The purpose of my research is to hear from students about their experiences with technology in an educational setting. As part of this research I am conducting a survey and focus groups in order to hear from students about their experiences with different technologies that are being used in classrooms.

There are two ways in which you can participate in my research. First, I am asking that all students in the class take a brief on-line survey about their experience with the use of laptops in the classroom. Your responses to this survey will remain anonymous. The online survey is being made available through the American website surveymonkey.com. This means that any responses to the survey are subject to the Patriot Act. Under the Patriot Act legal authorities in United States have the right to access the personal information and computer addresses of respondents.

Secondly, I am asking that students volunteer to participate in a small focus group that will allow for a more detailed discussion of the use of technology in the classroom. The focus group will last approximately one (1) hour and will be made up of eight (8) to ten (10) students from this course. Due to the nature of a focus group, your participation in the group would not be anonymous within the group, but individuals will not be identified in my final report. The focus group will be audio recorded so that I can included students' thoughts in my thesis. To volunteer for the focus group simply contact me via the email address provided at the end of the on-line survey. If you are chosen for the focus group you will have to sign an additional consent form stating that you agree to participate in the group and to respect the opinions of the other focus group participants. I will have no means of connecting survey responses to focus group participants.

My research is in no way connected to your course and participation in the survey and/or focus group will have no impact on your course grade. The professor will not have direct access to the survey results or the focus group 
transcripts and they will only have limited access to the research findings after final grades are submitted. I will be the only person with access to the raw data. You may withdraw from the study at anytime. However, should you decide to withdraw from the focus group any data you have provided prior to your withdrawal will remain.

The survey results will be stored in a password-protected secure database and the audio recordings and transcripts from the focus groups will be locked away in my house. My thesis will be finished by September 2010 at which point you can contact me (emurphy4@connect.carleton.ca) to see a copy of the final report.

Even if you do not wish to participate in the focus group, I ask that you please take a few minutes to fill out the on-line survey.

If you have questions about any part of this project please direct your questions to:

\author{
Erin Murphy \\ MA Candidate, \\ Department of Sociology \\ Carleton University \\ emurphy4@connect.carleton.ca \\ $613520-2582$ \\ Dr. Janet Siltanen \\ Professor, \\ Department of Sociology \\ Carleton University \\ janet_siltanen@carleton.ca \\ $613520-2582$
}

This research has been reviewed and received ethics clearance by the Carleton University Research Ethics Committee. If you have concerns or questions about being involved in this study you can contact the ethics committee chair. The chair's name and contact information is as follows:

Professor Antonio Gualtieri, Chair

Carleton University Research Ethics Committee

Office of Research Services

Carleton University

1125 Colonel By Drive

Ottawa, Ontario K1S 5B6

Tel: 613-520-2517

E-mail: ethics@carleton.ca

Thank you for considering participating in my research. 


\section{Carleton}

UNIVERSITY

Consent to participate in a focus group on the use of laptops in the classroom

I, (print name) have read the above letter and understand that I am participating in a research project and I voluntarily agree to participate. By agreeing to participate I agree to respect the opinions of the other focus group participants and to maintain the confidentiality of the focus group discussion. I understand that I can leave the focus group at any time but that I cannot withdraw any data I provide prior to withdrawing.

Participant's Signature

Date

Researcher's Signature

Date

Contact Information:

Erin Murphy

MA Candidate,

Department of Sociology

Carleton University

emurphy4@connect.carleton.ca

$613520-2582$

or

Dr. Janet Siltanen

Professor,

Department of Sociology

Carleton University

janet_siltanen@carleton.ca

$613520-2582$ 
Consent to participate in an interview about the use of educational technologies

I, (print name) understand that I am participating in a research project and I voluntarily agree to participate. I understand that this interview is being audio recorded and that the researcher is the only person who will have access to the recording and written transcripts of this interview. I understand that I will not be identified in the final report and that I can withdraw from the interview at any time.

Participant's Signature

Date

Researcher's Signature

Date

Contact Information:

Erin Murphy

MA Candidate, Department of Sociology

Carleton University

emurphy4@connect.carleton.ca

613 520-2582

or

Dr. Janet Siltanen

Professor,

Department of Sociology

Carleton University

janet_siltanen@carleton.ca

$613520-2582$ 
Appendix B

Clicker and Laptop Surveys
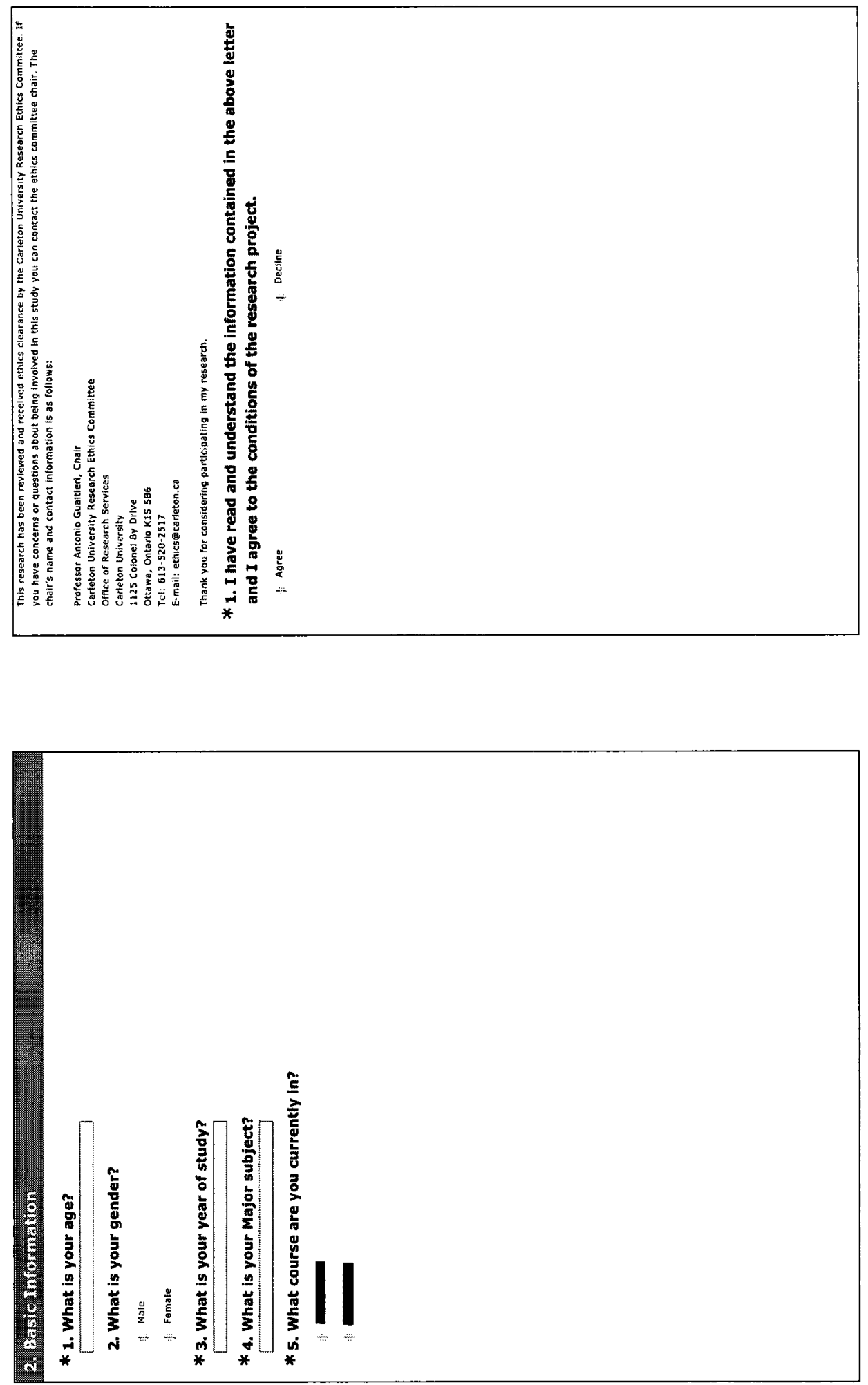
988
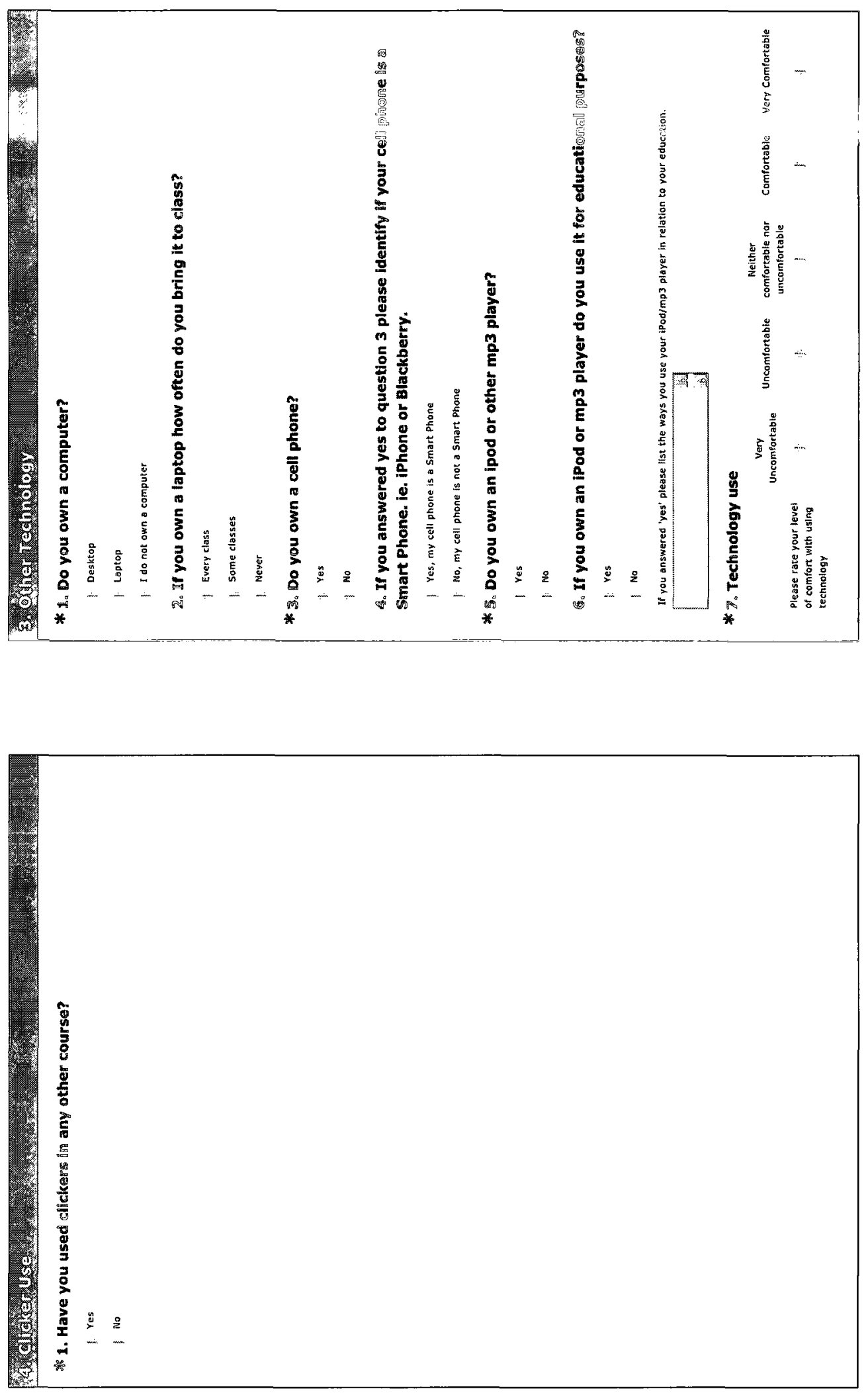


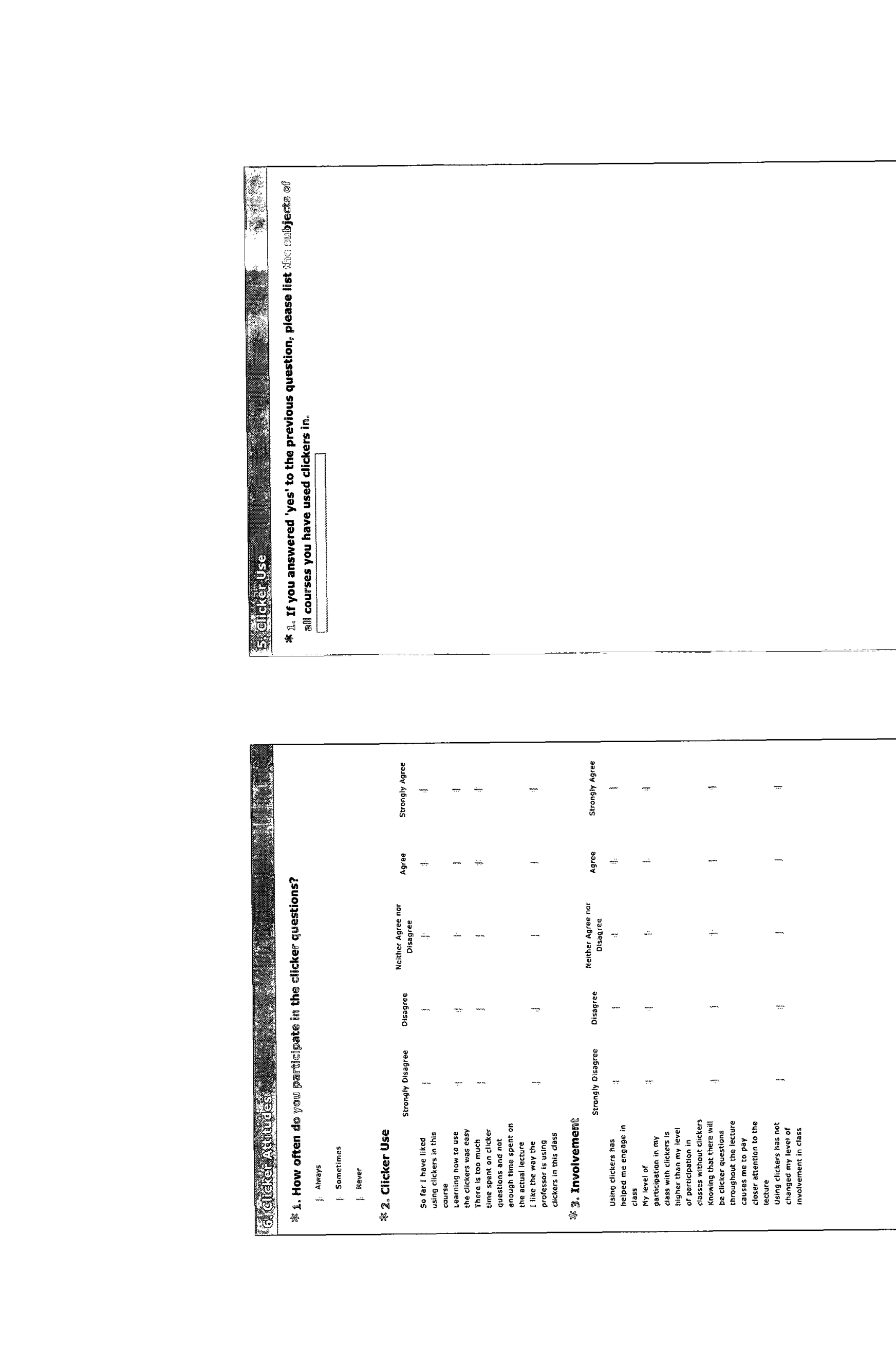



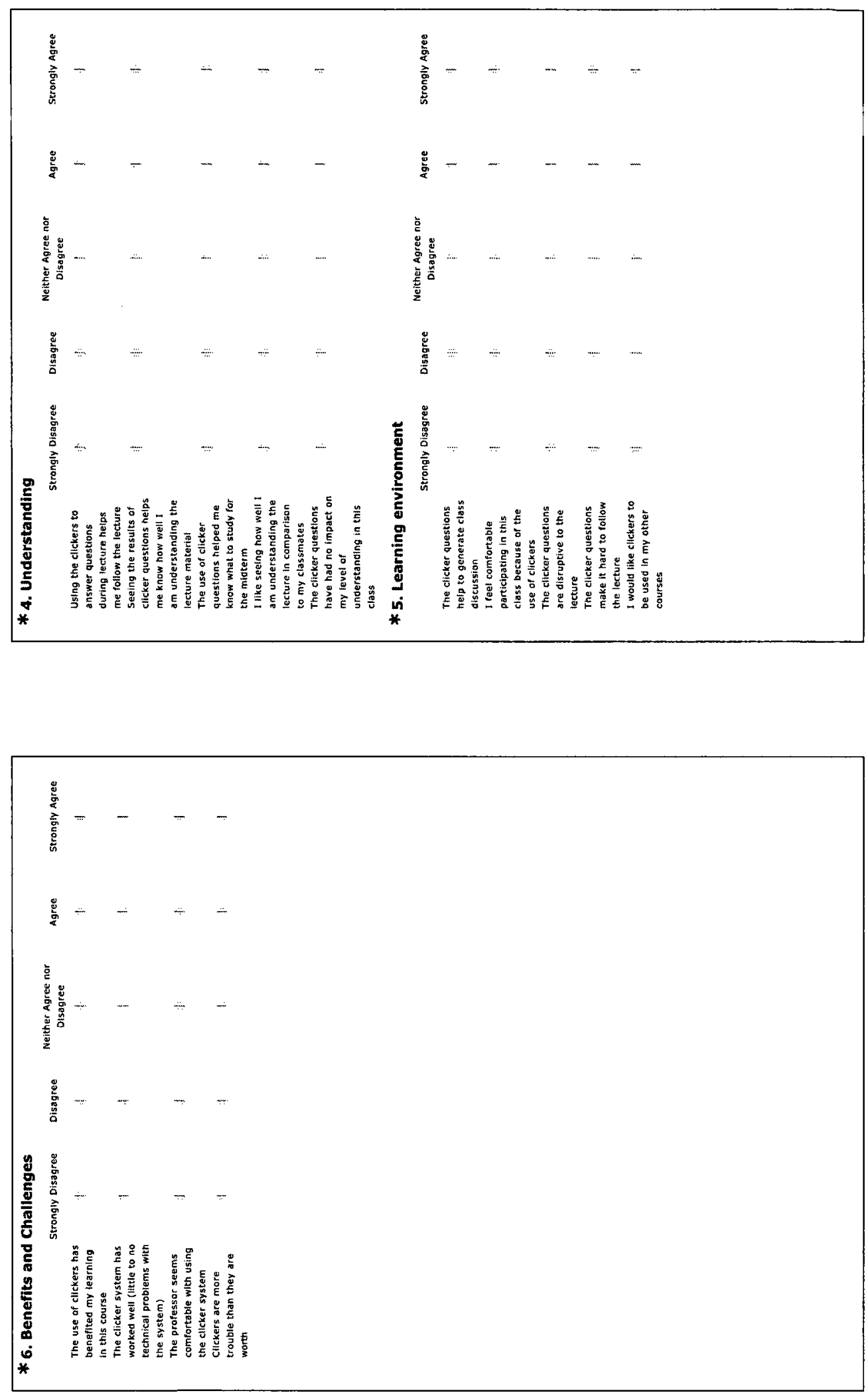

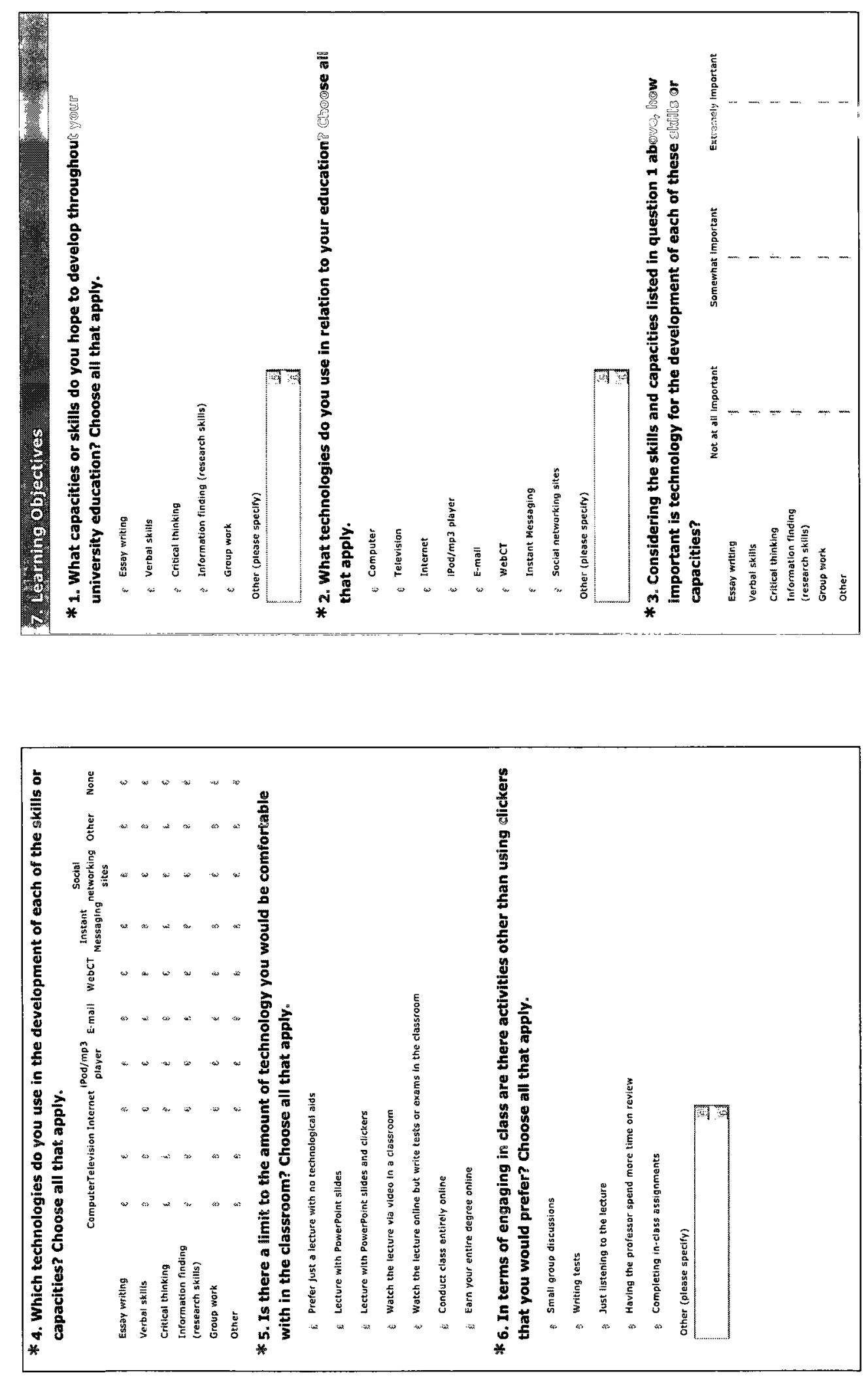


$$
1
$$



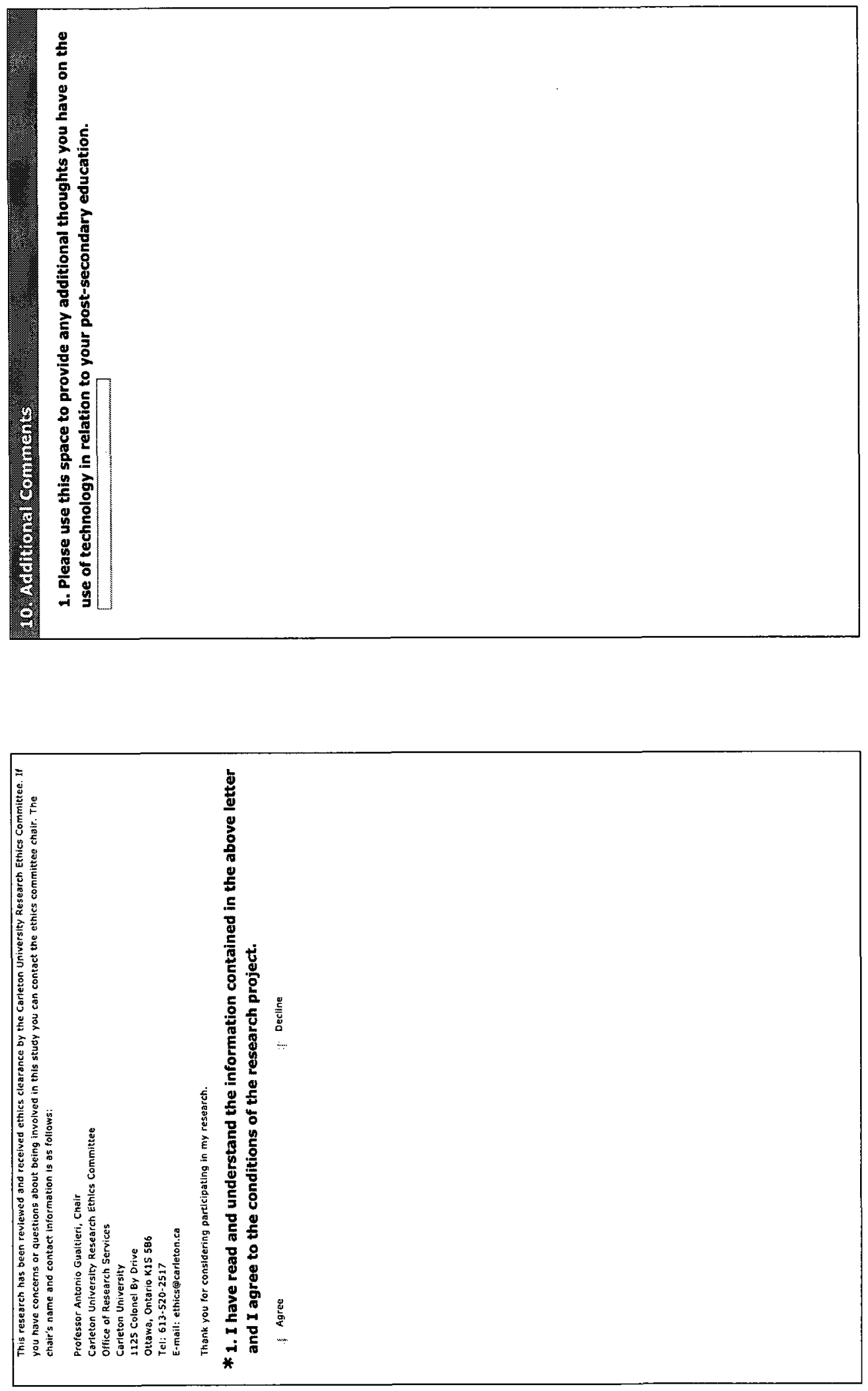

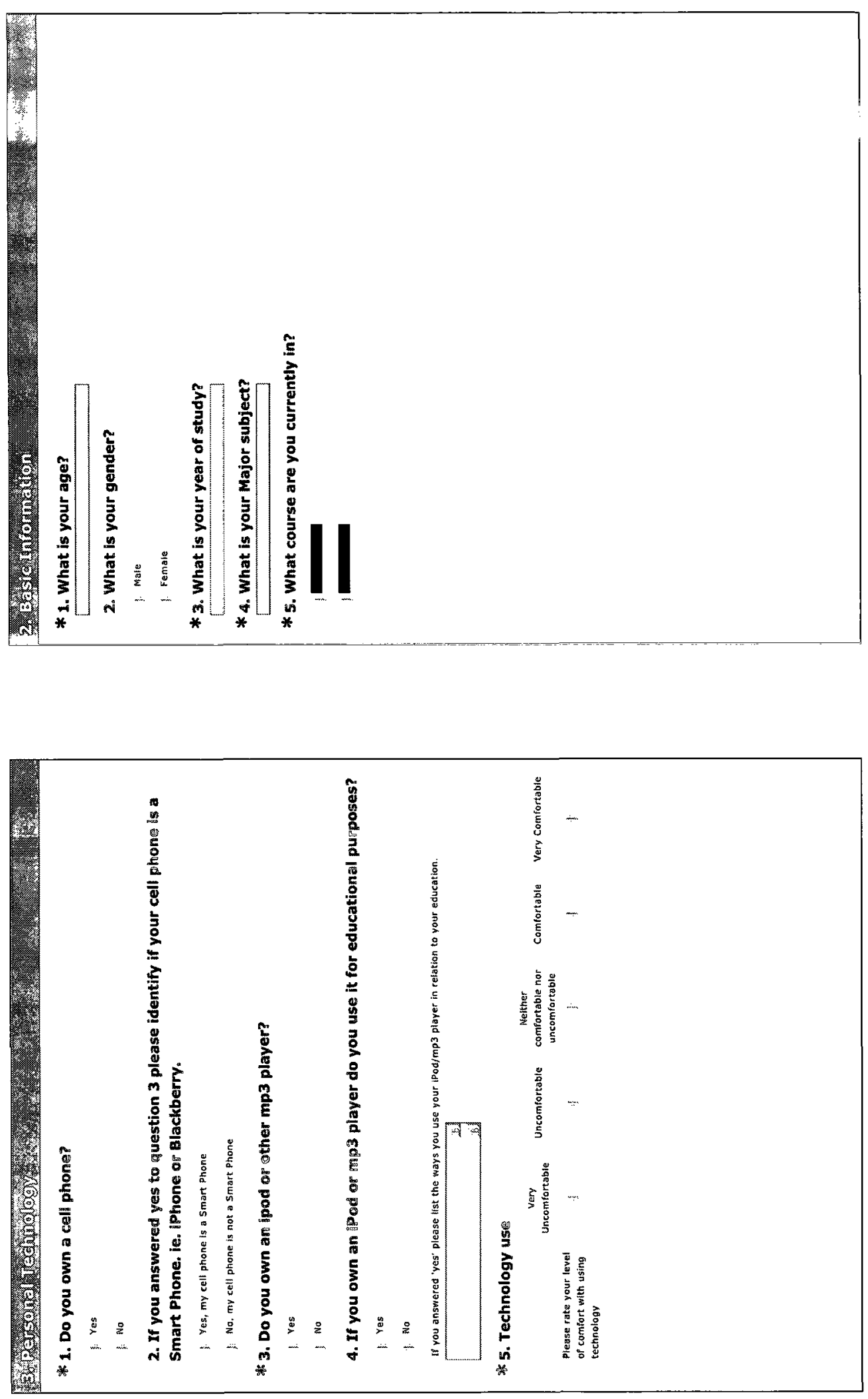

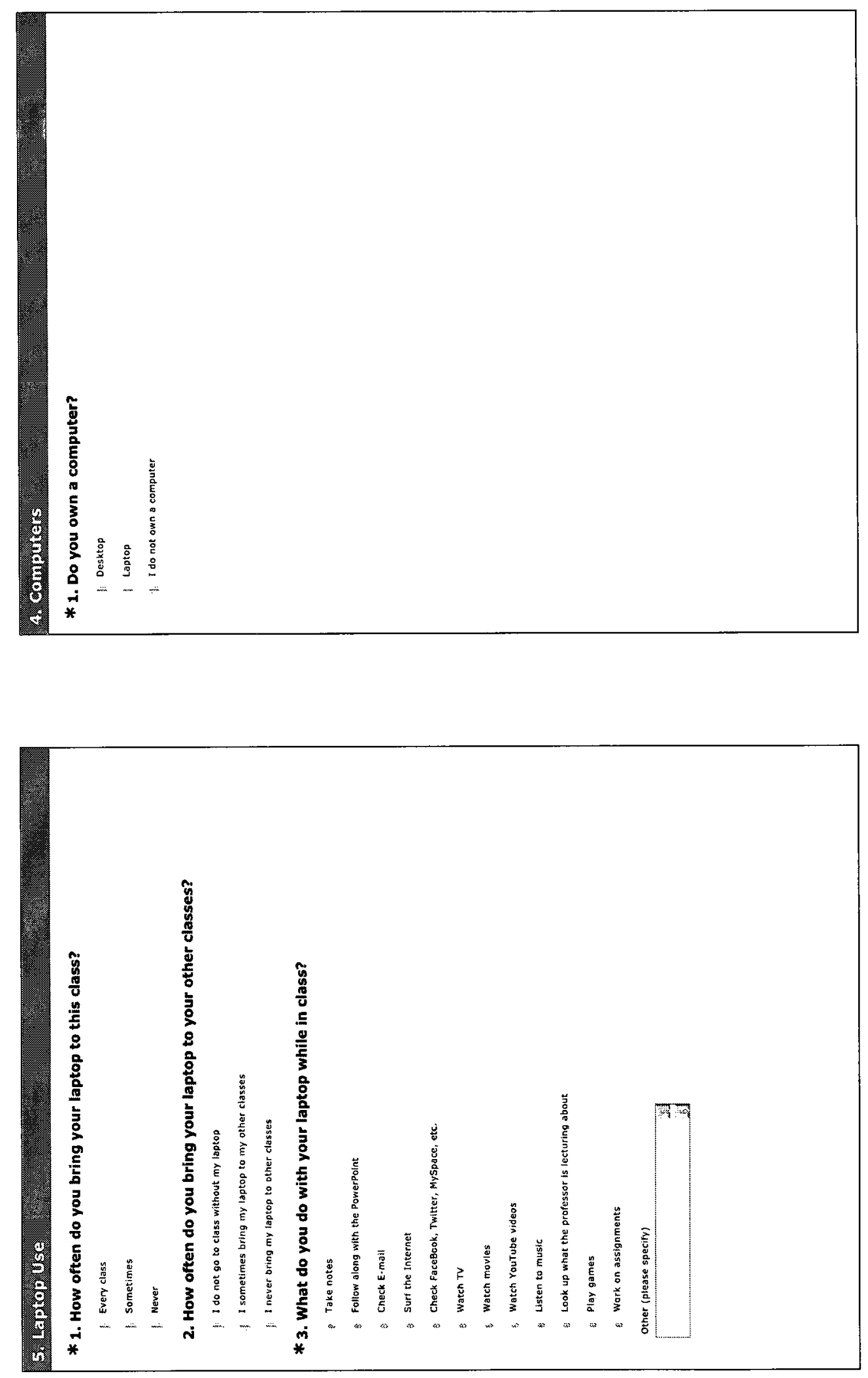

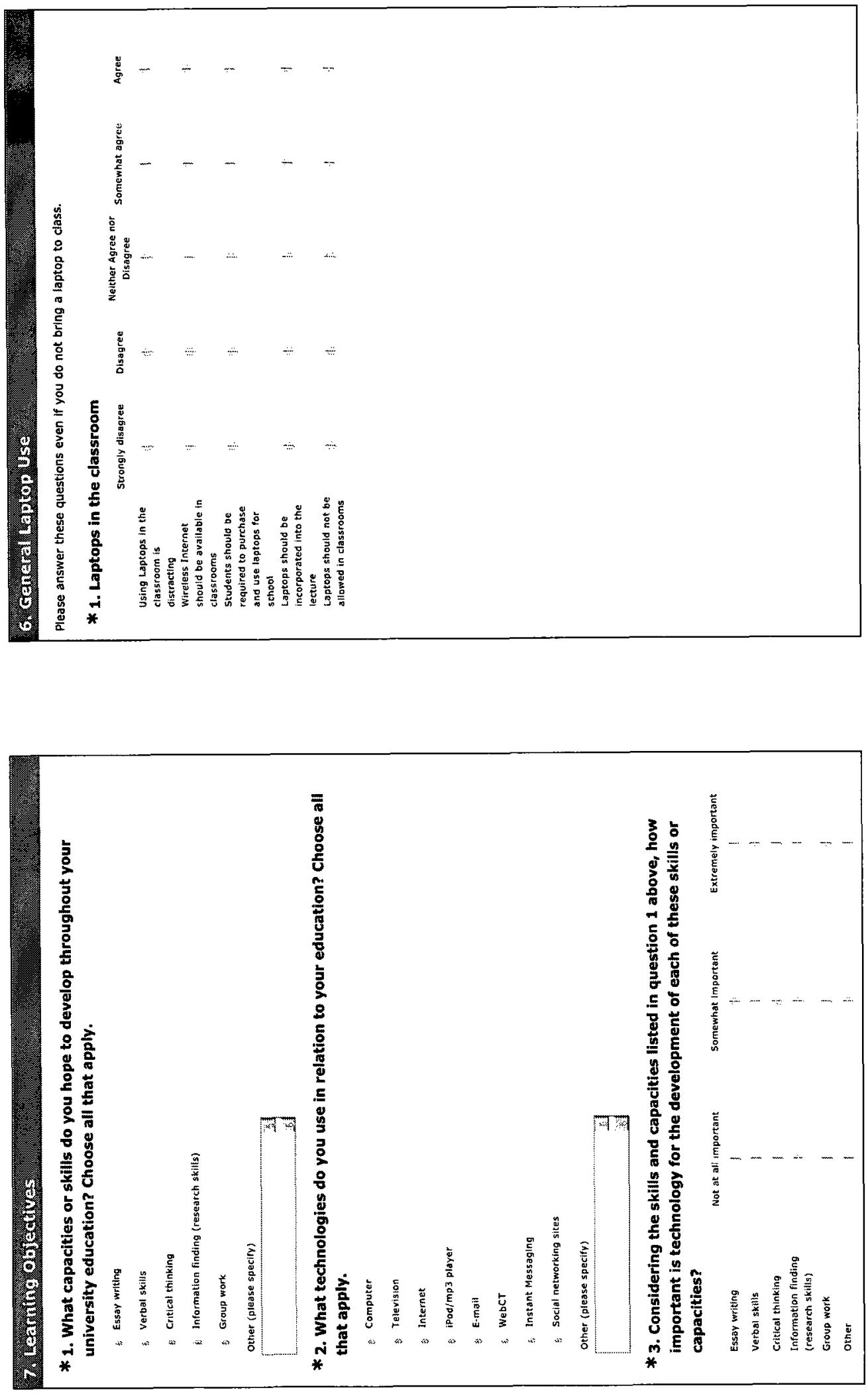


$$
\frac{1}{1}
$$




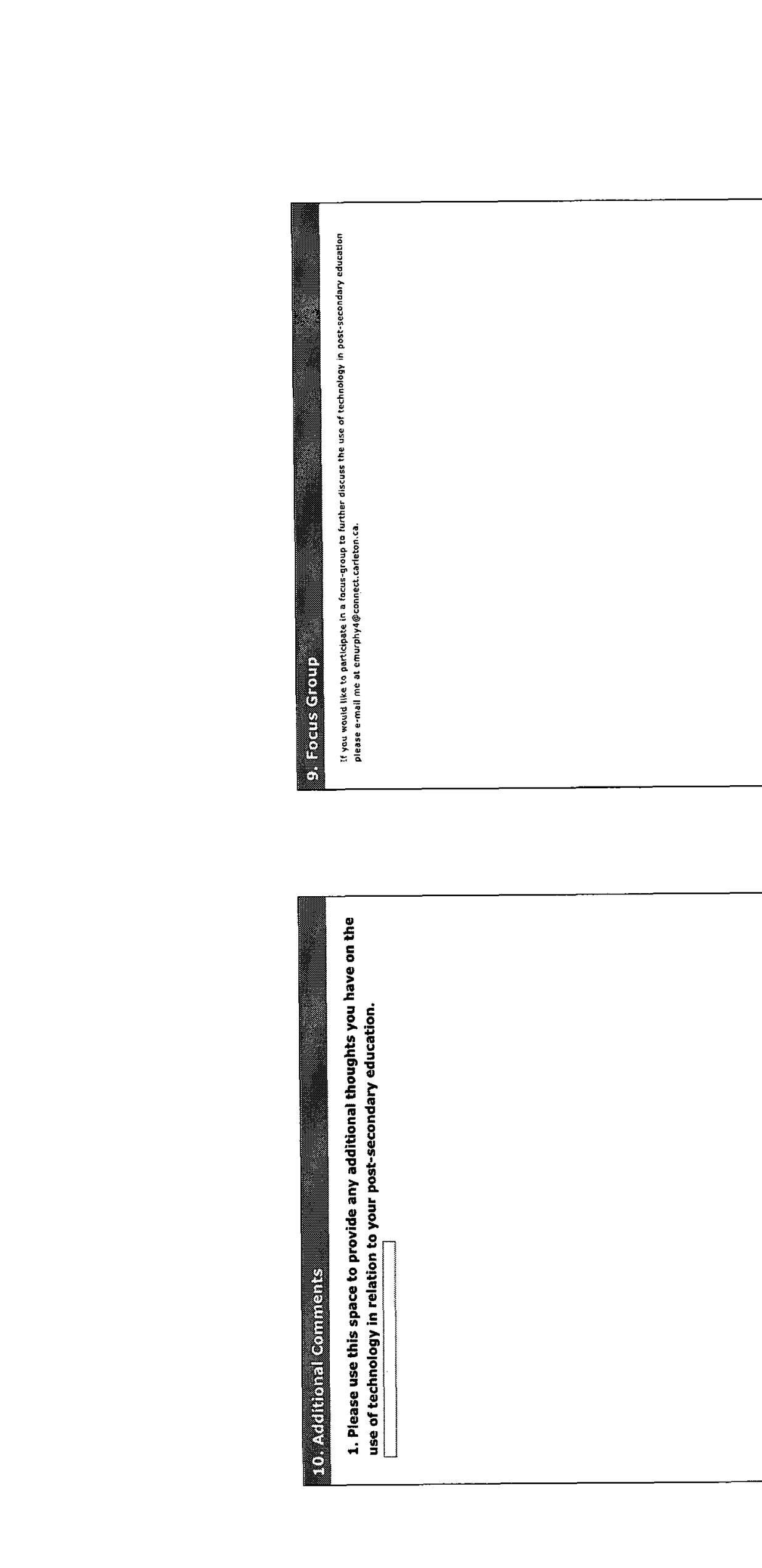




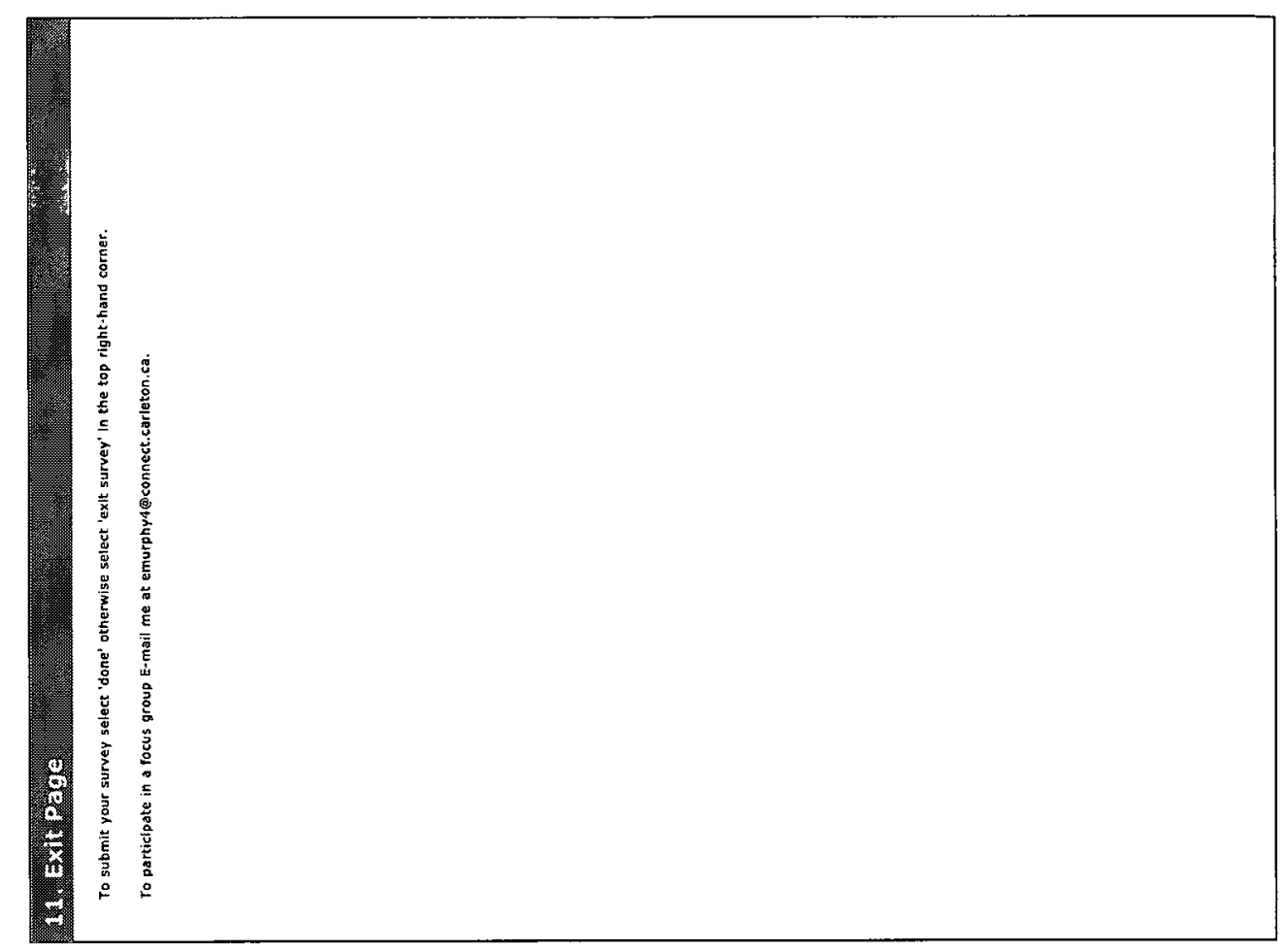




\section{Appendix C \\ Clicker Interview Questions}

1. Why did you want to incorporate clickers into your teaching?/ What are your reasons for using clickers?

2. How did you first become aware of clickers? (Did you learn about them on your own or were they introduced to you by the university?)

3. Have you noticed any changes (either positive or negative) in your class that you would attribute to the use of clickers? (changes such as attendance, grades, classroom atmosphere, participation levels?)

4. Have you heard from students at all about using clickers?

5. What other technologies do you use in your teaching?

6. Are there other technologies you would like to be using/ hope to use in the future?

7. Have you encountered any problems while using clickers?

8. Is there anything you would like to add? 


\section{References}

Bayne, Siân, and Jen Ross. 2007. "The 'digital native' and 'digital immigrant': A Dangerous Opposition." Paper presented at the Annual Conference of the Society for Research into Higher Education (SRHE).

Bennett, Sue, Karl Maton, and Lisa Kervin. 2008. "The 'digital native' debate: A critical review of the evidence." British Journal of Educational Technology 39: 775-786.

Brannen, Julia. 2005. "Mixing Methods: "The Entry of Qualitative and Quantitative Approaches into the Research Process." International Journal of Social Research Methodology 8(3): 173-184.

Bryman, Alan, Saul Becker, and Joe Sempik. 2008. "Quality Criteria for Quantitative, Qualitative and Mixed Methods Research: A View from Social Policy." International Journal of Social Research Methodology 11(4): 261-276.

Chickering, Arthur W., and Zelda F. Gamson. 1987. "Seven Principles for Good Practice in Undergraduate Education." Retrieved August 17, 2009 http://www.nnmc.edu/academics/assessment/documents/ sevenprinciples.pfd

Cutrim Schmid, Euline. 2008. "Using a Voting System in Conjunction With Interactive Whiteboard Technology to Enhance Learning in the English Language Classroom." Computers \& Education 50: 338-356.

Dunderstadt, James J., Daniel E. Atkins, and Douglas Van Howling. 2002. Higher Education in the Digital Age: Technology Issues and Strategies for American Colleges and Universities. Westport, CT: Praeger Publishers.

Dutton, William H., and Brian D. Loader, eds. 2002. Digital Academe: The New Media and Institutions of Higher Education and Learning. London: Routledge.

Fox, Jezz, Craig Murray, and Anna Warm. 2003. "Conducting Research using Web-based Questionnaires: Practical, Methodological, and ethical considerations." International Journal of Social Research Methodology 6(2): 167-180.

Fried, Carrie, B. 2008. "In-class Laptop Use and its Effects on Student Learning." Computers and Education 50: 909-914.

Hoffman, Christina, and Susan Goodwin. 2006. "A Clicker For Your Thoughts." New Library World 107(1228/1229): 422-433. 
Jones, Sandra, Deborah Henderson, and Pamela Sealover. 2009. '“Clickers' in the Classroom." Teaching and Learning in Nursing 4: 2-5.

Jones,Chris, Ruslan Ramanau, Simon Cross, and Graham Healing. 2010. "Net Generation or Digital Natives: Is There a Distinct New Generation Entering University?" Computers and Education 54: 722-732.

Kay, Robin H. 2009. "Examining Gender Differences in Attitudes Toward Interactive Classroom Communications Systems (ICCS)." Computers \& Education 52: 730-740.

Kay, Robin H., and Ann LeSage. 2009. "Examining the benefits and challenges of using audience response systems: A review of the literature." Computers \& Education. 53: 819-827.

King, Samuel O., and Carol L. Robinson. 2009. "'Pretty Lights' and Maths! Increasing Student Engagement and Enhancing Learning Through the Use of Electronic Voting Systems." Computers \& Education 53: 189-199.

Lindroth, Tomas, and Magnus Bergquist. 2010. "Laptops in an Educational Practice: Promoting the Personal Learning Situation." Computers and Education 54: 311-320.

Long, Jonathan, and Jon Dart. 2001. "Opening-up: Engaging People in Evaluation." International Journal of Social Research Methodology 4(1): 71-78.

Mauthner, Natasha S., and Andrea Doucet. 2003. "Reflexive Accounts and Accounts of Reflexivity in Qualitative Data Analysis." Sociology 37(3): 413-431.

Mayer, Richard E., et al. 2009. "Clickers in College Classrooms: Fostering Learning With Questions Methods in Large Lecture Classes." Contemporary Educational Psychology 34: 51-57.

McMahon, Mark, and Romana Pospisil. 2005. "Laptops For a Digital Lifestyle: Millennial Students and Wireless Mobile Technologies." Ascilite 421-431.

Onwuegbuzie, Anthony J., and Nancy L. Leech. 2005. "On Becoming a Pragmatic Researcher: The Importance of Combining Quantitative and Qualitative Research Methodologies." International Journal of Social Research Methodology 8(5): 375-387.

Palfry, John, and Urs Gasser. 2008. Born Digital: Understanding the First Generation of Digital Natives. New York, NY: Basic Books. 
Prensky, Marc. 2001a. "Digital Natives, Digital Immigrants Part 1." On the Horizon 9(5): 1-6.

Prensky, Marc. 2001b. "Digital Natives, Digital Immigrants Part 2: Do They Really Think Differently?" On the Horizon 9(6): 1-6.

Prensky, Marc. 2006. "Listen to the Natives." Educational Leadership 63(4): 8-13.

Selwyn, Neil. 2009. "The Digital Native - Myth and Reality." Aslib Proceedings: New Information Perspectives. 61(4): 364-379.

Sheely, Stephen. 2008. "Latour Meets the Digital Natives: What Do We Really Know." Hello! Where are you in the landscape of educational technology? Proceedings ascilite Melbourne 2008. http://www.ascilite.org.au/conferences/melbourne08/procs/sheely.pdf

Tapscott, Don. 1998. Growing Up Digital: The Rise of the Net Generation. New York, NY: McGraw-Hill.

Tapscott, Don. 2009. Grown Up Digital: How the Net Generation is Changing Your World. New York, NY: McGraw-Hill.

Toledo, Cheri A. 2007. "Digital Culture: Immigrants and Tourists Responding to the Natives' Drumbeat." International Journal of Teaching and Learning in Higher Education. 19(1): 84-92. 